Journal of Educational

and Psychological Sciences

Volume (5), Issue (25): 30 Jul 2021

P: 130 - 169

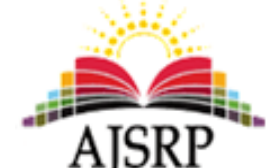

AJSRP

ISSN: 2522-3399
مجلة العلوم

التربوية والنفسية

المجلد (5)، العدد (25): 30 يوليو 2021 م

ص: 130 - 169

\title{
The interaction between support patterns and visual design methods in an electronic training environment and its impact on developing skills for
} digital content production enhanced for the hearing-impaired and the trend towards digitalization among teachers with special needs

\author{
Reham Hassan Mohamed Tolba \\ College of Technology || Ministry of Higher Education and Scientific Research || Egypt
}

Tariq Abdel Moneim Abdel Fattah Hegazi

Faculty of Educational Studies || Egyptian University for National E-Learning || Egypt

\begin{abstract}
The aim of the current research is to measure the interaction between support patterns and visual design methods in an electronic training environment and its impact on developing the skills of digital content production enhanced for the hearing-impaired and the trend towards digitization. The hearing impaired) numbering 60 teachers and teachers, they were divided according to the visual design method, 30 teachers fixed visual design method, and then divided into two groups, according to the educational support pattern based on the support pattern (informational 15 teachers- the procedural 15 teachers), 30 teachers design style Visual animation, they were divided into two groups, according to the type of support based on support (informational 15 teachers- procedural 15 teachers), and the two researchers prepared the following research tools (achievement test related to the content presented- the trend towards digitalization scale- product evaluation card for digital content enhanced for the disabled. Audio), and one of the most important findings of the research is the positive impact of using support patterns and visual design methods with an electronic training environment and the integration between the high level of cognitive achievement and the high level of The techniques for producing enhanced digital content for the hearing-impaired, and the research recommends the importance of focusing on performance skills to train teachers with special needs and note their implementation because of their importance to them after that. In training the hearing-impaired students on the use of appropriate interaction tools in augmented reality-based learning to obtain electronic learning that is commensurate with their learning characteristics.
\end{abstract}

Keywords: Patterns of electronic support, visual design, enhanced digital content, the trend towards digitization, students with hearing impairments.

$$
\begin{aligned}
& \text { التفاعل بين أنماط الدعم وأسـاليب التصيميم البصري ببيئة تدريب إلكتروني } \\
& \text { وأثره في تنمية مهارات إنتاج المحتوى الرقمي المعزز للمعاقين سمعياً والاتجاه } \\
& \text { نحو الرقمنة لدى معلمي ذوي الاحتياجات الخاصية } \\
& \text { رهام حسن محممد طلبه } \\
& \text { الكلية التكنولوجية || وزارة التعليم العالي والبحث العلهي || مصر مهر } \\
& \text { طارق عبد المنعم عبد الفتاح حجازى }
\end{aligned}
$$


كلية الدراسات التربوية || الجامعة المصرية للتعلم الإلكتروني الأهلية || مصر

المستخلص: هدف البحث الحالي الى قياس التفاعل بين أنماط الدعم وأساليب التصميم البصري ببيئة تدريب إلكتروني وأثره في تنمية

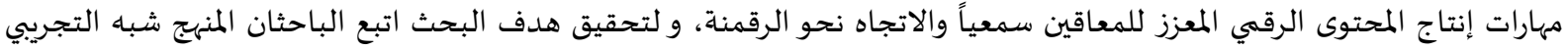

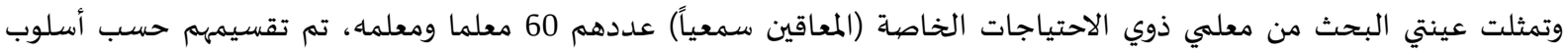

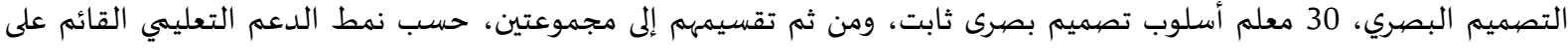

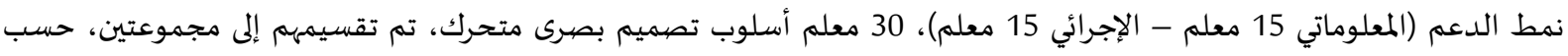

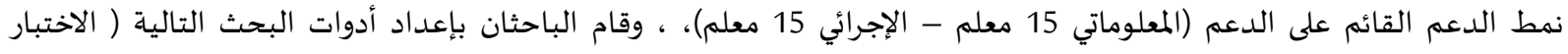

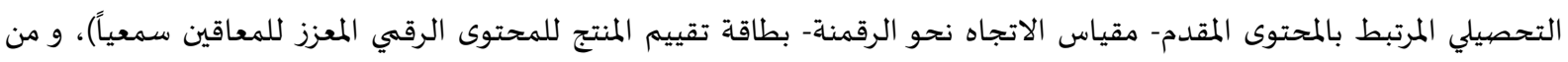

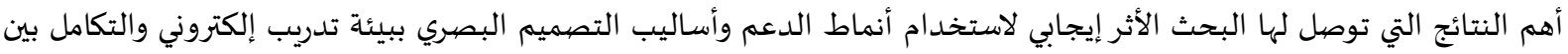

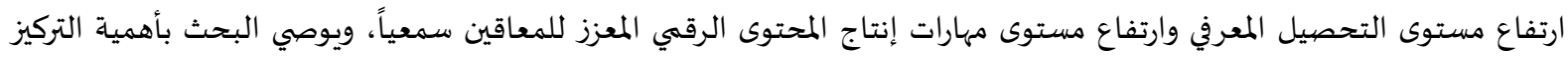

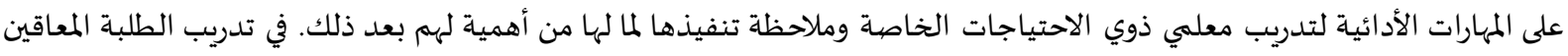

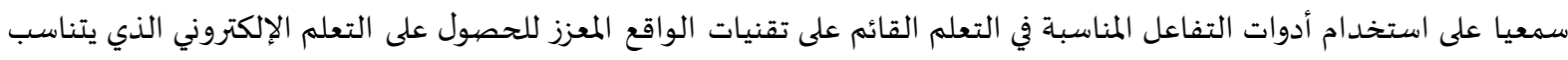

وخصائص تعلمهم.

الكلمات المفتاحية: أنماط الدعم الإلكتروني، التصميم البصري، المحتوى الرقمي المعزز، الاتجاه نحو الرقمنة، الطلاب المعاقين سمعياً.

المقدمة:

ان التطور التكنولوجي المستمروالمتزايد الذي نعيشها في العصر الحالي جعل المؤسسات التعليمية والتربوية في

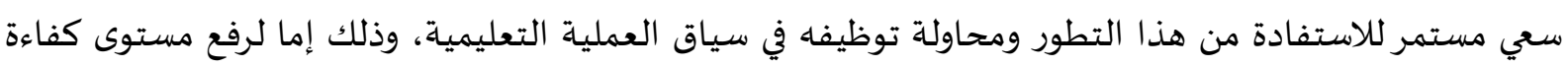
عملية التعلم بشكل عام واستغلال إمكانات وقدرات التلاميذ أو لحل المشكلات التي قد تعترض مستهاف مسار عملية التعلم

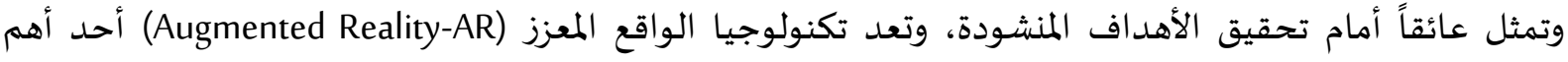

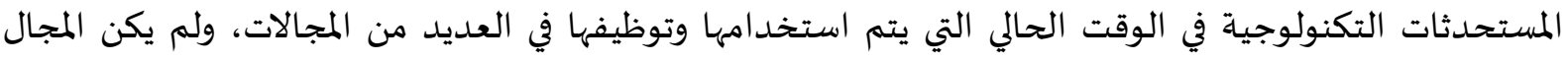

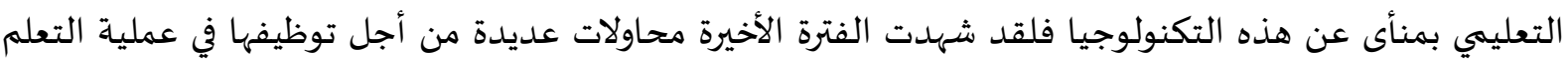

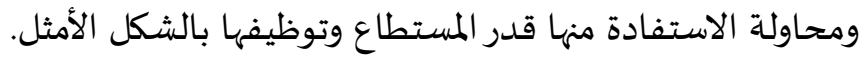

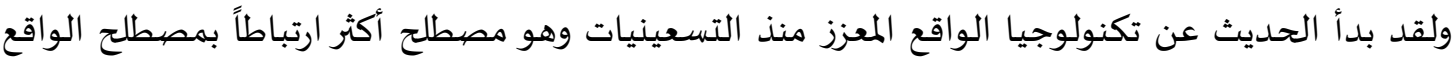

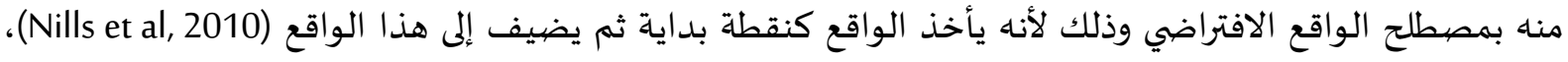

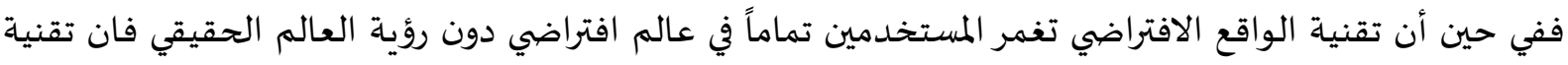
الواقع المعزز تزيد من إدراك المستخدم للعالم الحقيقي وتقوي من شعوره بالواقع عن طريق إضافة أشياء افتراضية المعافية

للعالم الحقيقي في الوقت الحقيقي (Julie \& Borko, 2011).

وتهدف تكنولوجيا الواقع المعزز إلى إنشاء نظام لا يمكن فيه إدراك الفرق بين العالم الحقيقي وما أضيف

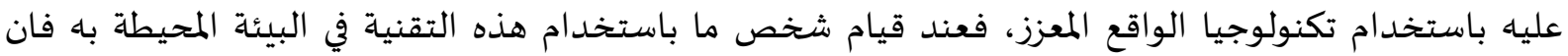

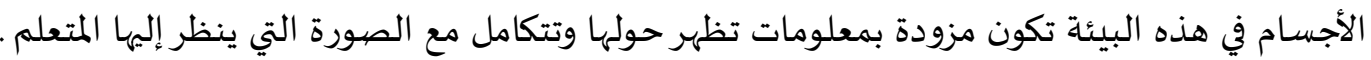

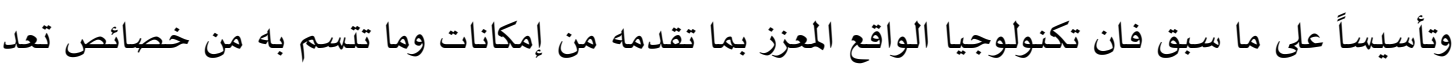

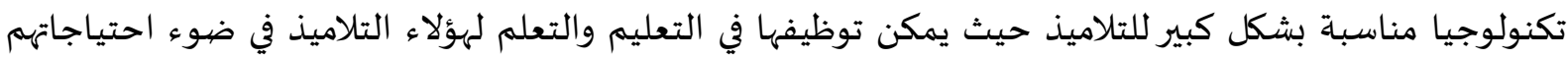
وخصائصهه، خاصة التلاميذ من ذوي الاحتياجات الخاصة (ريهام الغول، 2016 ) 
نبعت مشكلة البحث الحالي من خلال وجود قصور في الجوانب المعرفية والأدائية المرتبطة بمهارات إنتاج

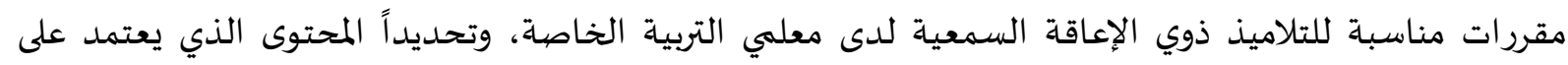

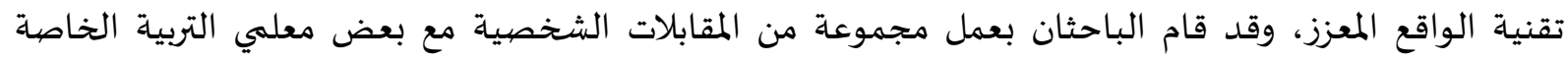

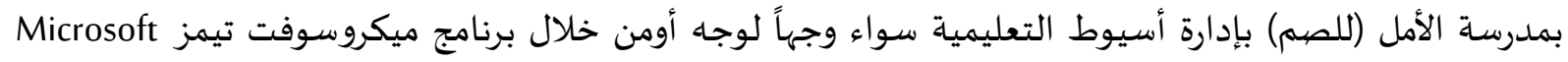

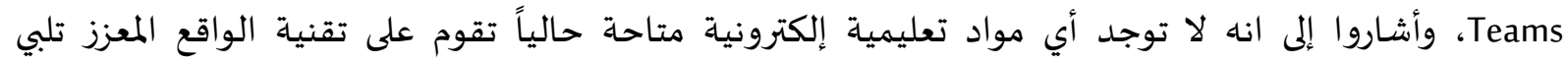

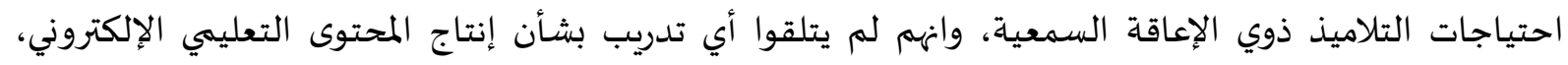

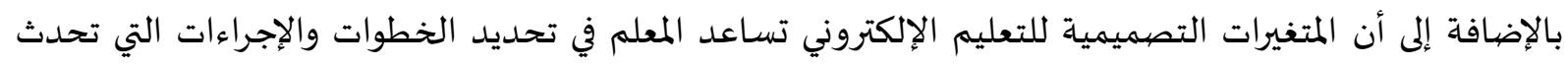

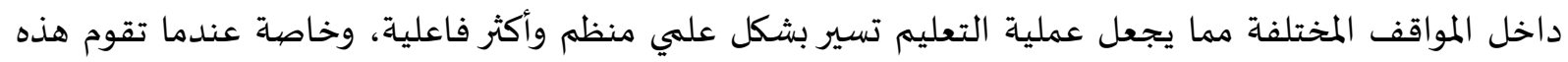

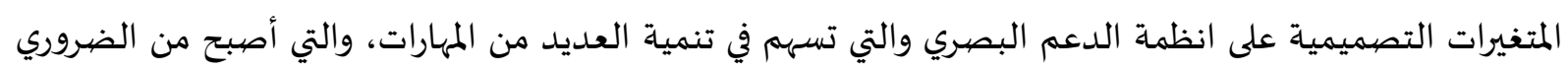

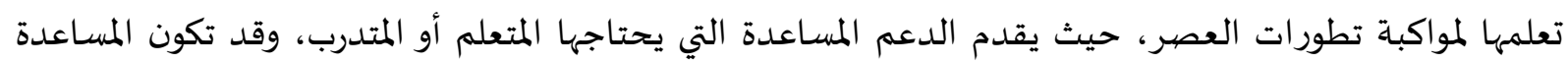

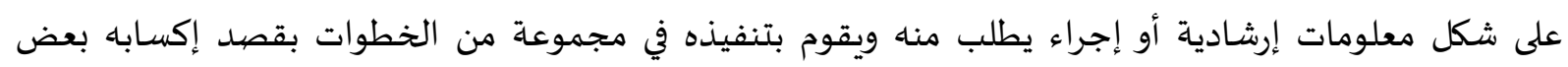

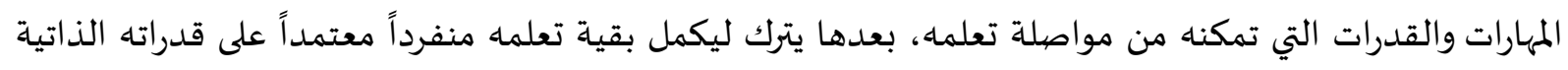

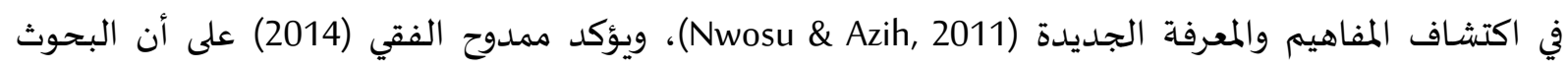

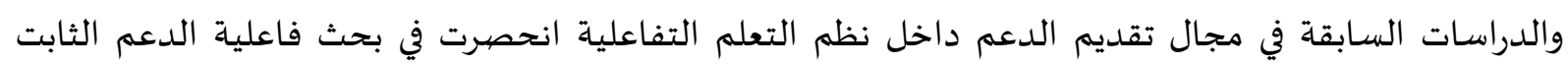

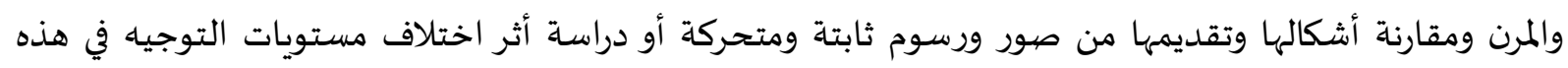

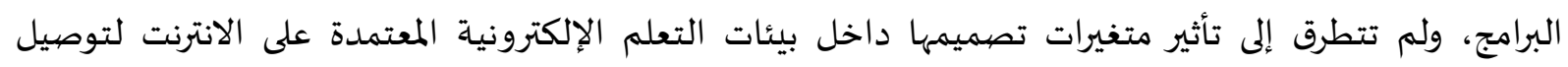

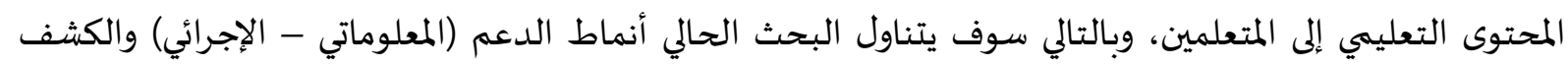

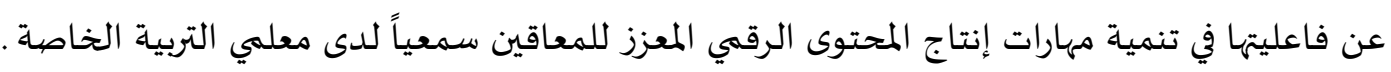

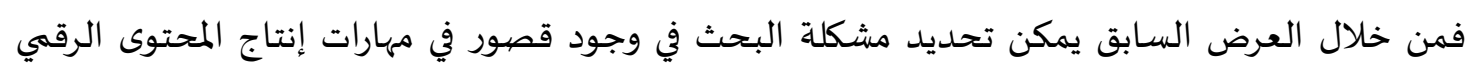

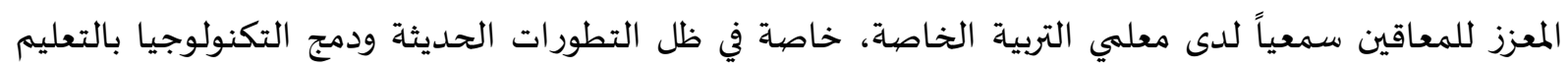

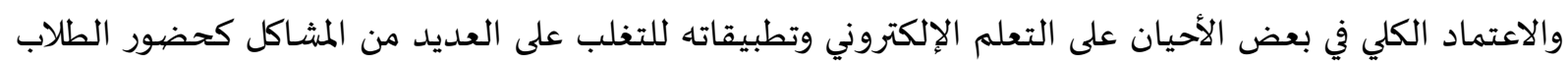

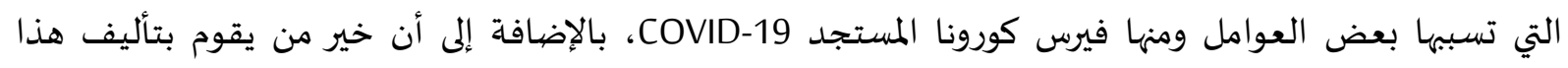

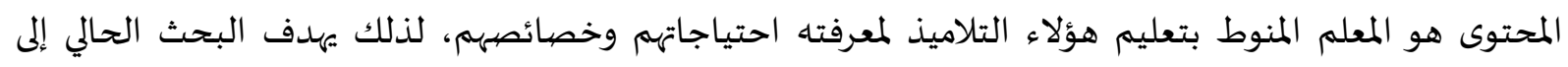

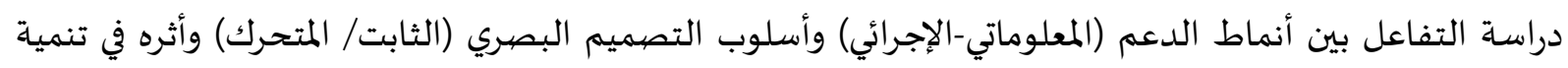

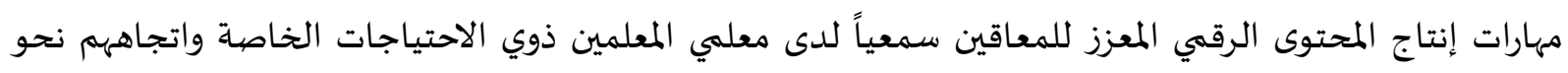
الرقمنة.

أسئلة البحث:

في ضوء ما تقدم يمكن معالجة البحث الحالي من خلال الإجابة عن السؤال الرئيس التالي:

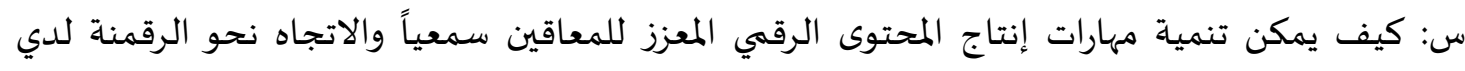

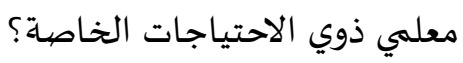

وبشكل أكثر تحديداً يحاول البحث الاجابة عن الأسئلة التالية:

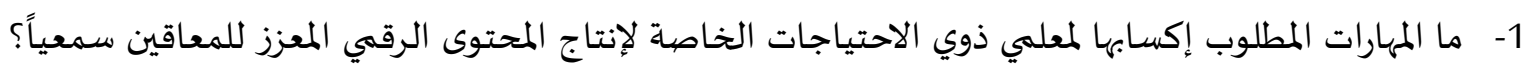

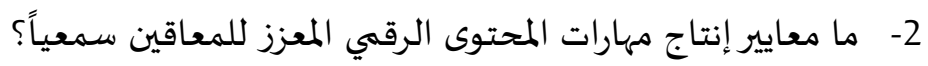


3- ما التصور المقترح للبرنامج التدريبي الإلكتروني لتنمية مهارات إنتاج المحتوى الرقهي المعزز للمعاقين سمعياً

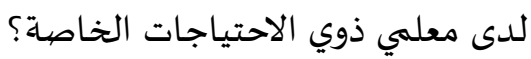

4- ما فاعلية استخدام أنماط الدعم (المعلوماتي-الإجرائي) وتفاعله مع أسلوب التصميم البصري (الثابت) في

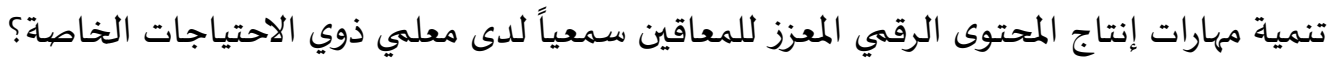

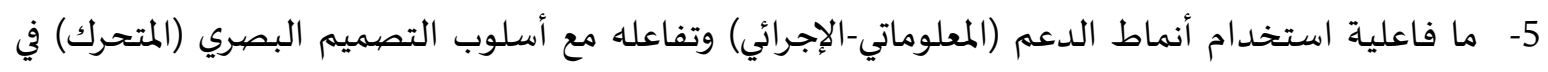

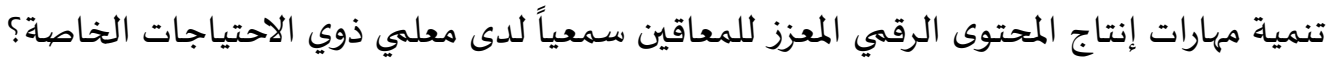

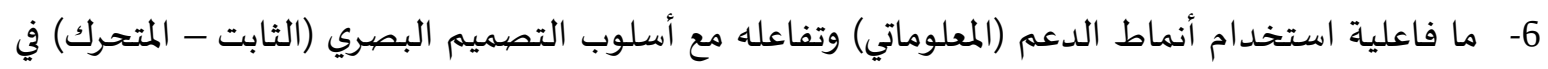

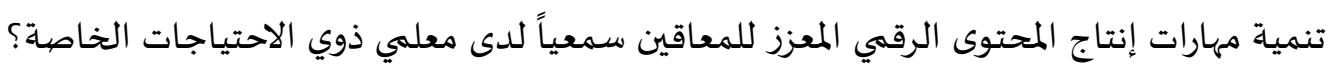

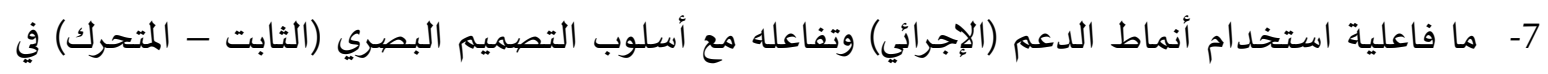

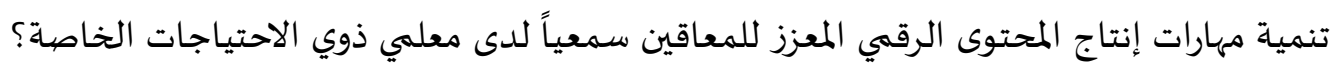

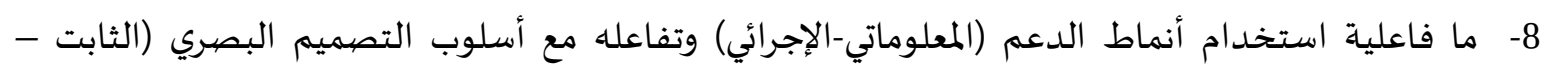

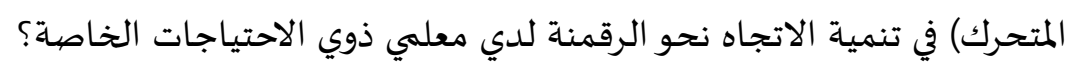

$$
\text { فرضيات البحث: }
$$

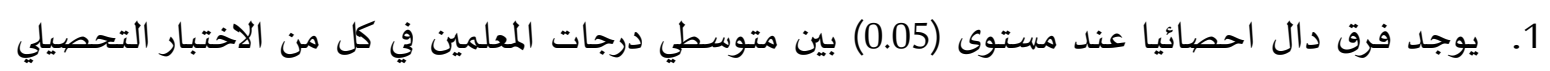

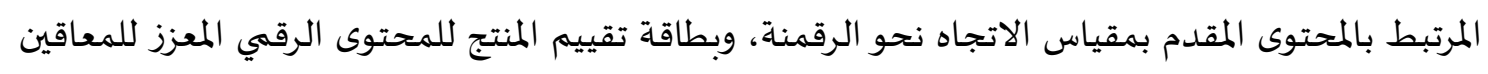

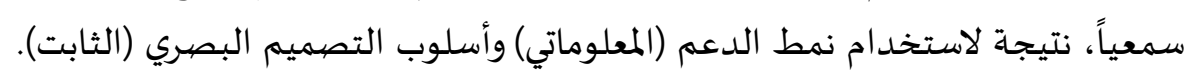

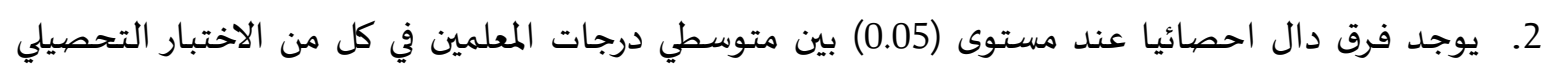

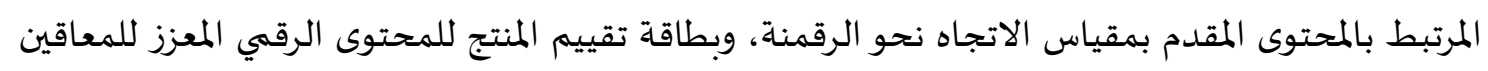

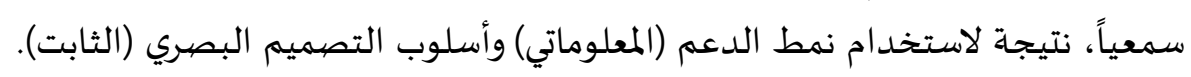

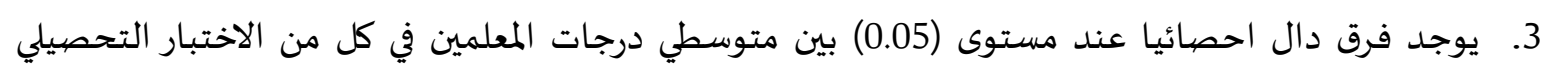

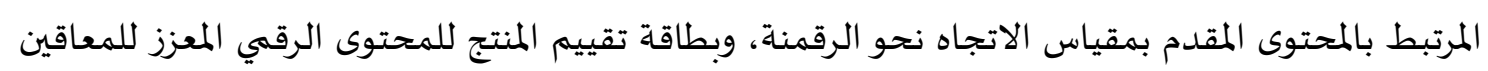

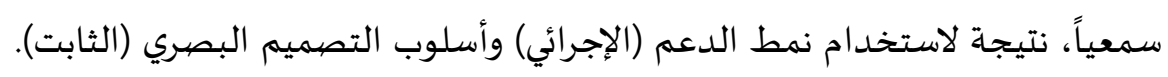

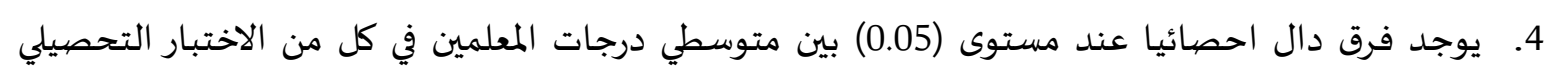

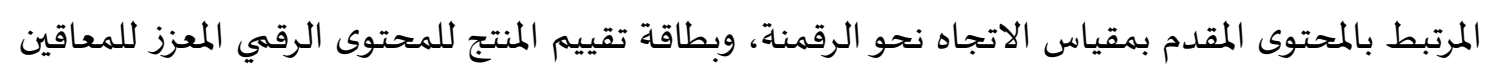

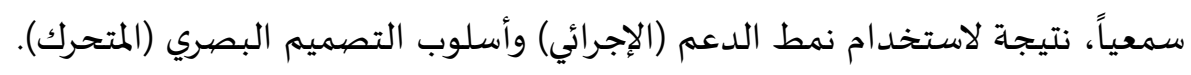

$$
\text { أهمية البحث: }
$$

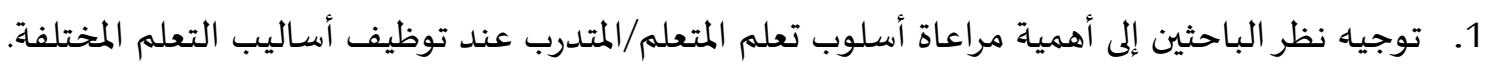

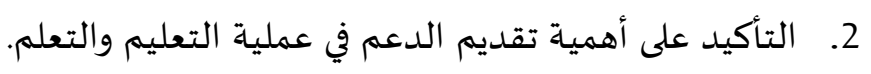

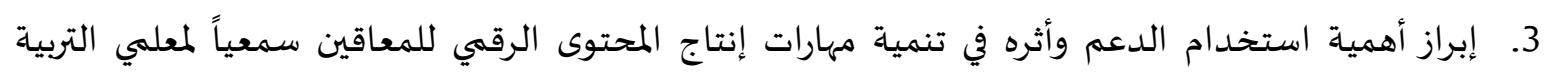
الخاصة. 4. تشجيع القائمين بالتدريس على استخدام الواقع المعزز في تعليم ذوي الاحتياجات الخاصة. 
ب- الأهمية التطبيقية للبحث:

1. تحديد النمط المناسب عند تقديم الدعم بما يفيد المصهمين التعليميين عند تصميم أشكال الدعم في

$$
\text { بيئات التعلم الإلكترونية. }
$$

2. تقديم نموذج قائم على استخدام أنماط الدعم (المعلوماتي-الإجرائي) وتفاعلهما مع أسلوب التصيميم البصري

$$
\text { المعلوماتي (الثابت/المتحرك). }
$$

حدود البحث:

اقتصر البحث الحالي على الحدود التالية:

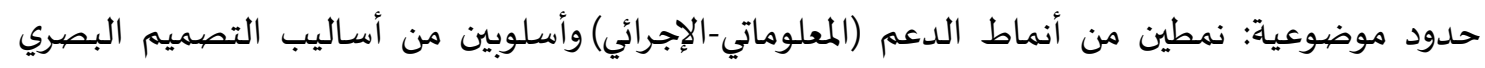

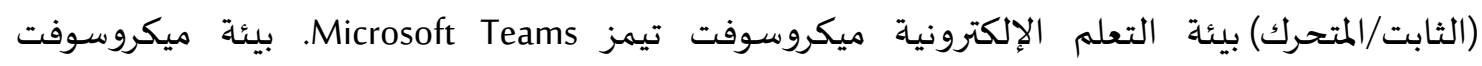

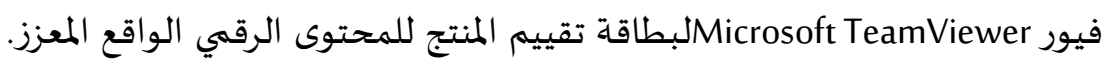

حدود بشرية: معلمي ذوي الاحتياجات الخاصة (المعاقين سمعياً).

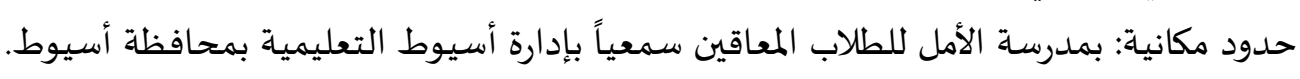

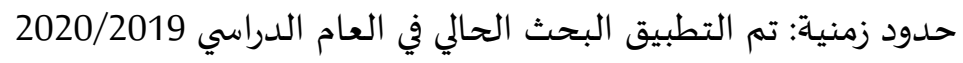

هيكلة البحث:

نظراً لان البحث الحالي يهدف إلى الكشف عن التفاعل بين أنماط الدعم (المعلوماتي-الإجرائي) وأسلوب

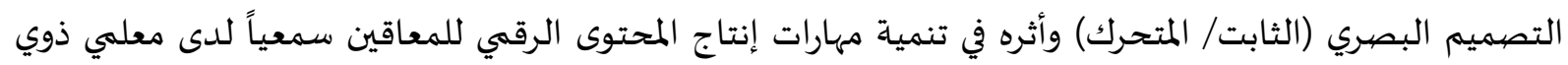

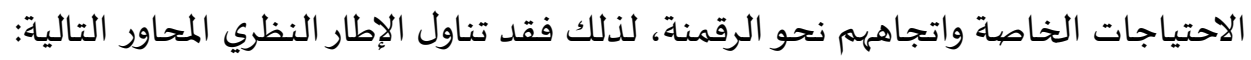

$$
\begin{aligned}
& \text { المحور الاول: أسلوب التصميم البصري (الثابت/ المتحرك) }
\end{aligned}
$$

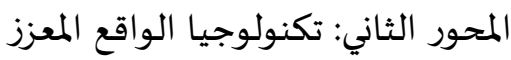

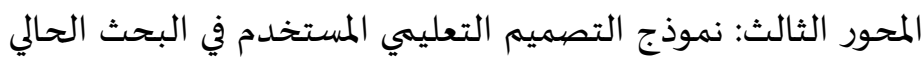

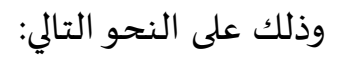

المحور الاول: أسـاليب التصهيم البصري(الثابت/ المتحرك):

أولاً: ماهية أسلوب التصميم البصري المعلوماتي:

يتعلم المتعلمون ويتذكرون ما تعلموه بشكل أكثر كفاءة وفعالية من خلال استخدام النصوص والمرئئيات أكثر من النص بمفرده، ويعد أسلوب التصميم البصري المعلوماتي طريقة لتقديم المعلومات المعقدة، والمكثفة

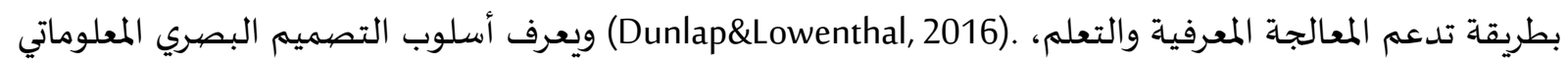

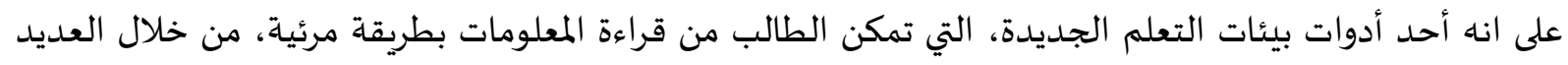

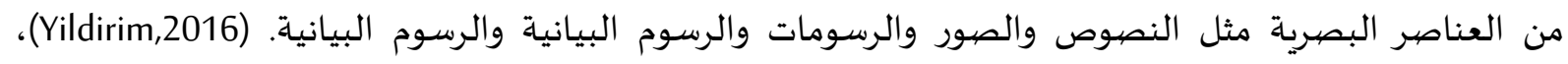

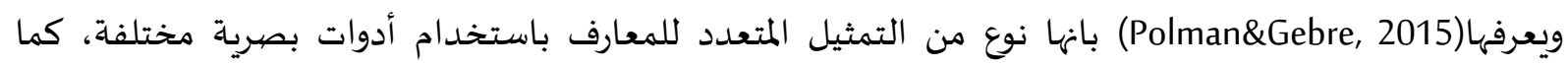

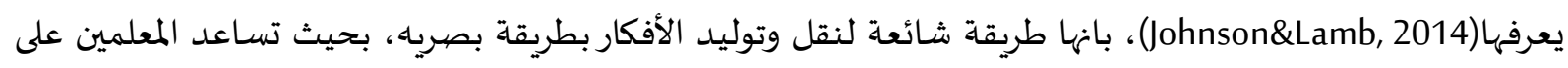

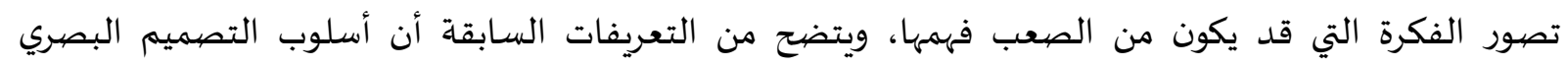


المعلوماتي (1) أداة لنقل وتوليد المعارف في صورة مرئية (2) يحقق ترسيخ وفهم المعارف والأفكار والعلاقات.(3) أداه

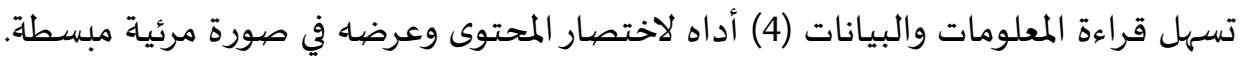

ثانياً: أهداف استخدام أسلوب التصيميم البصري المعلوماتي: يشير جونسون ولامب (Johnson \& Lamb, 2014)، أن الهدف من استخدام أسلوب التصميم البصري المعلوماتي في علميتي التعليم والتعلم يتمثل في الآتي: (1) عرض الأفكار والمعلومات بطريقة منظمة وجذابة (2) إظهار العلاقات المعقدة وتيسير فهمها واستنتاجها بطريقة مرئية (3) سهولة المقارنة بين المعلومات وسهولة تحليلها (4) جعل المعلومات ذات المعات معنى، وذلك لانها تدعم بالرسوم والصور (5) استخدام أسلوب التصميم البصري المعلوماتي في نقل الحدث والتمدئ التعبير عنده بطريقة مثيرة بالصيور، أو في شكل قصاة، بدلاً من استخدام الكلمات.

ثالثا: أهمية استخدام أسلوب التصميم البصري المعلوماتي في عمليتي التعليم والتعلم : اتفق كل من، (Dunlap\& Lowenthal,2016) على أن استخدام أسلوب التصميم البصري عملئيم المعلوماتي في عمليتي التعليم والتعلم يضفي العديد من المميزات منها: 1. التعلم من خلال النصوص المرئية يجعل التعلم أكثر كفاءة وفعالية وأبقى أثراً.

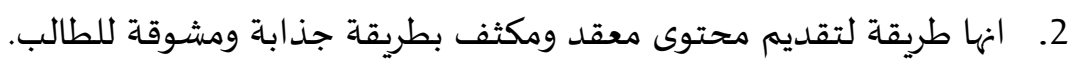

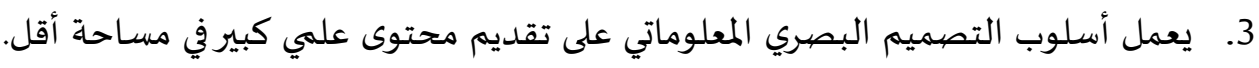

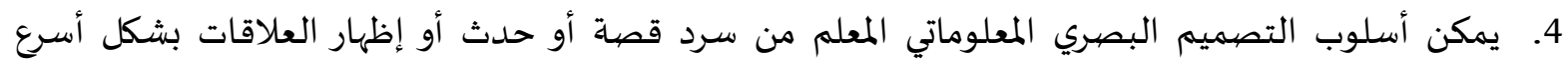
وأسهل. 5. يمكن من تحسين فهم واستيعاب المعرفة لقدرتها على تحسين قدرة النظام المرئي البشري على رؤية الأنماط والاتجاهات. 6. يسـاعد أسلوب التصميم البصري المعلوماتي على جعل المتعلم نشطاً وفعالاً، حينما يطلب منه إعداد أسلوب

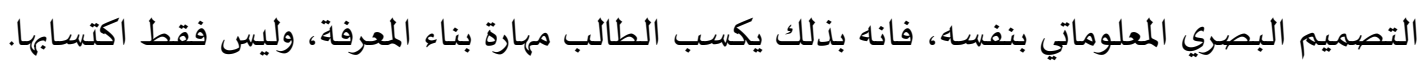
7. يساعد أسلوب التصميم البصري المعلوماتي على تقديم محتوى تعليمي واضح ودقيق. 8. يعمل أسلوب التصميم البصري المعلوماتي على تحسين قدرات المعلمين وأثراء جوانب التفكير الإبداعي لديهم. 9. يساعد أسلوب التصميم البصري المعلوماتي على بناء المعرفة.

\section{رابعاً: أنماط أسلوب التصهميم البصري المعلوماتي:} يميز كل من تسانكوف وداميانوف (Tsankov \& Damyanov,2018)، بين ثلاثة انواع رئيسة من أسلوب المعائ التصيميم البصري المعلوماتي من حيث الشكل: 1. أسلوب التصميم البصري المعلوماتي الثابت: أبسط وأشمل نوع من أنماط التصميم البهمئ البصري، ويتكون من صورة ثابتة دون عناصر متحركة بها، وقد يتم تصميمه رأسياً، أو أفقياً، أو عمودياً أو دائرياً.

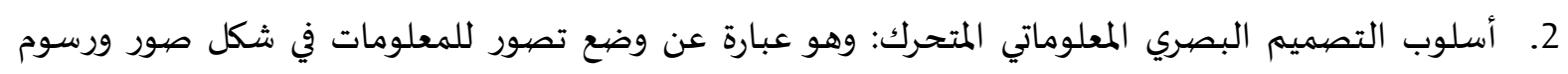
متحركة. 3. أسلوب التصميم البصري المعلوماتي التفاعلي: وهو عبارة عن تكوين ديناميكي لمجموعة من العناصر المتحركة

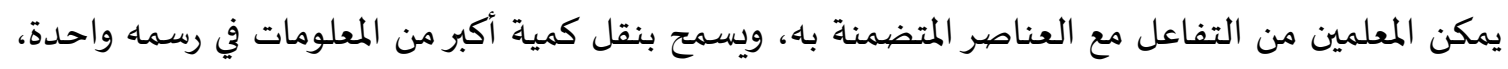


ومن الدراسات التي تناولت الأنماط المختلفة من أسلوب التصميم البصري المعلوماتي التعليمي دراسة محمود

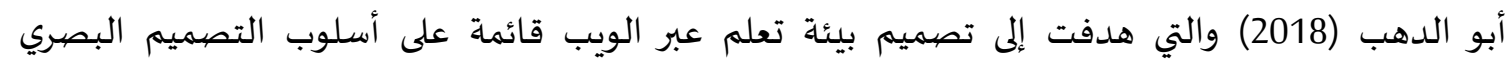

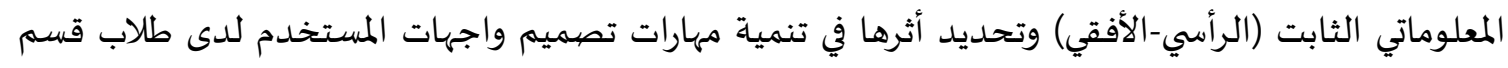

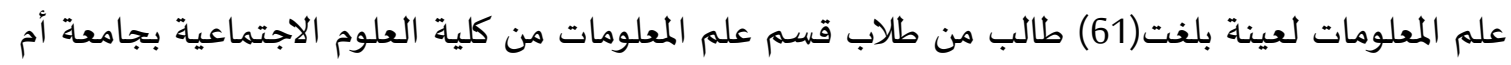

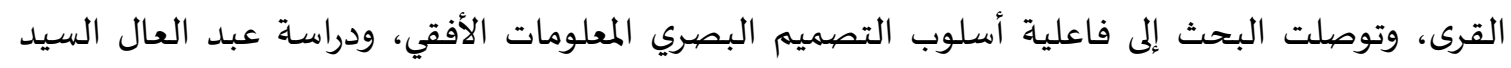

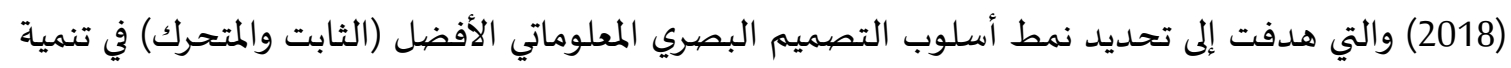

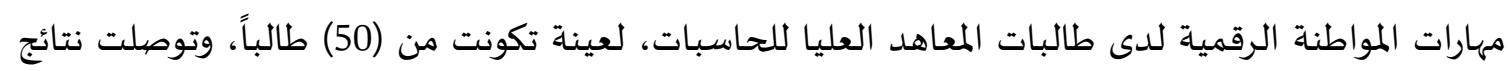
البحث إلى تفوق نمط أسلوب التصميم البصري المعلوماتي المتحرك. من خلال العرض السابق يتضح أن هناك عدد من الدراسات التي تناولت بعض الأنماط المختلفة (الثابت

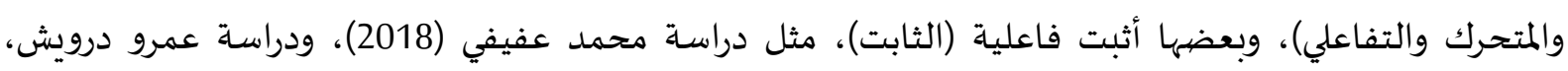

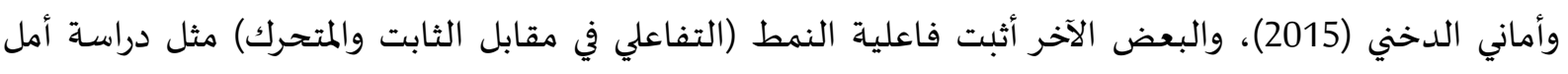

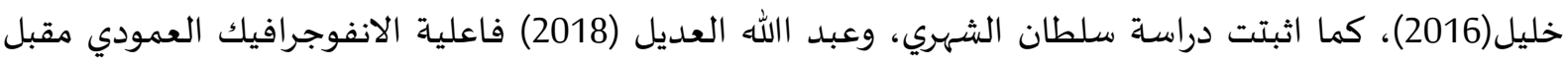
الدائري، وأثبتت دراسة محمود أبو الدهب(2018) فما أبتَت دراسلية أسلوب التصميم البصري المعلوماتي الأفقي مقابل الرأسي.

\section{أما أنماط أسلوب التصميم البصري المعلوماتي من حيث الإعداد، فهي:}

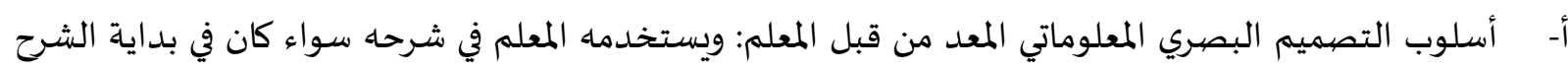

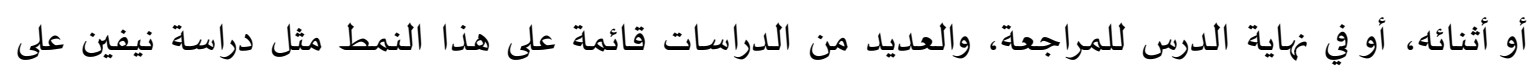

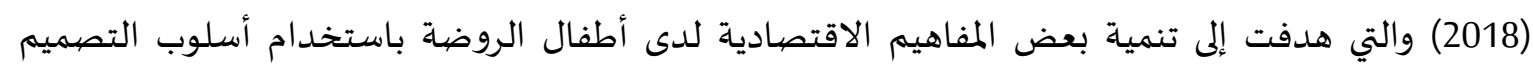

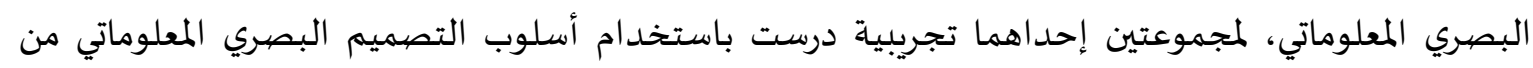

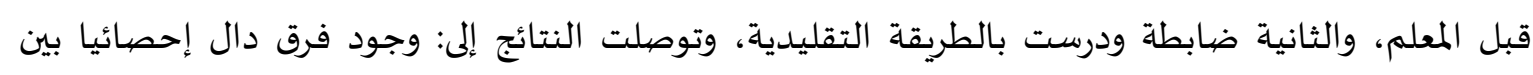

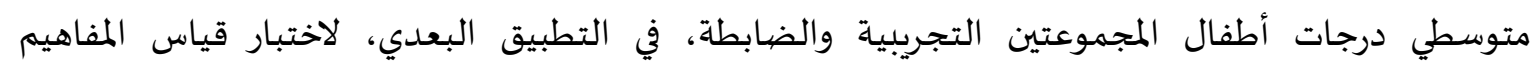

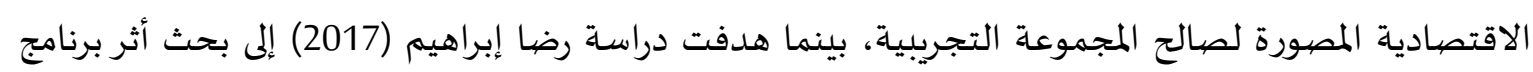

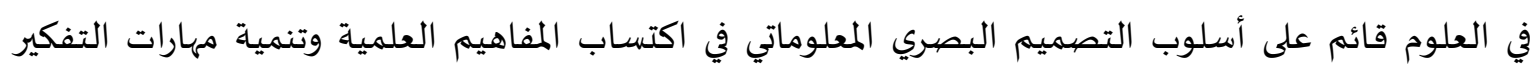

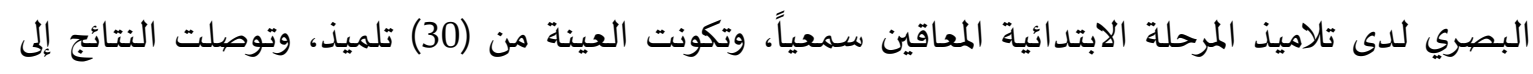

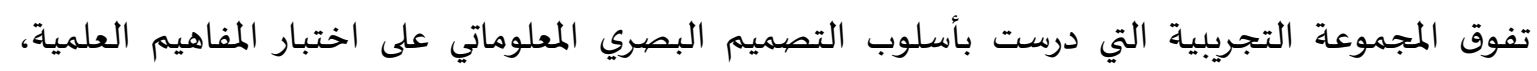

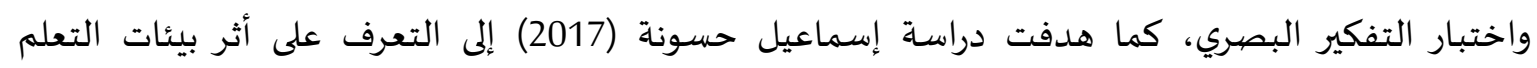

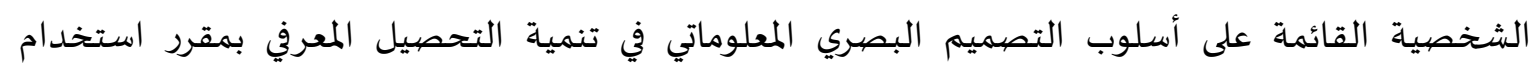

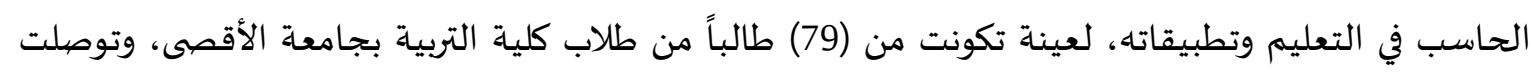

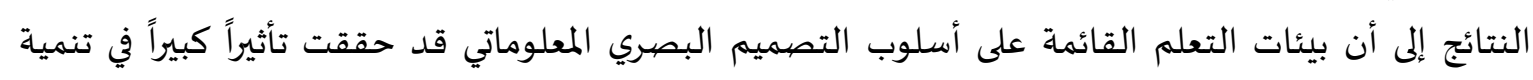

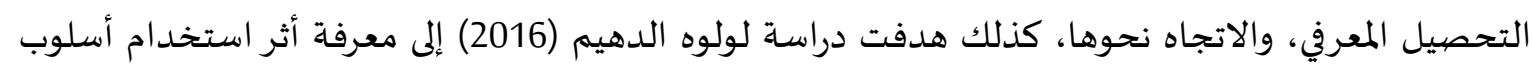

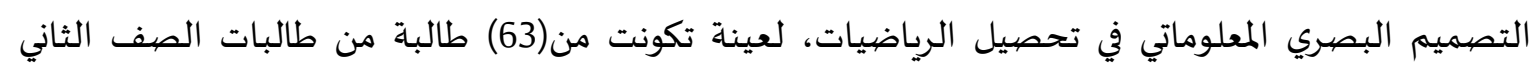

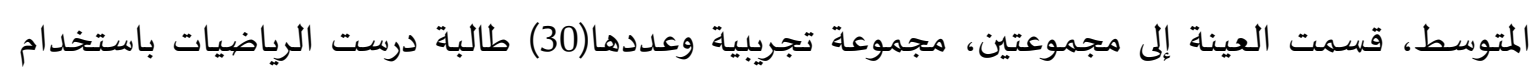

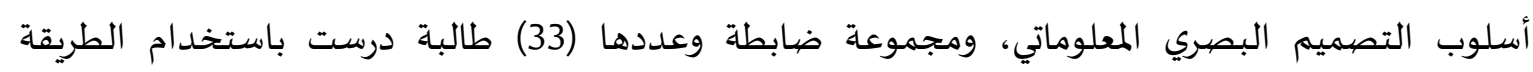

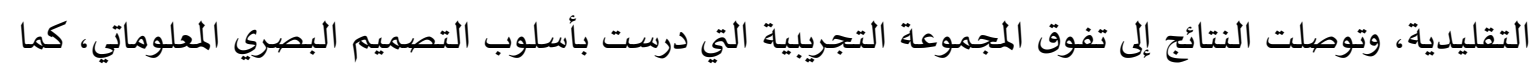

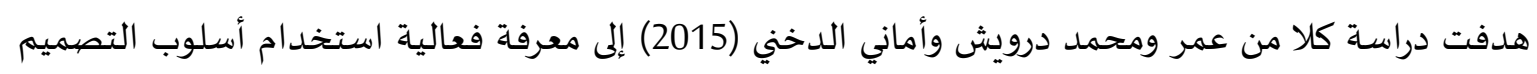


البصري المعلوماتي على الأداء المهارى والتحصيل المعرفي لمسابقة الوثب الطويل، لعينة تكونت من (70) طالباً من

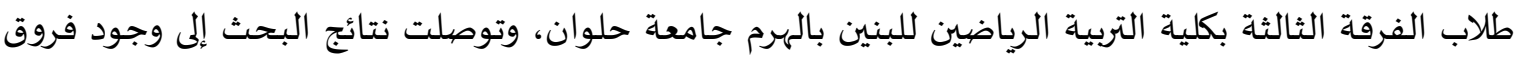

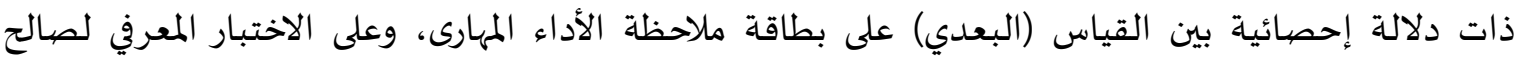

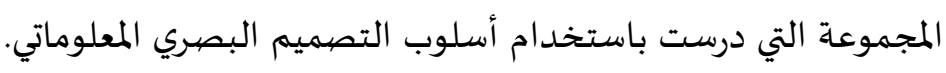

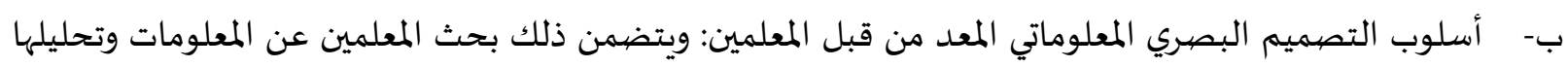

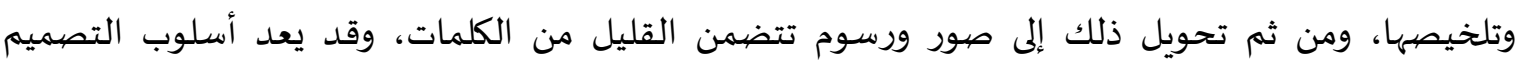

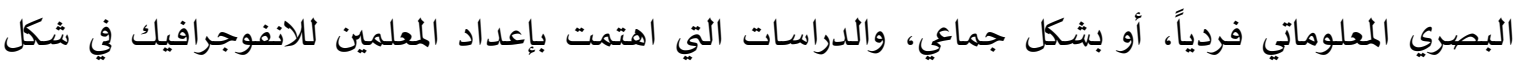

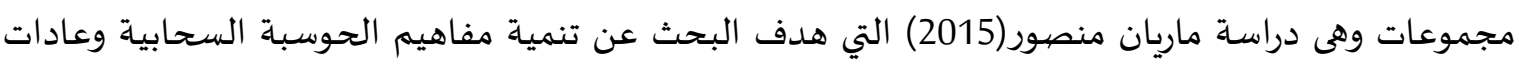

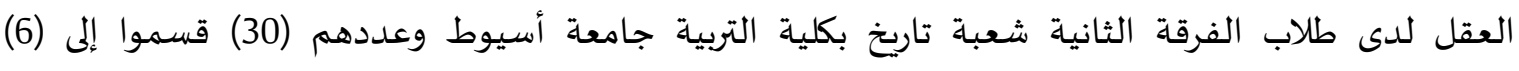

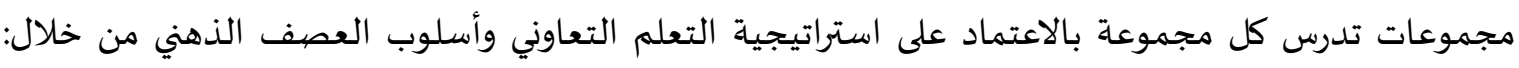

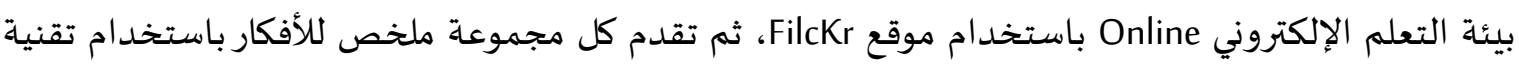

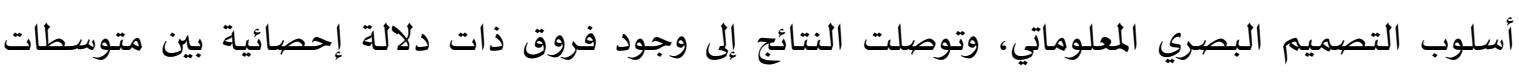

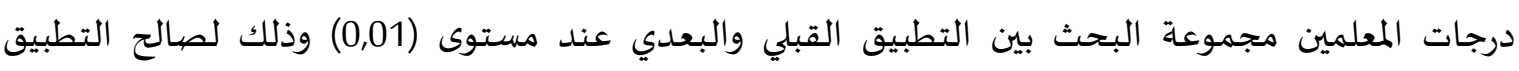

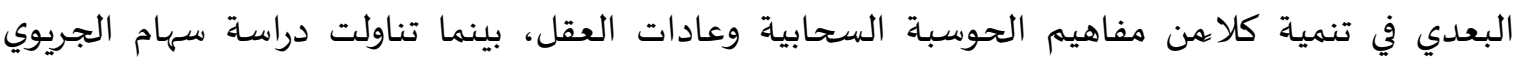
(2014) إعداد المعلمين للانفوجرافيك بشكل فردي حيث هدفت دراستها إلى إلى معرفة فعالية استخدام برنامج

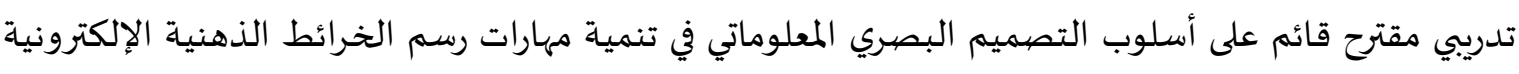

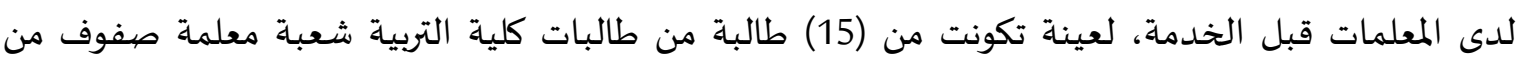

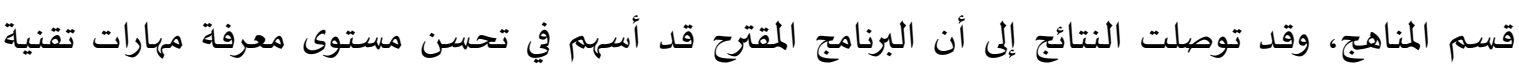
تصاميم أسلوب التصميم البصري المعلوماتي في تصميم خرائط ذهنية الإلكترونية للدروس التصني التعليمية.

\section{Augmented Reality Technology: المحور الثاني: تكنولوجيا الواقع المعزز} تعد تكنولوجيا الواقع المعزز وليدة القرن العشرين فأول ظهور فعلي لتقنية الواقع المعزز كان في أواخر عام

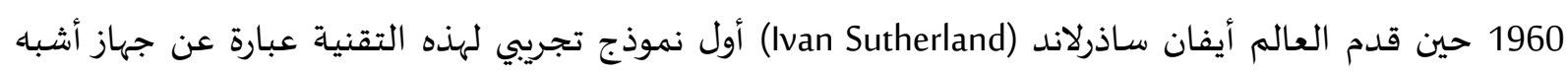

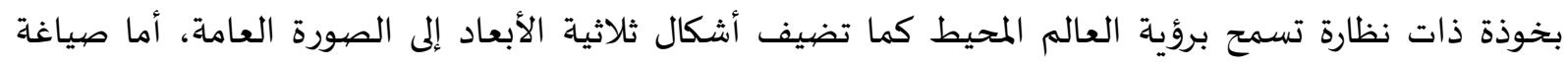

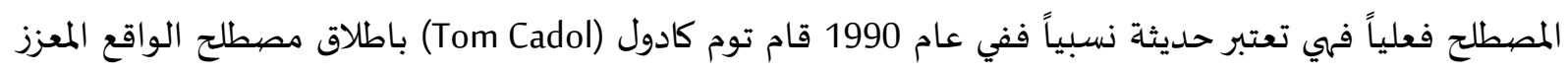

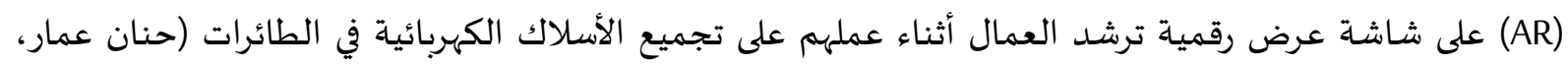

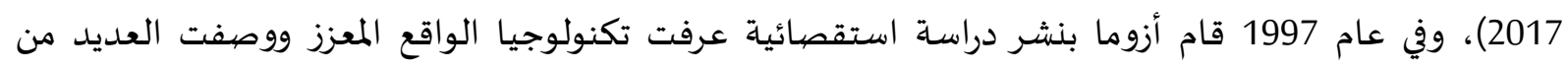
المشاكل التي تواجه تلك التكنولوجيا، ومنذ ذلك الحين أحرز هذا المجال نمواً وتقدماً ملحوظين (Azuma et al., )

مميزات توظيف تكنولوجيا الواقع المعزز في التعليم: تمديم

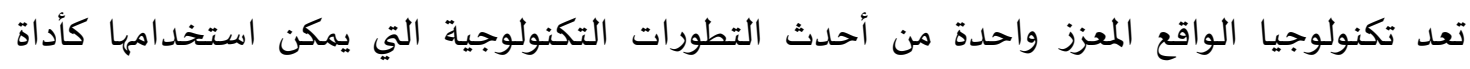

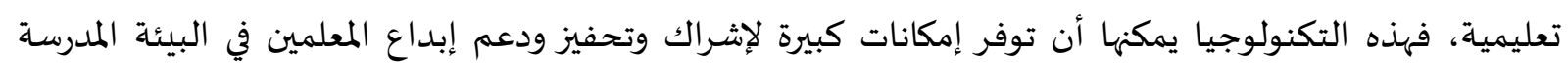

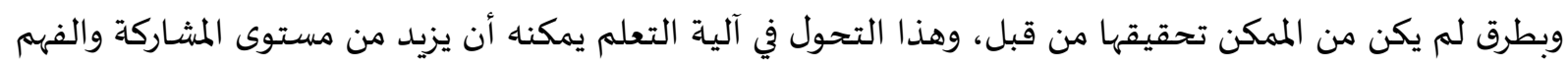
والتعلم وهي عناصر أساسية في جميع النظم التعليمية. 


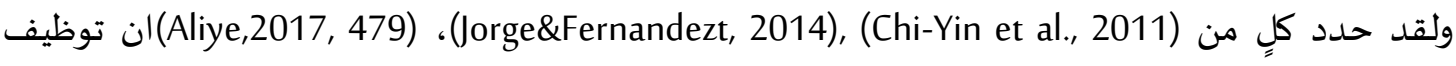

$$
\text { تكنولوجيا الواقع المعزز في التعليم له عديد من من المميزات، منها: }
$$

توفر هذه التكنولوجيا سياق غني للتعلم اكتساب المعارف وتطوير الأداء، وهو الأمر الذي أكدتاه دراسة مها

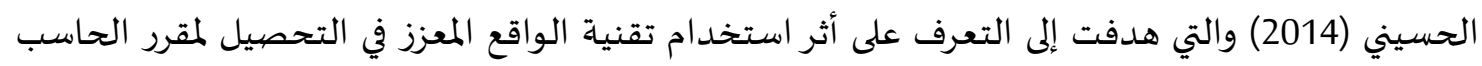

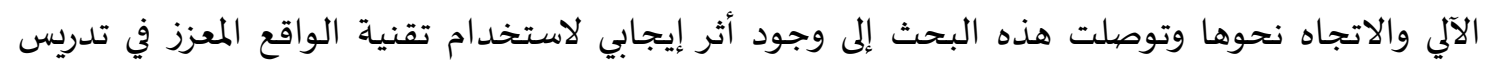

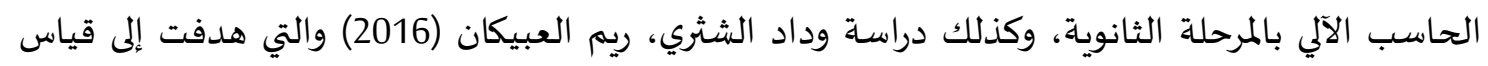

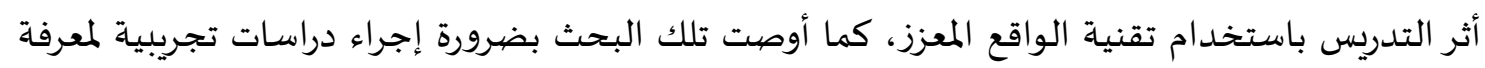
أثر التدريس باستخدام الواقع المعزز على التحصيل الدراسي في مقررات أخرى ولمراحل دراسية مختلفة.

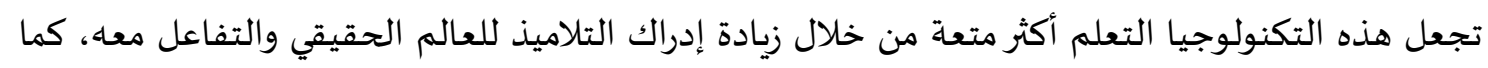
تسمح هذه التكنولوجيا للطلاب بالتفاعل الحر مع الأشياء الافتراضياة.

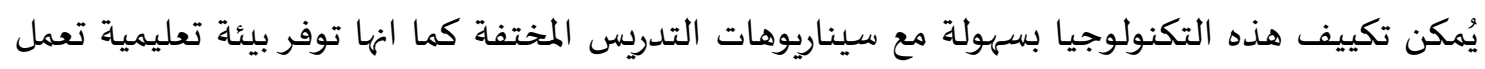
على إشراك جميع الحواس لدى التلميذ. تدعم هذه التكنولوجيا عملية بناء ومعالجة المعلومات لدي التلميذ، كما انها توفر فرصاً للتعلم الأمثل ومراعاة أنماط التعلم المتعدد حيث يتمكن كل طالب من اكتشاف طريقه الخماص. تساعد هذه التكنولوجيا في تدريس المواد التي لا يمكن للتلاميذ ممارستها بشكل مباشر وحقيقي في الواقع التعاست كعلوم الفضياء. في هذه التكنولوجيا لا توجد عواقب حقيقية إذا حدث أي خطأ أثناء التدريب على المهارات، كما يمكنها

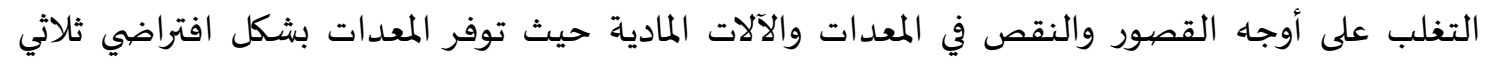

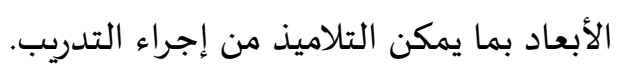
تعمل هذه التكنولوجيا على تعزيز التعاون بين التلاميذ والمعلمين وبين التلاميذ وانفسهم من خلال تطبل تطبيقات التهات الواقع المعزز التعاونية التي تعتمد في تصميمها على التشارك بين المتعلمين في أداء المهام التعليمية.

$$
\text { المحور الثالث: نموذج التصيميم التعليمي المستخدم في البحث الحالي : }
$$
تطلبت عملية تصميم وإنتاج المحتوى وتقديمه من خلال بيئة التعلم الحالية القائمة على منصية ميكروسوفت تيمز Microsoft Teams ضرورة الاطلاع على نماذج التصميم التعليمي المتعلقة بتصميم وتطوير بيئات

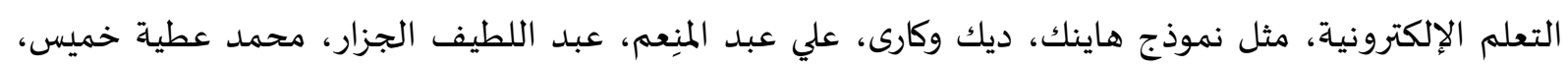

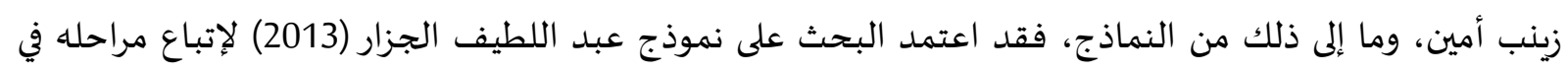

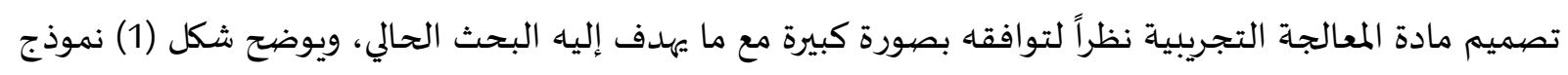
عبد اللطيف الجزار (2013) للتصميم التعليمي لمستحدثات التعلم الإلكترونية. 


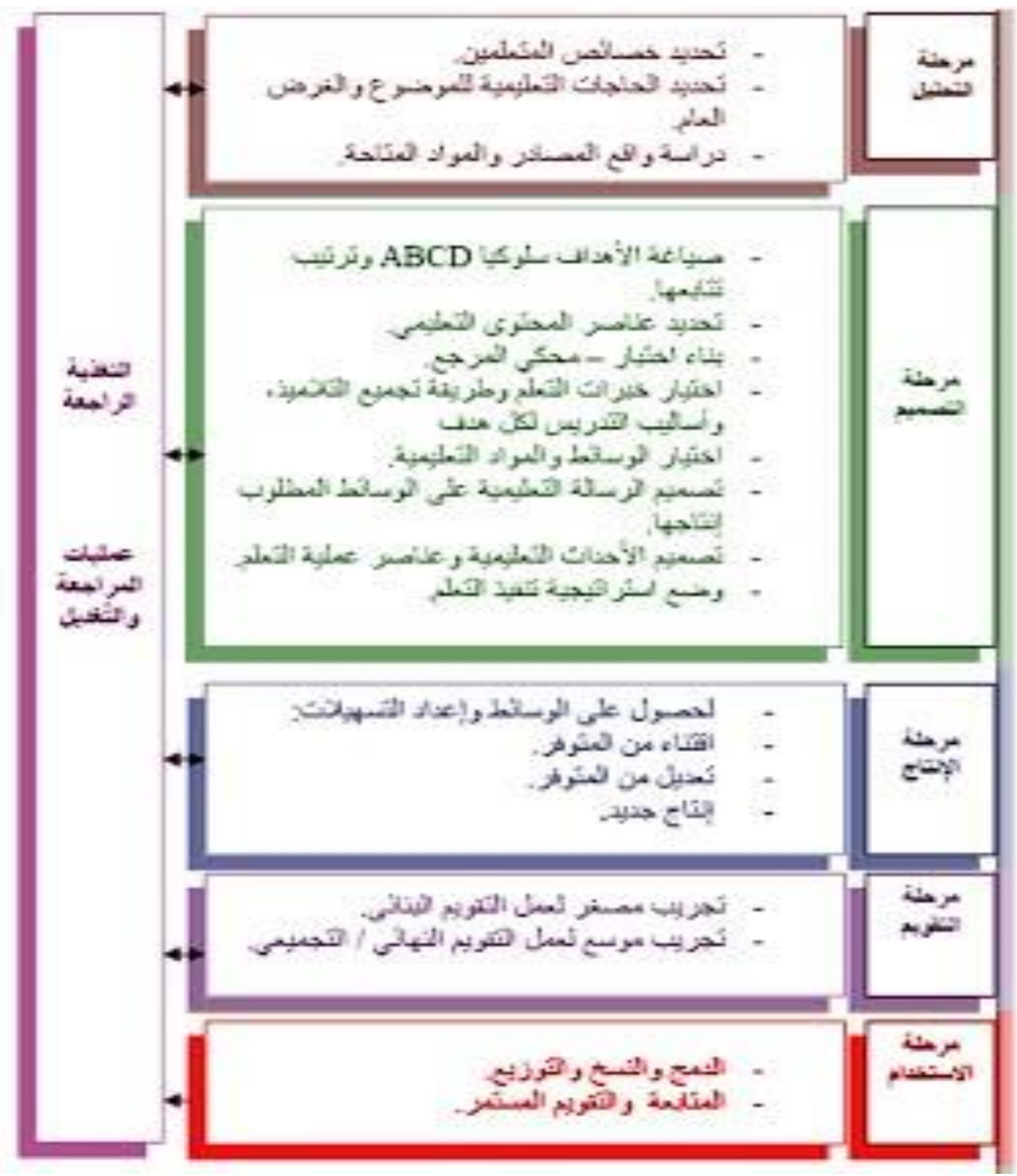

شكل (1) نموذج عبد اللطيف الجزار (2013)

للتصيميم التعليمي للتعلم الإلكتروني.

إجراءات البحث

نظراً لان البحث الحالي يهدف إلى الكشف عن أثر التفاعل بين أنماط الدعم (المعلوماتي/الإجرائي) وأسلوب

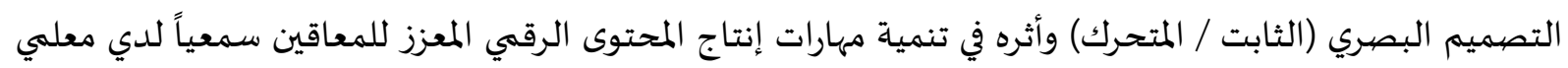

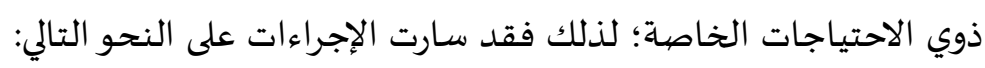

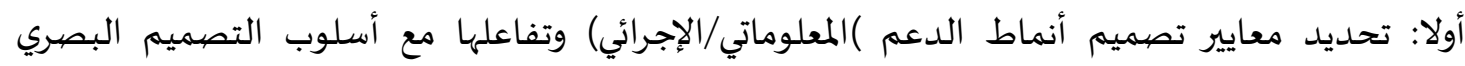

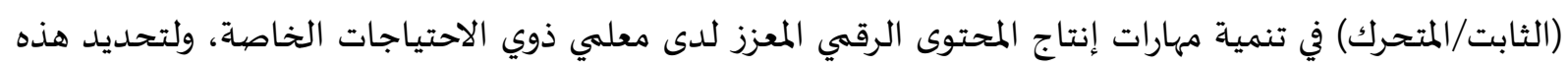

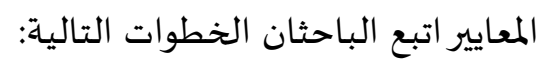


1- تحديد القائمة المبدئية لمعايير تصميم الدعم الإلكتروني التعليمي القائمة على الدعم البصري، كما وردت

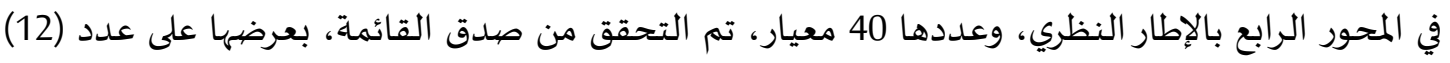

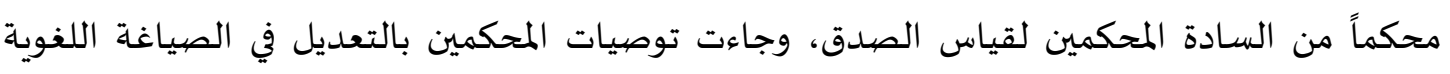

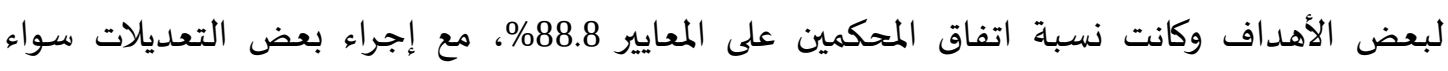

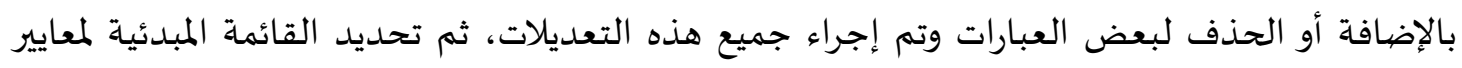

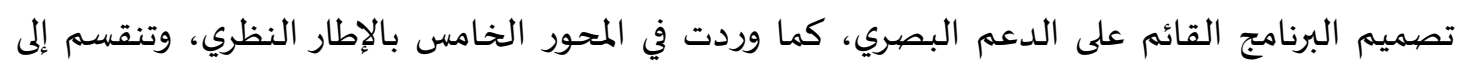

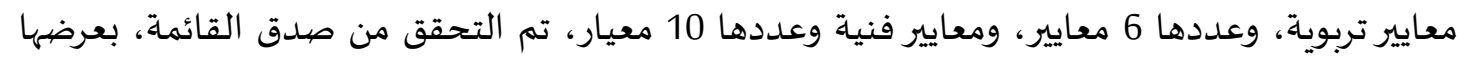

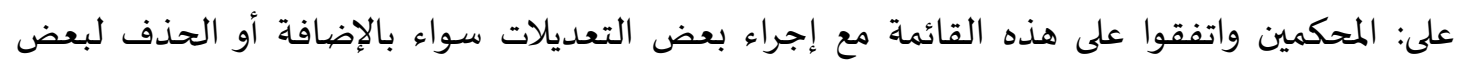
العبارات وتم إجراء جميع هذه التعديلات.

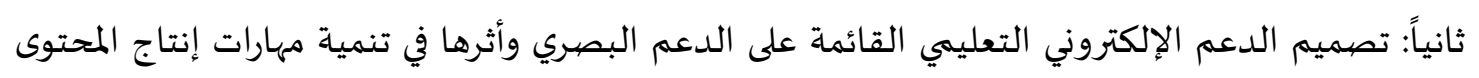

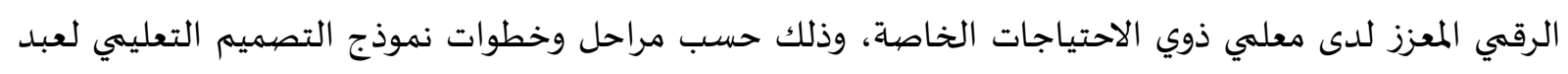
اللطيف الجزار (2013)، كما يلي:

أولا: مرحلة التحليل وتشمل على ما يلي:

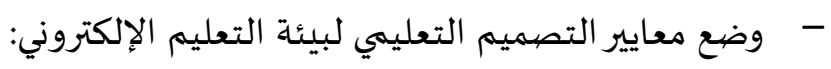
حيث تم اعتماد معايير التصميم التعليمي للدعامات التعليمية القائمة على الدعم البصري في بئئة البئة تعلم

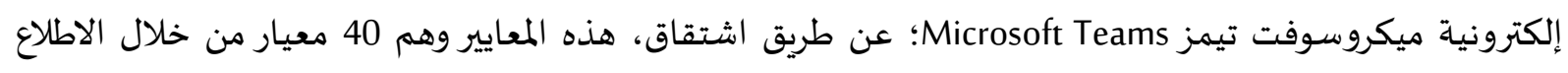

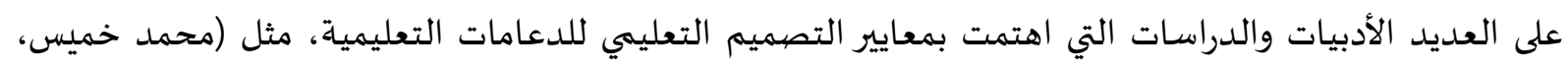

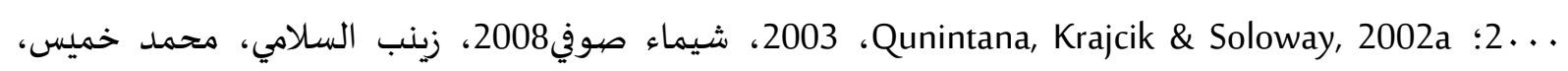

2009، طارق عبد السلام، 2010).

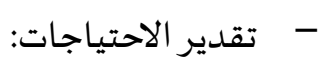

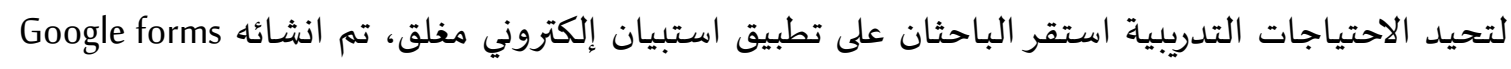

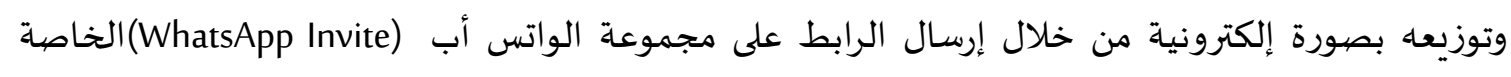

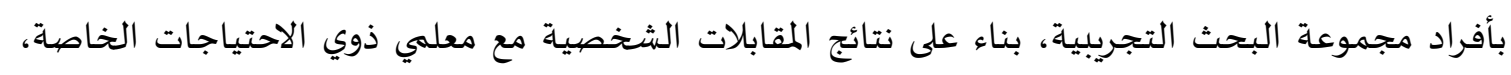

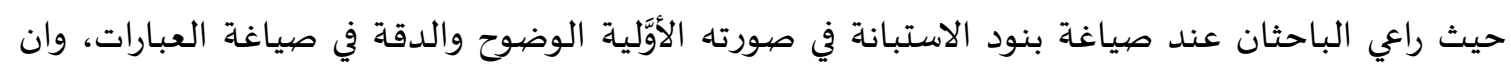

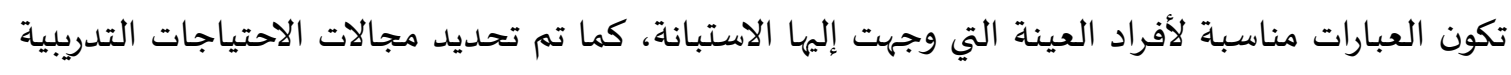

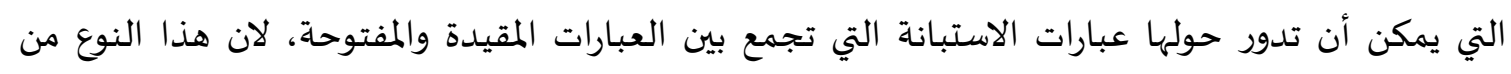

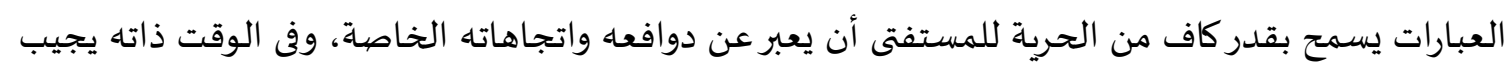

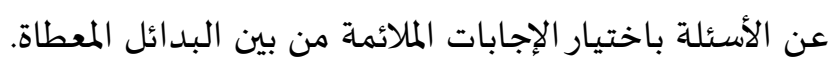

ثانياً: مرحلة التصيميم: Design: تصميم مكونات بيئة التعلم الإلكتروني:

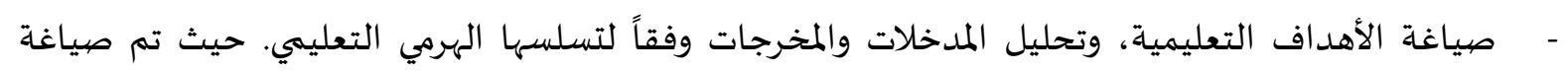

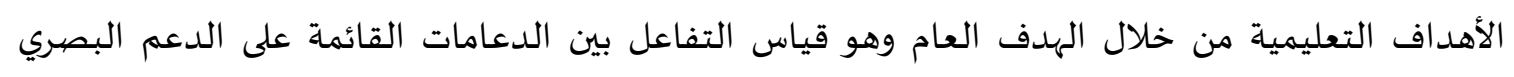

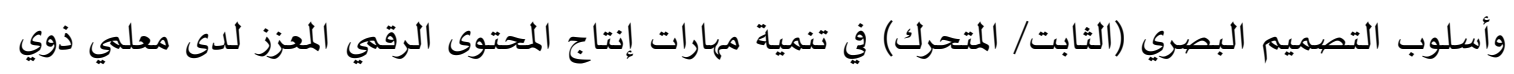




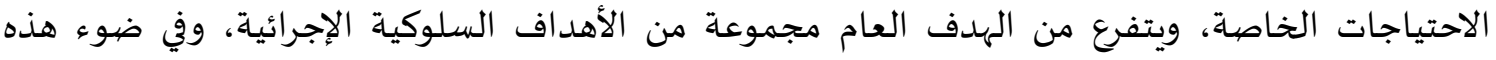

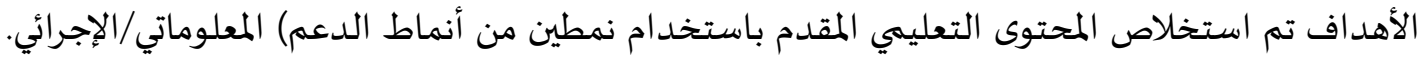

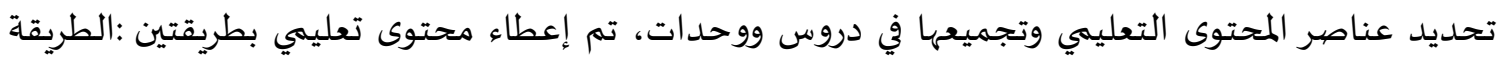

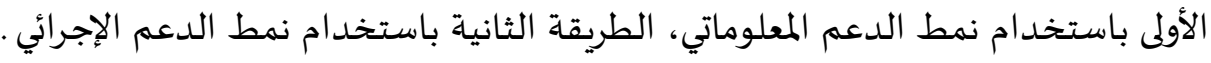

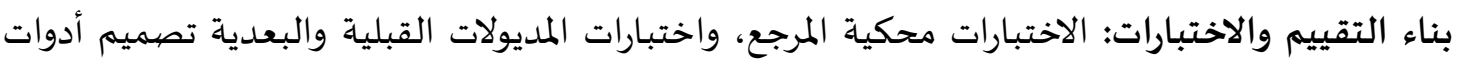

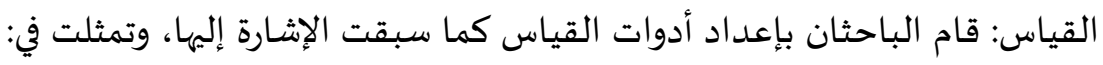

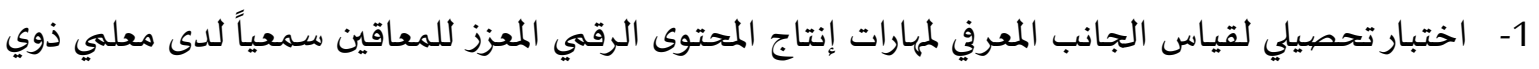

$$
\text { الاحتياجات الخاصة. }
$$

2- بطاقة ملاحظة الجانب الأدائي لمهارات إنتاج المحتوى الرقهي المعزز للمعاقين سمعياً لدى معلمي ذوي

$$
\text { الاحتياجات الخاصة. }
$$

3- بطاقة تقييم المنتج للمحتوى الرقهي المعزز للمعاقين سمعياً المنتج من قبل المعلمين عينة البحث.

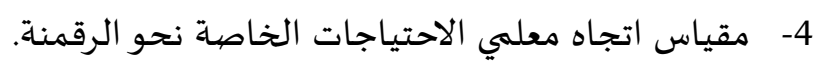

إملماً بان كل أدوات القياس تم تقدي الديمها إسات إلكترونيا من خلال بيئة التعلم الإلكترونية ميكروسوفت تيمز

Microsoft Teams، وسيتم شرح أدوات القياس بالتفصيل لاحقاً.

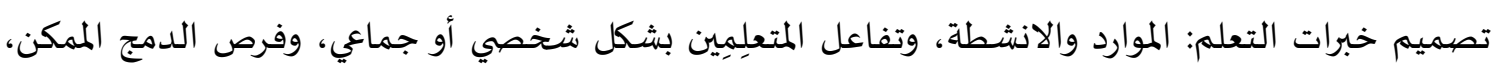

$$
\text { وروابط ويب، ودور المعلم لكل هدف. }
$$

- اختيار الموارد والانشطة: تم إرسال المحتوى إلى المجموعات الأربعة في شكل موديولات تعليمية حسب تقسيم

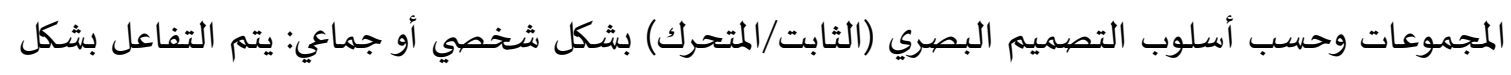

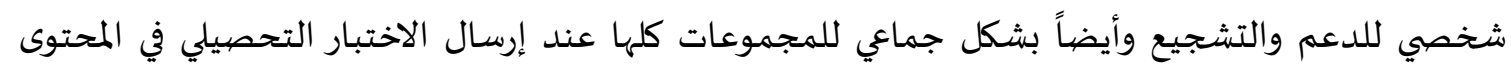
المقدم، أو التفاعل لكل مجموعة حسب هدف التفاعل حيث يرسل لكل مجموعة المحتوى بشكل الدعم الخاص بها.

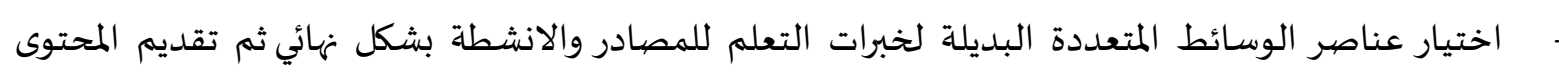

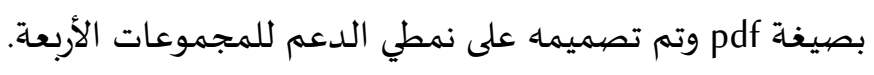
في ضوء خصائص المتعلمين وأهداف المحتوى التعليمي وتحديد الاستراتيجيات التعليمية المناسبة، أمكن صياغة السيناريو الذي يهدف إلى ترجمة المحتوى إلى إجراءات تفصيلية لتنظيم العناصر في بيئة التعلم الإلكترونية

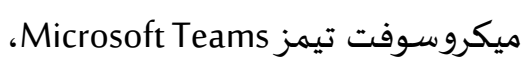
- إعداد السيناريوهات: السيناريو هو خريطة لخطة إجرائية تشتمل على خطوات تنفيذية لتصميم وإنتاج مصدر

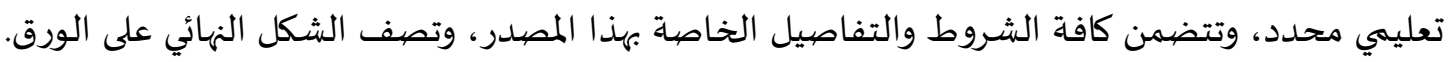

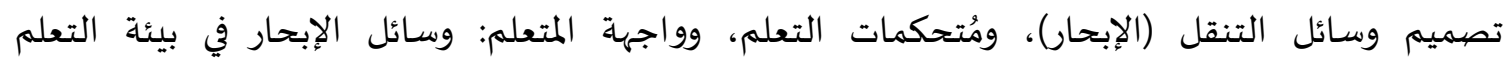
ميكروسوفت تيمز Microsoft Teams متنوعة وجاهزة بمجرد الضغط على أي أيقونة يتم الانتقال إلى شاشة

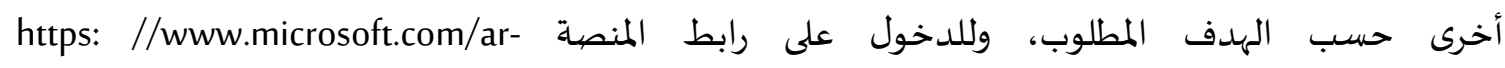
$. w w / m i c r o s o f t-t e a m s / \log$-in تصميم واجهات التفاعل: تتيح منصة إدارة التعلم ميكروسوفت تيمز MICROSOFT TEAMS أنماط التفاعل

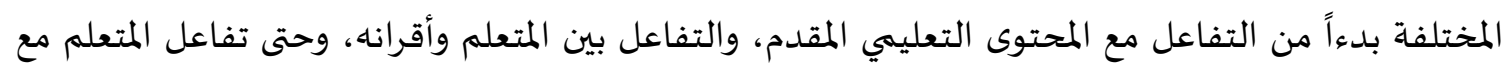

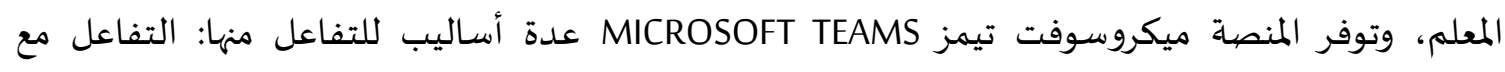


المحتوى، وذلك بواسطة الروابط الداخلية الموجودة في المحتوى، وتحميل الملفات، والضغط على روابط

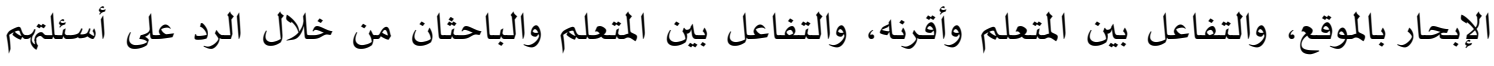

واستفساراتهم.

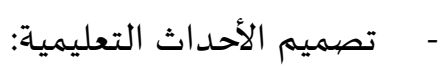

في هذه المرحلة تم تجزئة مهام التعلم وأهدافه الرئيسة (الأهداف العامة) والتي يجب على المعلمين انجازها

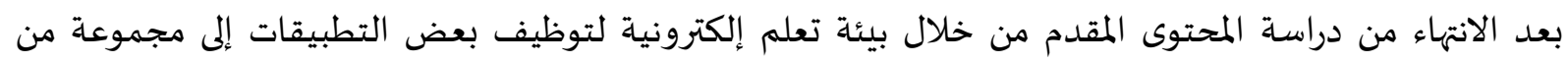

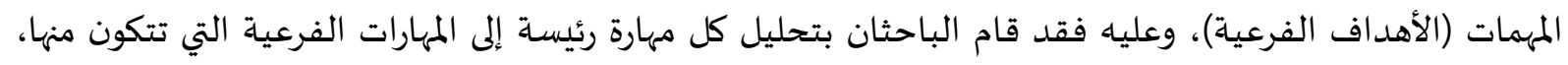

$$
\text { واستخدم الباحثان أسلوب التحليل الهرمي من أعلى إلى أسفل. والمان. }
$$

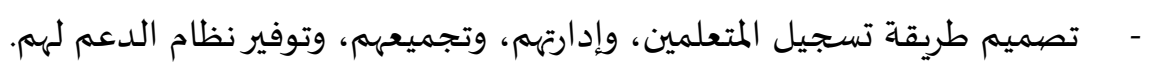

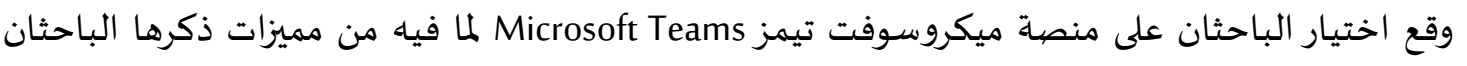

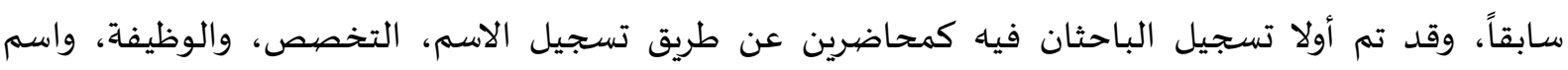

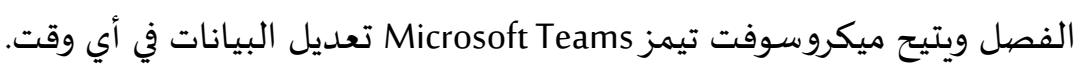

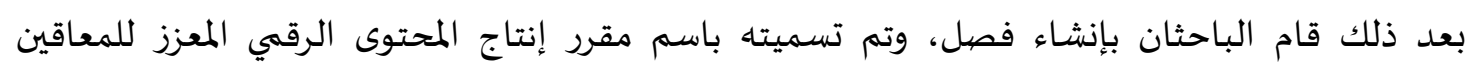

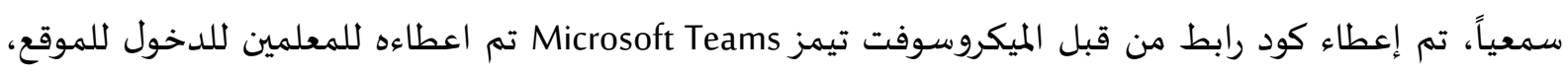

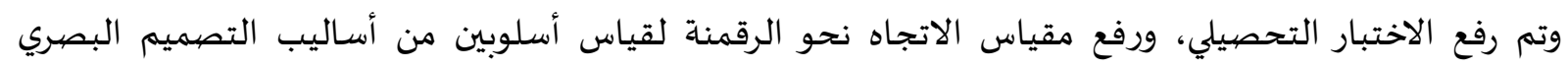

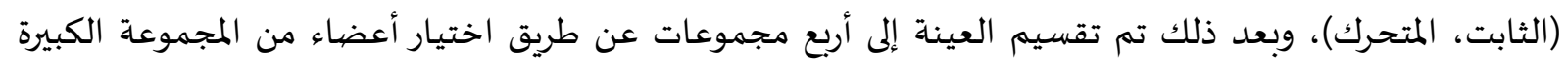

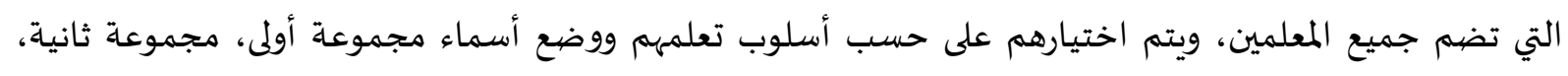
مجموعاة ثالثة، مجموعة رابعة كالتالي:

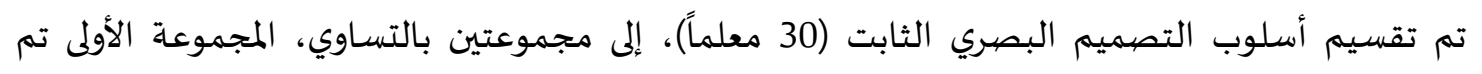

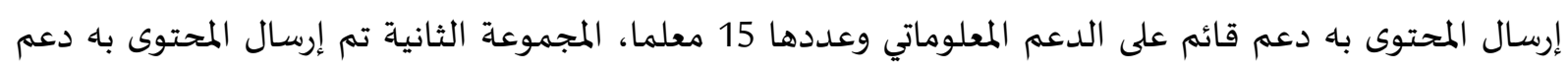
قائم على الدعم الإجرائي وعددها 15 معلما. تم تقسيم أسلوب التصميم البصري المتحرك (30 معلماً)، إلى مجموعتين بالتساوئي المعاوي: المجموعة الثالثة تم إرسال المحتوى باه نمط الدعم المعلوماتي وعددها 15 معلماً.

المجموعة الرابعة تم إرسال المحتوى باه نمط الدعم الإجرائي وعددهائ وعا 15 15معلماً.

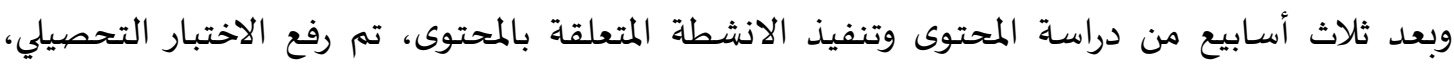

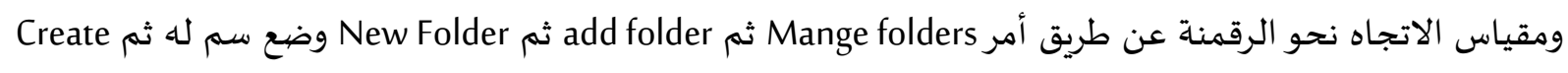

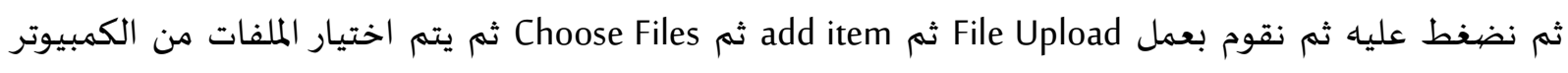

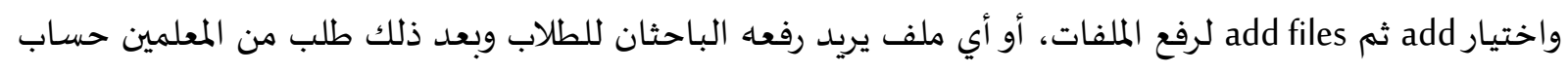

$$
\text { - من تعلمهم بالساعات الحساب كفاءة التعلم. }
$$

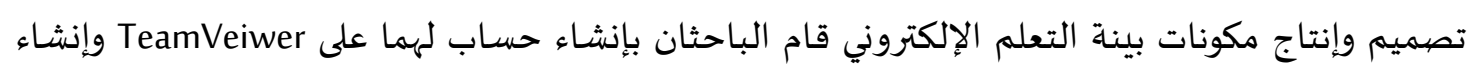

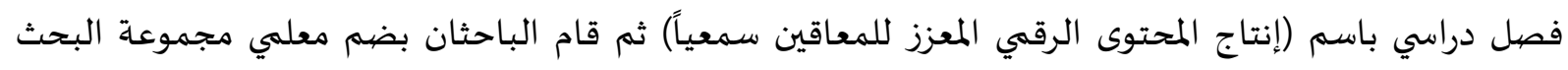

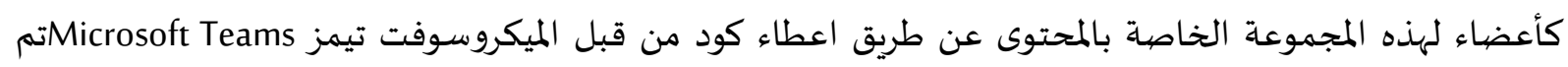
اعطاءه للمعلمين للدخول للموقع. 
تصميم المحتوى واستراتيجيات تنظيمها: قام الباحثان بإعداد الموضوع التعليمي الخاص بمهارات إنتاج المحتوى

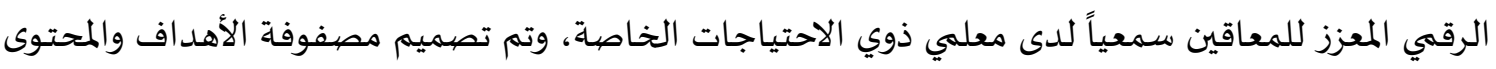

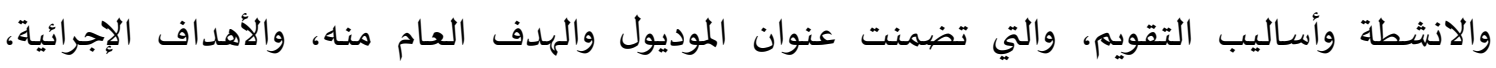
والانشطة وأساليب التقويم. واسيط. وقد قام الباحثان في هذه الخطوات بتنظيم عناصر المحتوى وفقاً لتسلسل منطقي حسب ترتيب الأهداف

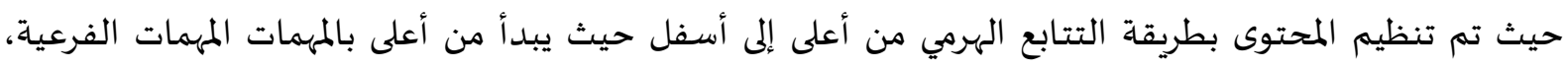

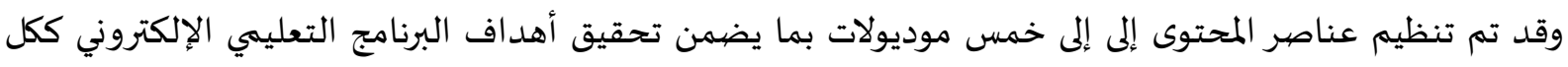

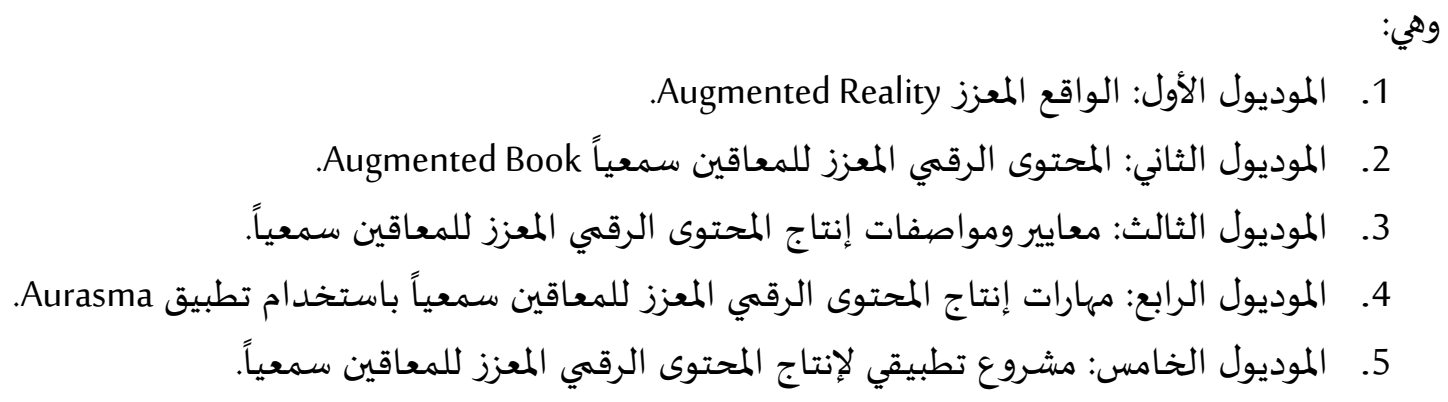

ثالثا: مرحلة الإنتاج:

- الحصول على الوسائط وإعداد التسهيلات: قام الباحثان بتحديد التطبيقات التي تم توظيفها داخل البيئة والتي

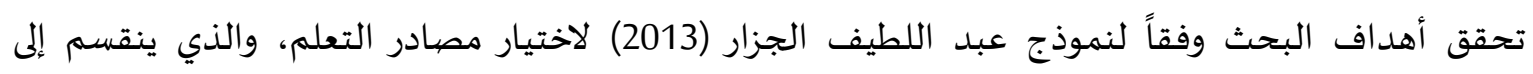

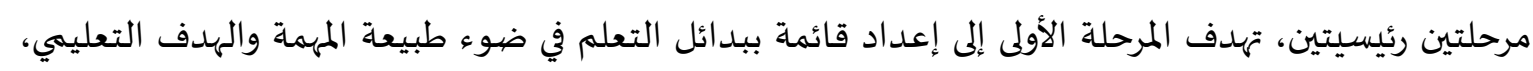

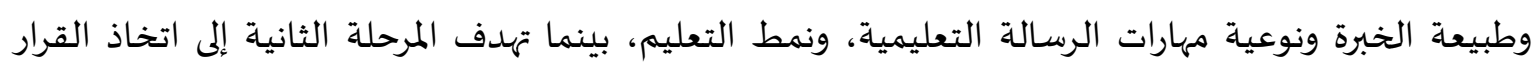

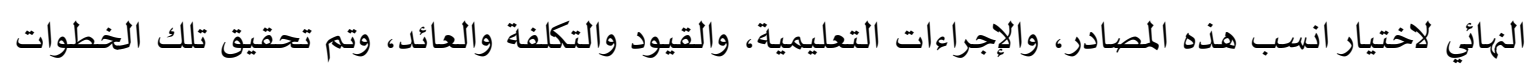

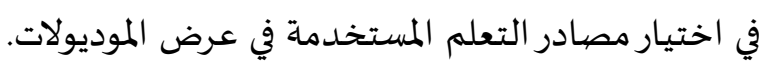
وصف المصدر التعليمي: في هذه المرحلة قام الباحثان بتحديد المعايير الواجب مراعاتها في تصميم وإنتاج مصادر المردي

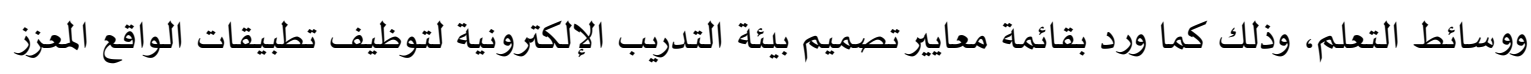
التي أعدها الباحثان. اتخاذ القرار بشأن الحصول على المصادر: تم تصميم أغلب المصيادر مثل ملفات الوسائط المتعددة وملفات الفيديو والصور من إنتاج الباحثان.

رابعاً: مرحلة التقويم : Evaluation: وتضمنت هذه المرحلة:

تجريب مصغر لعمل تقويم بنائي على عينة استطلاعية مكونة من ثلاث معلمين لتقييم بيئة التدريب الإلكتروني،

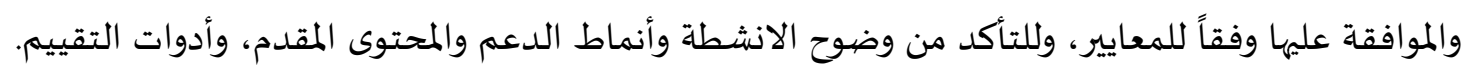

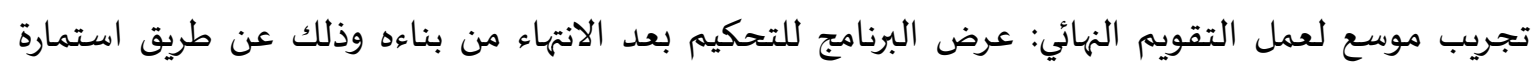

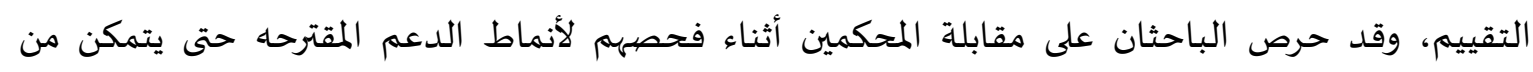

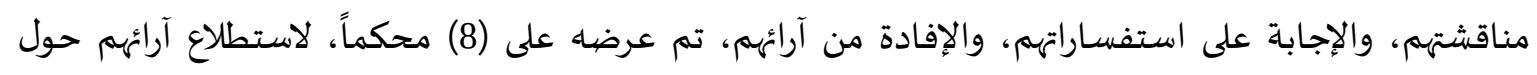

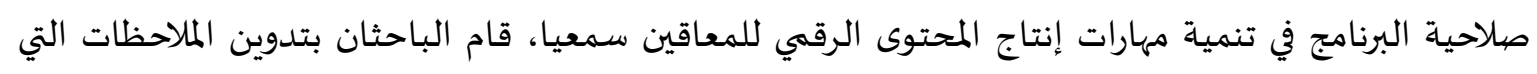


تم استخلاصها من التجربة الاستكشافية بشأن مواقع التدربب الثلاثة، وبناءً علية قام الباحثان بإجراء

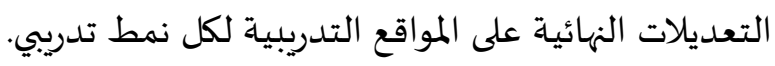

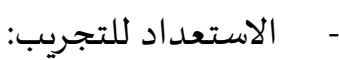

$$
\text { قام الباحثان بالإجراءات التالية استعداداً لإجراء تجربة البحث: }
$$

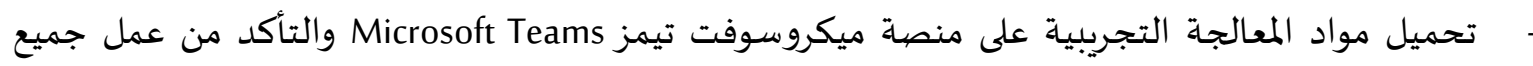

$$
\text { الروابط عليها. }
$$

- عقد جلسة تمهيدية مع أفراد العينة؛ لتعريفهم بماهية أنماط الدعم الإلكتروني وكيفية استخدامها.

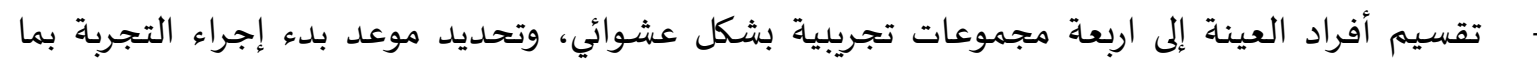

$$
\text { يتناسب مع ظروف عملهم بالمدرسة. }
$$

$$
\text { مرحلة الاستخدام: وقد اشتملت هذه المرحلة على الخطوات التالي: }
$$

- ـ التعديل بالدمج والنسخ: قام الباحثان في نمطي الدعم الإلكتروني لتحقيق التعديلات ذات ذات الأهمية التي

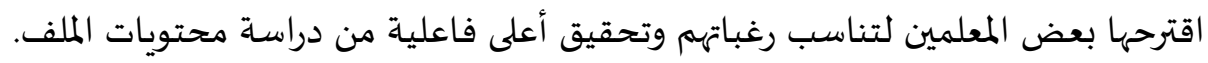

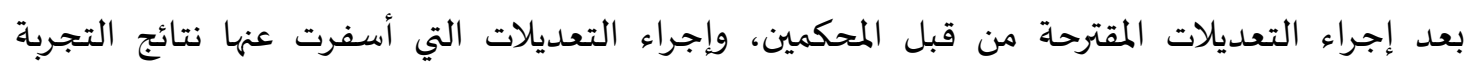

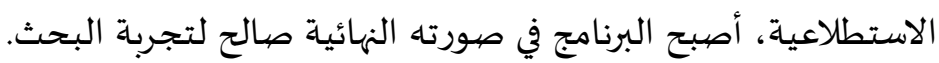

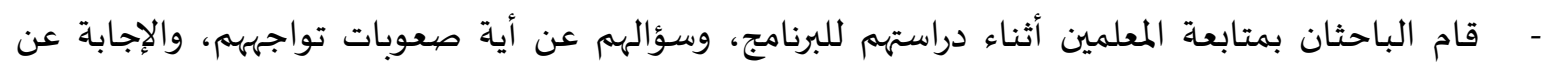
استفساراتهم. - اعتمد التقويم في المديولات التعليمية على التقويم المستمر (قبلي- بنائي- نهائي) طوال مدة دراسة المديولات، وعلى مدار مراحل طرق واستراتيجيات التدريس المستخدمة، ذلك من خلال أساليب تعتمد تقويم الإلكتروني

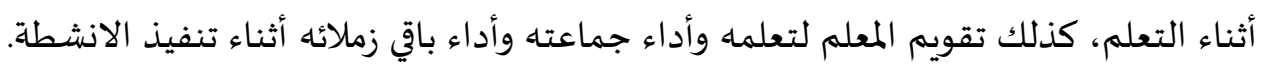

$$
\text { منهجية البحث وبناء أدوات البحث : }
$$

هدف البحث الحالي إلى تنمية مهارات إنتاج المحتوى الرقمي المعزز للمعاقين سمعياً والاتجاه نحو الرقمنة

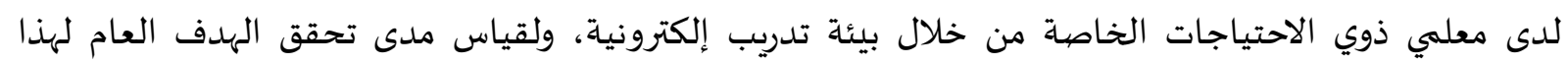
البحث قام الباحثان بإعداد كل من الأدوات التالية: التاتية

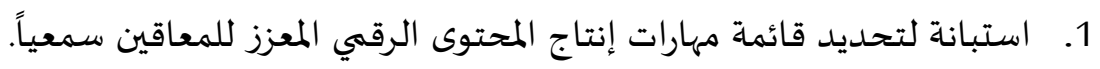

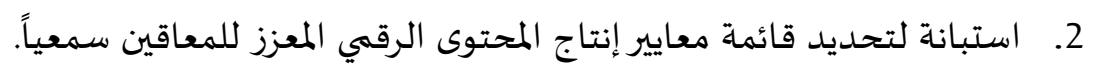

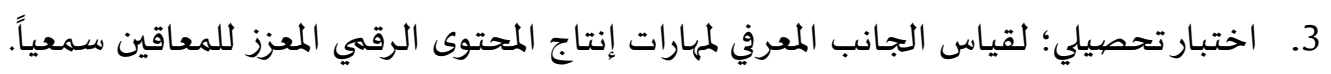
4. بطاقة تقييم المنتج للمحتوى الرقمي المعزز للمعاقين سمعياً. 5. مقياس اتجاهات المعلمين نحو الرقمنة.

وفيما يلي عرض تفصيلي لخطوات بناء تلك الأدوات.

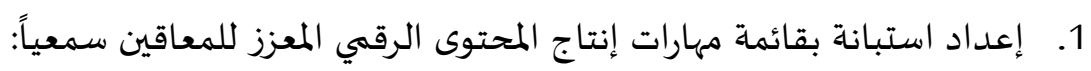

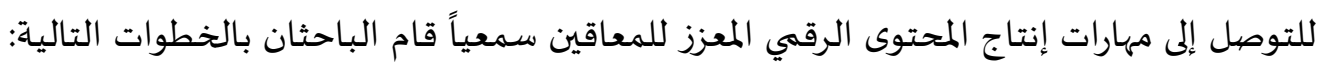

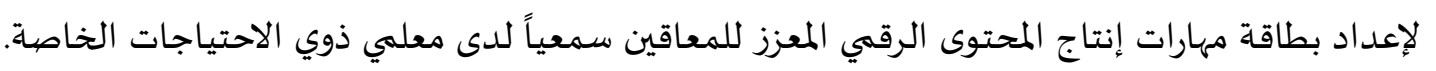


تحديد الهدف من قائمة المهارات: هدفت هذه البطاقة إلى تحديد مهارات إنتاج المحتوى الرقهي المعزز

للمعاقين سمعياً لدى معلمي ذوي الاحتياجات الخاصة.

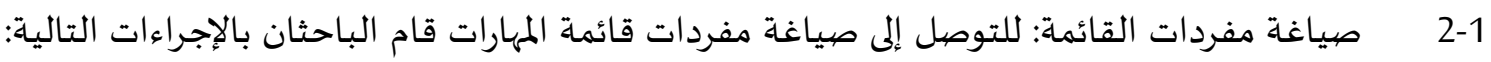

الاطلاع على الأدبيات والدراسات السابقة التي تناولت تصميم وتطويره المحتوى الرقهي المعزز بصفه عامة

والمعاقين سمعياً بصفة خاصية.

تحليل مهارات تصميم وإنتاج نماذج الواقع المعزز، وقد تبين للباحثين وجود . أمهارات رئيسة يتفرع منها

124 مهارة فرعية.

الاطلاع على مجموعة من الأدبيات والدراسات السابقة التي تناولت الواقع المعزز وتطبيقاته.

الاطلاع على مجموعة من الموضوعات الحديثة المنشورة إلكترونيا على المواقع والمدونات والمجلات الإلكترونية

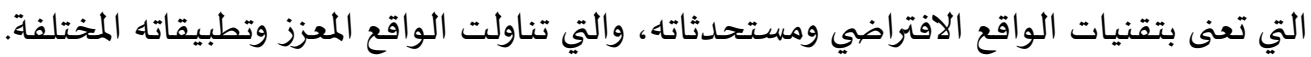
فحص منصة Google للتطبيقات Google Play وذلك بهدف الاطلاع على تطبيقات الواقع المعزز المختلفة التي يمكن من خلالها تحقيق أهداف البحث، ووقع اختيار الباحثان على تطبيق Aurasma وقد اختار الباحثان هذا التطبيق للأسباب التالية:

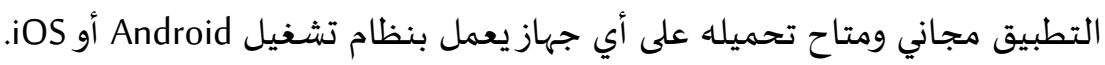

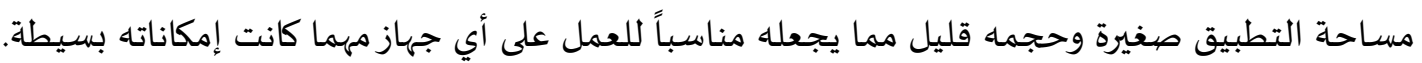

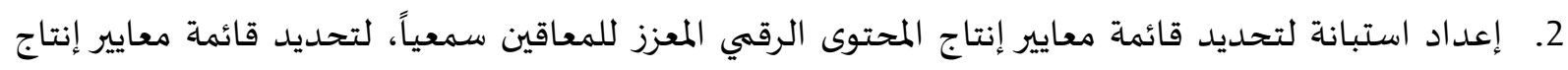

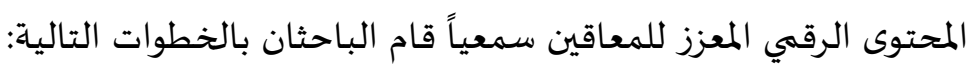

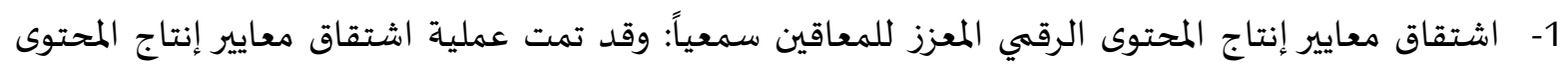

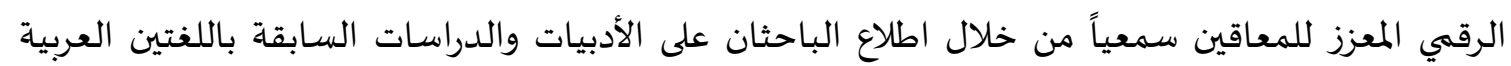
والانجليزية في ثلاثة محاور :

المحور الأول: الأدبيات والدراسات السابة فابة التي تناولت تصيميم وإنتاج المحتوى الرقهي المدرسي؛ حيث أن المحتوى الرقهي المعزز للمعاقين سمعياً هو محتوى ورقي مزود بعلامات الربط البرمجي (Quick Response-QR) بعناصر الواقع المعزز الرقمية.

المحور الثاني: الأدبيات والدراسات السابقة التي تناولت تصميم وإنتاج الواقع المعزز وشروطه ومعاييره. المحور الثالث: الأدبيات والدراسات السابقة التي تناولت المواصفات واتيات التربوية والفنية لتصيميم وإنتاج الوسائط المتعددة الرقمياة، والتي هي المادة الخام لعناصر التعزيز التي يتم ربطها برمجياً بعلامات الواقع المعزز.

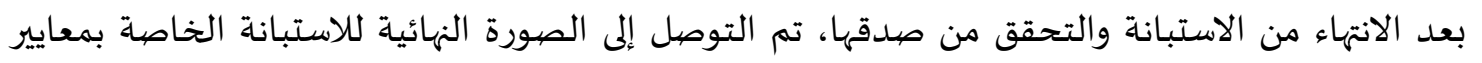
إنتاج المحتوى الرقهي المعزز، والتي اشتملت على مجالين تفرعا إلى 9 معايير رئيسة بواقع 7 في المجال الأول التهل (التربوي)

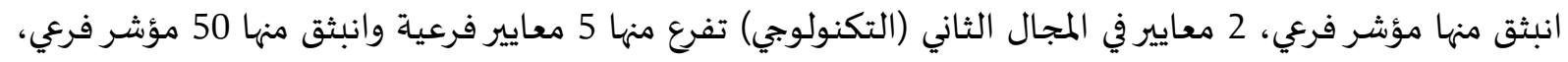

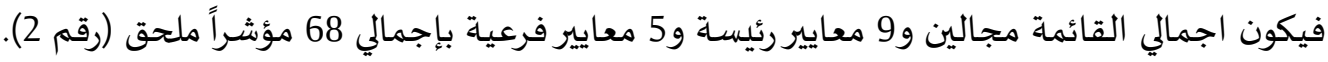

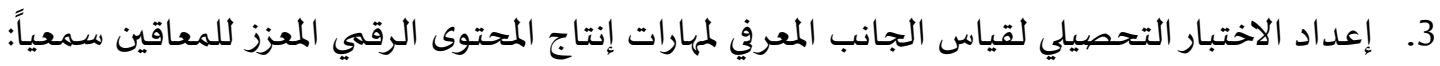

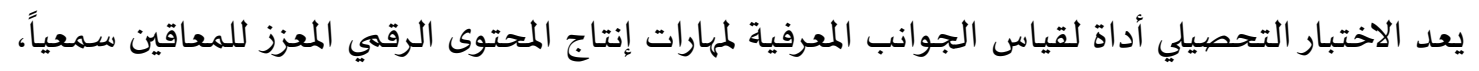

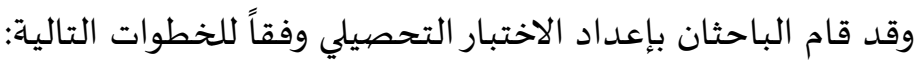


1- تحديد الهدف من الاختبار التحصيلي: هدف هذا الاختبار إلى قياس مستوى تحصيل المعلمين في الجانب

$$
\text { المعرفي لمهارات إنتاج المحتوى الرقهي المعزز للمعاقين سمعياً. }
$$

2- الصورة الأولية للاختبار التحصيلي: تم تحديد المفردات المرتبطة بكل مستوى من المستويات المعرفية الثلاثة:

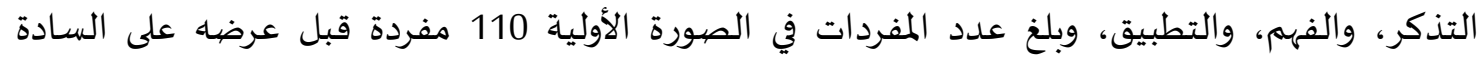

3- تحديد نوع مفردات الاختبار التحصيلي وصياغتها: اعتمد الباحثان في صياغته لمفردات الاختبار التحصيلي

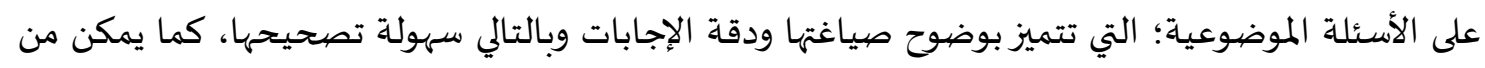

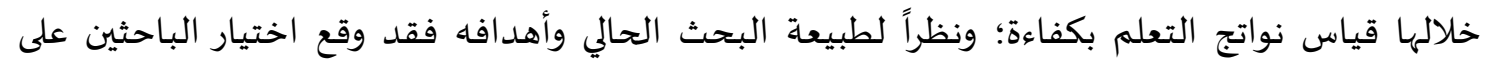

نوعين من الأسئلة الموضوعية هما:

$$
\text { 1. }
$$

3. وقد راعى الباحثان الشروط الواجب اتباعها عند صياغة مفردات الاختبار التحصيلي، من حيث صياغة

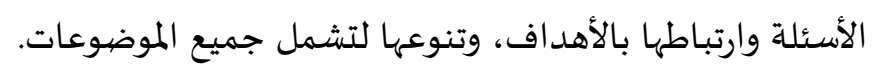

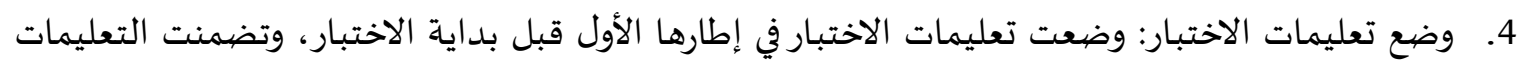

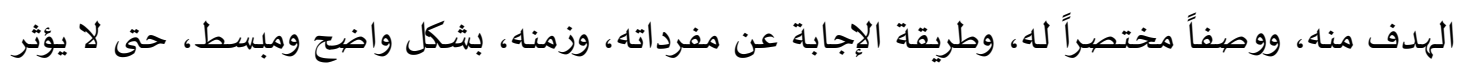

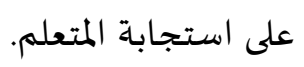

5. تقدير الدرجات وطريقة التصحيح: قام الباحثان بتصميم الاختبار إلكترونياً، بحيث يتم التصحيح إلكترونياً

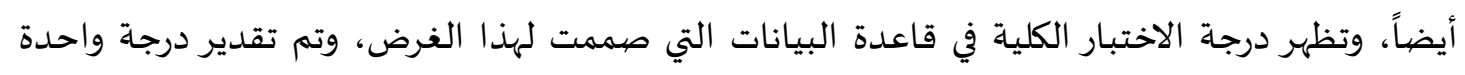

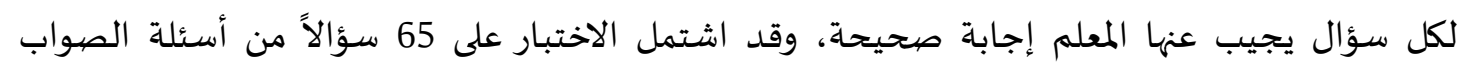
والخطأ، و45 سؤالاً من أسئلة الاختيار من متعدد، ليصبح مجموع درجات إجابة الاختبار التحصيلي 110 سؤالاً في صورته الأولية.

6. التحقق من صدق وثبات الاختبار التحصيلي: قام الباحثان بالتحقق من صدق وثبات الاختئبار التحصيلي كالتالي:

التحقق من صدق الاختبار التحصيلي: اعتمد الباحثان على صدق المحكمين الذي يعد من أهم طرق إق إقدئ

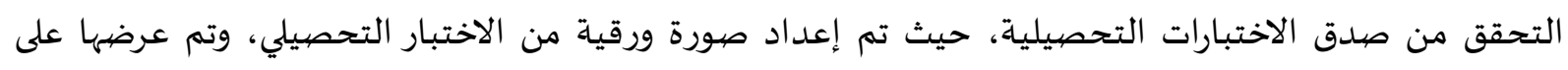

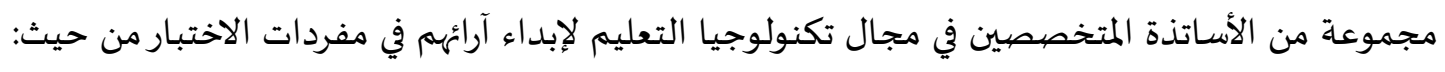
دقة الصياغة اللغوية لكل مفردة من مفردات الاختبار.

$$
\text { مدى ارتباط مفردات الاختبار بالأهداف التعليمية. }
$$

تعديل ما يحتاج إلى التعديل من المفردات بالحذف أو الإضافة أو التعديل.

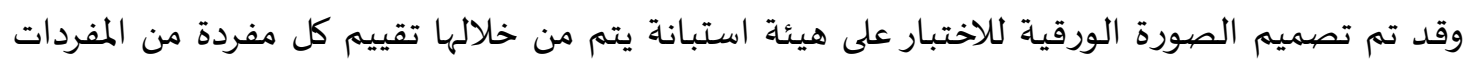
وفقا للاستجابتين:

$$
\begin{aligned}
& \text { تقييم المفردة (صياغتها اللغوية، ارتباطها بالهدف). } \\
& \text { ملاحظات يقترح إضافتها. } \\
& \text { وذلك وفقا للإجراءات التالية: }
\end{aligned}
$$


أ- حساب الاتساق الداخلي للاختبار: تم التحقق من صدق الاختبار من خلال حساب معاملات الارتباط بين كل

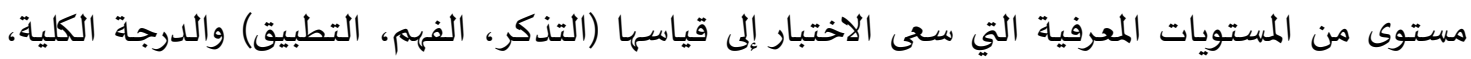

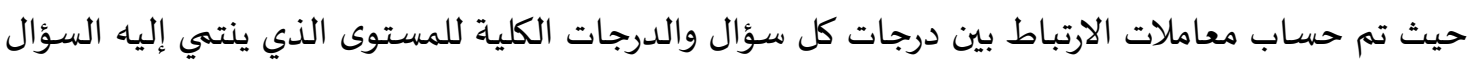

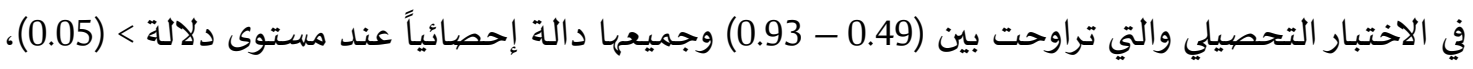

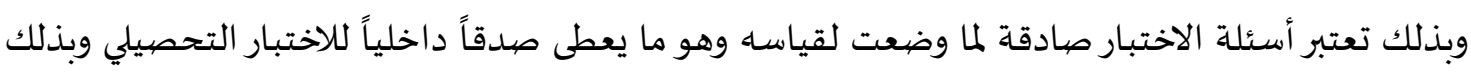

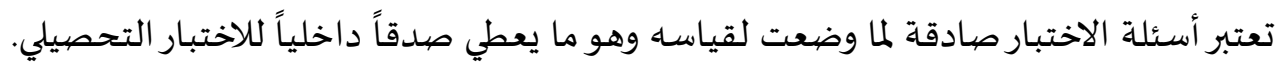

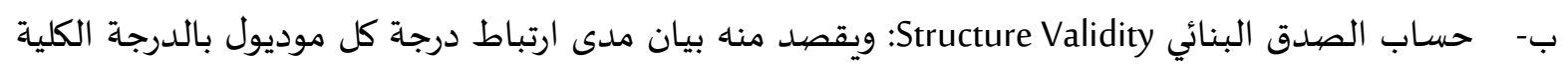
للاختبار كما في جدول (1).

جدول (1) بيان مدى ارتباط درجة كل موديول بالدرجة الكلية للاختبار

\begin{tabular}{|c|c|c|c|}
\hline المستوى & التطبيق & \\
\hline
\end{tabular}

يبين الجدول السابق معاملات الارتباط بين الدرجات الكلية لكل مستوى والدرجات الكلية للاختبار

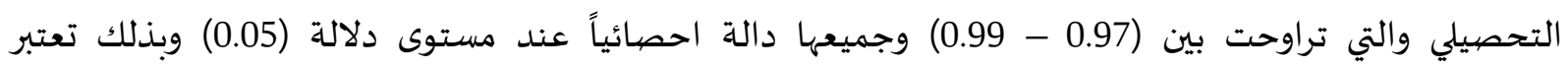

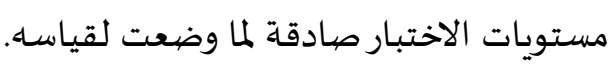
ج- نتائج ثبات (Reliability) الاختبار التحصيلي: يقصديد بثبات الاختبار أن يعطي نفس النتيجة لو تم تم إعادة تطبيقه أكثر من مرة تحت نفس الظروف والشروط، وقد تحقق الباحثان من ثبات الاختبار من خلال طريقة

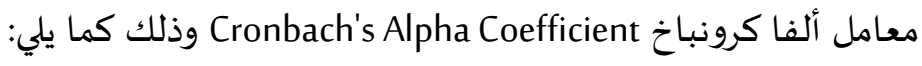
جدول (2) نتائج اختبار ألفا للاختبار التحصيلي

\begin{tabular}{|c|c|c|}
\hline معامل ألفا كرونباخ & عدد الأسئلة & المستوى \\
\hline 0.97 & 44 & التذكر \\
\hline 0.94 & 32 & 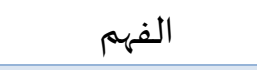 \\
\hline 0.95 & 27 & التطبيق \\
\hline 0.98 & 103 & الاختبار التحصيلي \\
\hline
\end{tabular}

يبين الجدول السابق معاملات الثبات لمستويات الاختبار التحصيلي التي تراوحت بين (0.94 - 0.97) بالنسبة لمستويات الاختبار وبلغ معامل الثبات للاختبار ككل (0.98) وهي نسب ثبات مرتفعة مما يطمئن الباحثان لنتائج

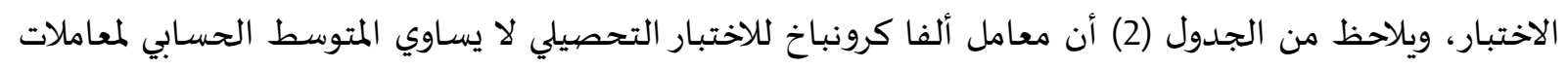

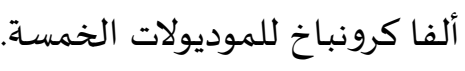

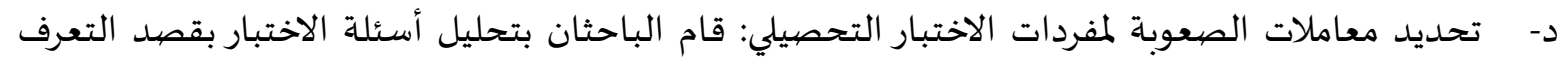

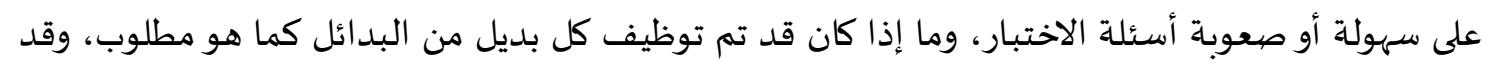
ظهر من الجدول أن قيم معامل الصعوبة لأسئلة الاختبار التحصييلي قد تراوحت بين (0.20 - 0.43) ويعتبر

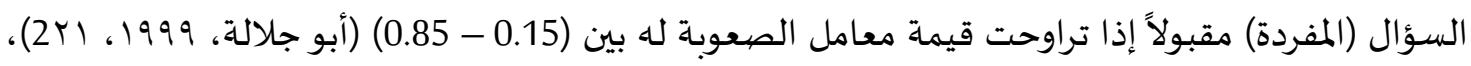

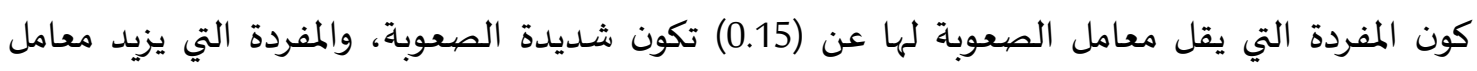

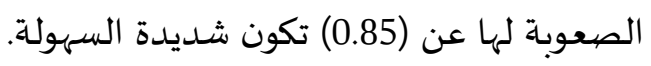


هـ- تحديد معاملات التمييز لمفردات الاختبار التحصيلي: يشير معامل التمييز إلى قدرة كل مفردة من مفردات

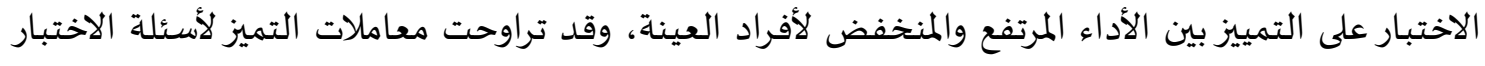

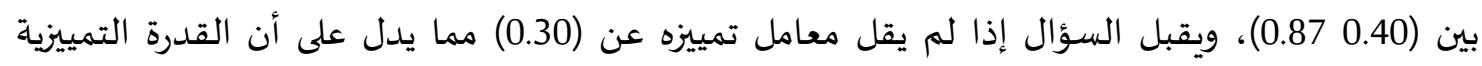
لأسئلة الاختبار مناسبة. و- حساب زمن الاختبار: تم حساب زمن الاختبار بحساب متوسطات الأزمنة التي قضاها طلاب الابـابل العينة الاستطلاعية للإجابة عن أسئلة الاختبار وتم التوصل إلى الزمن اللازم وهو (45 دقيقة)، وقد تم الإن الإلتزام باه عند التصميم الإلكتروني للاختبار التحصيلي للعينة الأساسية.

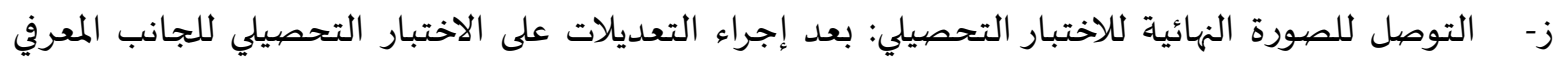

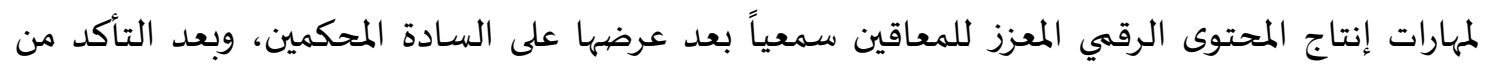

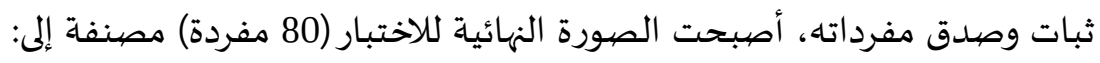

$$
\text { (50 مفردة) لأسئلة الصواب والخطأ. }
$$

معامل السهولة والصعوبة والتمييز لمفردات الاختبار: بعد عرض الاختبار المعرفي على السادة الخبراء، قام الباحثان بتطبيق الاختبار التحصييلي لمهارات إنتاج

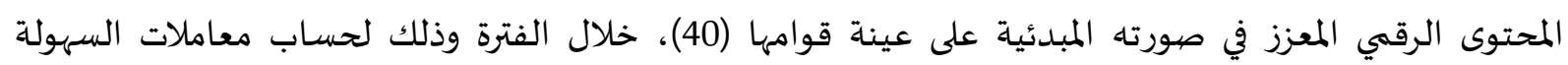
والصعوبة لمفردات الاختبار باستخدام المعادلة التالية: عدد الأفراد الذين أجابوا إجابة صحيحة على كل مفردة

$$
\text { معامل السهولة = n = }
$$

عدد الأفراد الكلي

والعلاقة بين معامل السهولة ومعامل الصعوبة علاقة عكسية، بمعنى أن مجموعهم يساوي الواحد

$$
\text { الصحيح كالتالي: معامل السهولة = 1- معامل الصعوبة }
$$

معامل التمييز:

لحساب معامل التمييز، رتبت درجات العينة تنازليا، لتحديد الـ27\% العليا وكذلك الـ27\% السفلى، بهدف تحديد معامل التميز لكل مفردة باستخدام المعادلة التالية: عدد الإجابات الصحيحة في المجموعة العليا - عدد الإجابات الصحيحة في المجموعة السفلي

$$
\text { عدد المبحوثين في إحدى المجموعتين }
$$

وقد تم قبول المفردات التي يتوفر فيها الشرطين التاليين:

-

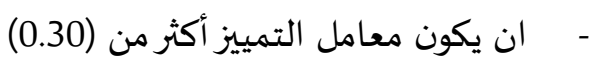

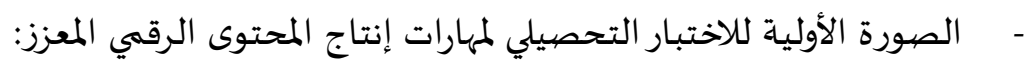


بعد عرض مفردات الاختبار على السادة الخبراء وإيجاد معاملات الصعوبة والتمييز تم حذف (7) مفردات

وفقاً لمعاملي الصعوبة والتمييز"، وبذلك أصبح الاختبار التحصيلي لمهارات إنتاج المحتوى الرقهي المعزز يتضمن (80)

روعي عند تصحيح الاختبار أن تعطى درجة واحدة لكل إجابة صحيحة من عبارات الصواب والخطأ والاختيار من متعدد، وصفر لكل إجابة خاطئة، وقد تم إعداد مفتاح التصحيح لتسهيل عملية التصحيح.

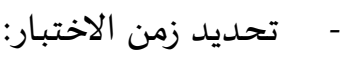

قام الباحثان بتحديد الزمن المناسب للإجابة على الاختبار في ضوء نتبارئج التطبيق على الحكام من المعادلة

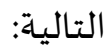
الزمن الذي استغرقه أول مختبر + الزمن الذي استغرقه آخر مختبر

زمن الاختبار=

وبذلك أمكن تحديد الزمن الكلي للاختباروهو (45) دقيقة.

المعاملات العلمية للاختبار التحصيلي لمهارات إنتاج المحتوى الرقمي المعزز:

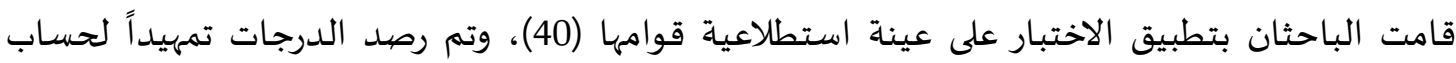
المعاملات الإحصائية والعلمية للاختبار.

صدق الاختبار التحصيلي لمهارات إنتاج المحتوى الرقمي المعزز:

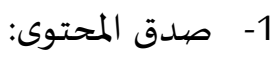

قام الباحثان بحساب نسب اتفاق المحكمين وعددهم (7) على كل مفردة من مفردات الاختبار من حيث:

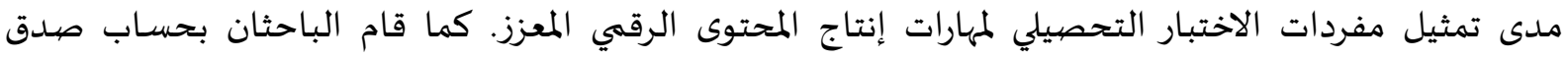

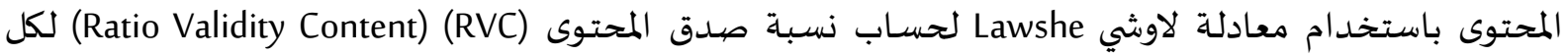
مفردة من مفردات الاختبار، ويوضيح الجدول الآتي نسب اتفاق المحكمين ومعامل صديد لاتوشي للاختبار التحصيلي لمهارات إنتاج المحتوى الرقمي المعزز مفردات

جدول (3) متوسطات نسب الاتفاق بين المحكمين

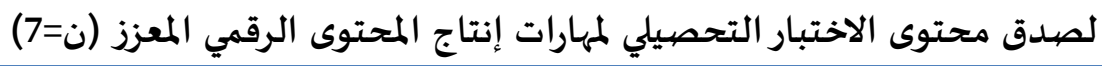

\begin{tabular}{|c|c|c|c|c|c|c|c|}
\hline معامل صلدق & المفردة & معامل صبدق لاوشي & المفردة & معامل صبدق لاوشي & المفردة & معامل صلدق لاوشي & المفردة \\
\hline 0.71 & 64 & 0.71 & 43 & 1 & 22 & 1 & 1 \\
\hline 0.71 & 65 & 0.71 & 44 & 0.71 & 23 & 0.71 & 2 \\
\hline 1 & 66 & 1 & 45 & 0.71 & 24 & 0.71 & 3 \\
\hline 0.71 & 67 & 0.71 & 46 & 1 & 25 & 1 & 4 \\
\hline 0.71 & 68 & 0.71 & 47 & 0.71 & 26 & 1 & 5 \\
\hline 1 & 69 & 1 & 48 & 0.71 & 27 & 0.71 & 6 \\
\hline 0.71 & 70 & 0.71 & 49 & 1 & 28 & 0.71 & 7 \\
\hline 1 & 71 & 1 & 50 & 0.71 & 29 & 1 & 8 \\
\hline 0.71 & 72 & 0.71 & 51 & 1 & 30 & 0.71 & 9 \\
\hline
\end{tabular}


المجلة العربية للطوم ونشر الأبحاث ـ مجلة العلوم التريوية والنفسية ـ المجلد الخامس ـ العدد الخامس والعثرون ـ يوليو 2021م

\begin{tabular}{|c|c|c|c|c|c|c|c|}
\hline معامل صدق لاوشي & المفردة & معامل صيدق لاوشي & رقمرة & معامل صلدق & رقمثم & معامل صلدق لاوشي & المفردة \\
\hline 1 & 73 & 1 & 52 & 0.71 & 31 & 0.71 & 10 \\
\hline 1 & 74 & 0.71 & 53 & 1 & 32 & 1 & 11 \\
\hline 0.71 & 75 & 0.71 & 54 & 0.71 & 33 & 0.71 & 12 \\
\hline 0.71 & 76 & 1 & 55 & 0.71 & 34 & 0.71 & 13 \\
\hline 1 & 77 & 0.71 & 56 & 0.71 & 35 & 1 & 14 \\
\hline 0.71 & 78 & 0.71 & 57 & 1 & 36 & 0.71 & 15 \\
\hline 1 & 79 & 1 & 58 & 0.71 & 37 & 1 & 16 \\
\hline 0.71 & 80 & 1 & 59 & 0.43 & 38 & 1 & 17 \\
\hline & & 0.71 & 60 & 1 & 39 & 0.71 & 18 \\
\hline & & 1 & 61 & 0.71 & 40 & 1 & 19 \\
\hline & & 0.43 & 62 & 0.43 & 41 & 0.71 & 20 \\
\hline & & 0.71 & 63 & 1 & 42 & 0.43 & 21 \\
\hline & & \multicolumn{2}{|c|}{0.81} & \multicolumn{4}{|c|}{ نسبة صدق المحتوى للاختبار ككل } \\
\hline
\end{tabular}

يتضح من الجدول (3) أن نسبة صدق المحتوى لمفردات الاختبار التحصيلي لمهارات إنتاج المحتوى الرقهي

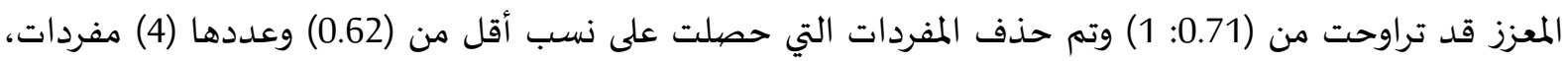

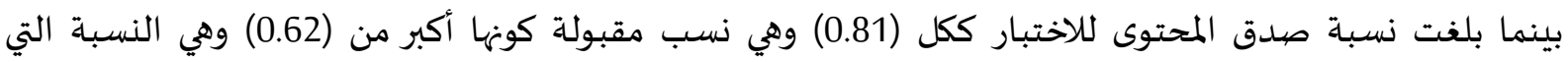

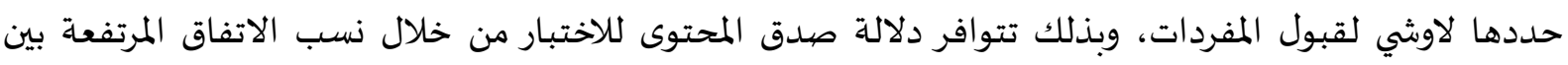

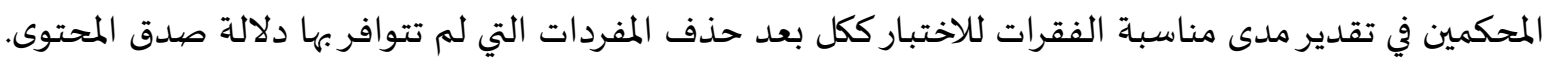

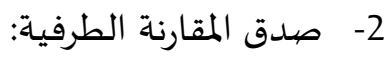

استعان الباحثان بصدق المقارنة الطرفية للاختبار التحصيلي لمهارات إنتاج المحتوى الرقهي المعزز قيد

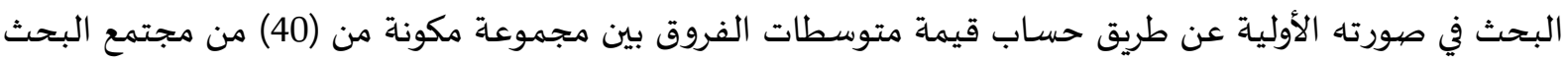
وخارج العينة الأساسية وتم ترتيب الدرجات تنازلياً وأخذ درجات أعلى 10..... كربيع أعلى ودرجات أقلى أقل 10....... كربيع

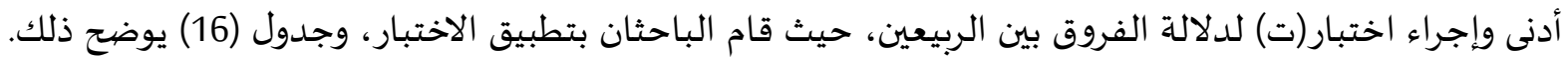

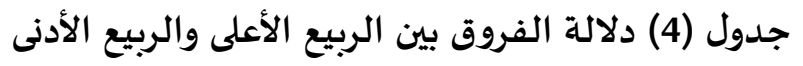

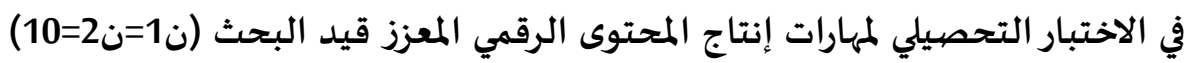

\begin{tabular}{|c|c|c|c|c|c|c|c|}
\hline \multirow{2}{*}{ مستوى الدلالة } & \multirow{2}{*}{ قيمة "ت" } & \multirow{2}{*}{ المترق بين } & \multicolumn{2}{|c|}{ الربيع الأدنى } & \multicolumn{2}{|c|}{ الربيع الأعلى } & \multirow{2}{*}{ المتغير } \\
\hline & & & $\varepsilon$ & 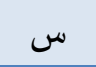 & $\varepsilon$ & س - س & \\
\hline 0.00 & 11.67 & 12 & 1.14 & 3.80 & 3.05 & 15.80 & الاختبار التحصيلي \\
\hline
\end{tabular}

يتضح من جدول (4) وجود فروق دالة إحصائيا بين الربيع الأعلى والربيع الأدنى للاختبار التحصيلي حيث التبثي

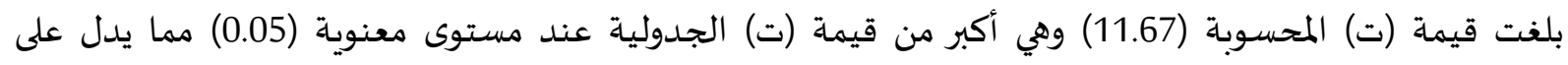

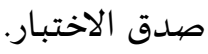


ثبات الاختبار التحصيلي لمهارات إنتاج المحتوى الرقمي المعزز:

ثبات التطبيق وإعادة التطبيق

كما استخدم الباحثان طريقة تطبيق الاختبار وإعادة تطبيقه على عينة قواهها (40) الذين تم استخدامهيم

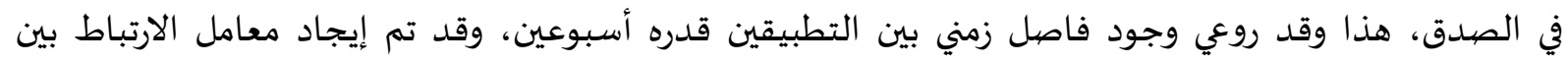

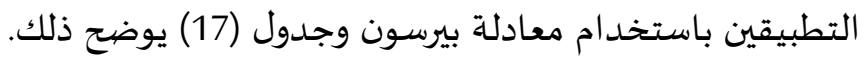

جدول (5) معامل الارتباط بين التطبيقين الأول والثاني

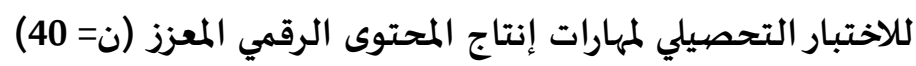

\begin{tabular}{|c|c|c|c|c|c|c|}
\hline \multirow{2}{*}{ قيمة ر } & \multirow{2}{*}{ قيمة "ر" } & \multicolumn{2}{|c|}{ التطبيق الثاني } & \multicolumn{2}{|c|}{ التطبيق الأول } & \multirow{2}{*}{ المتغير } \\
\hline & & $\varepsilon$ & س & $\varepsilon$ & س & \\
\hline 0.30 & 0.88 & 4.20 & 10.73 & 4.57 & 10.25 & الاختبار التحصيلي \\
\hline
\end{tabular}

يتضح من جدول (5) وجود ارتباط دال إحصائيا بين التطبيقين الأول والثاني في الاختبار التحصيلي لمهارات

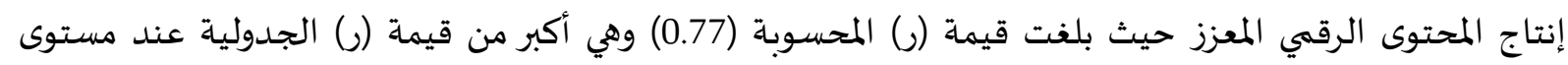
معنوية "0.05" مما يعطي دلالة مباشرة على ثبات الاختبار، وبذلك تمكن الباحثان من التوصل إلى الماتل الاختبار

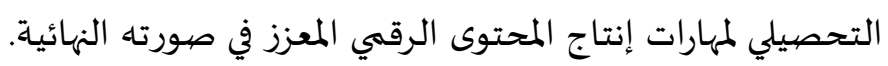
4. بطاقة تقييم المنتج للمحتوى الرقهي المعزز للمعاقين سمعياً:

1- - تحديد الهدف من بطاقة تقييم المنتج للمحتوى الرقي المعزز للمعاقين سمعياً: تهدف البطاقة إلى تقييم

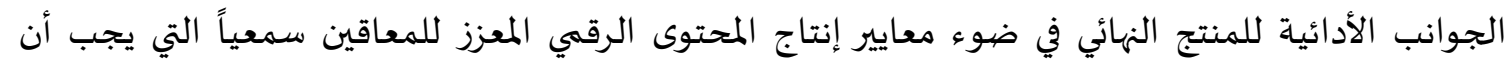
تتوافر في المنتج النهائي. 2- تحديد محتوى بطاقة المنتج للمحتوى الرقي المعزز للمعاقين سمعياً: اعتمد الباحثان في تحديد محتوى

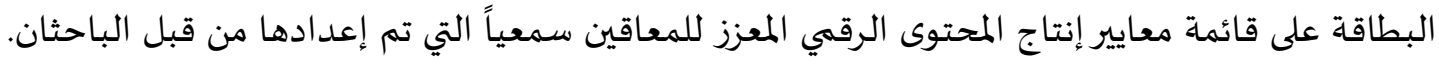

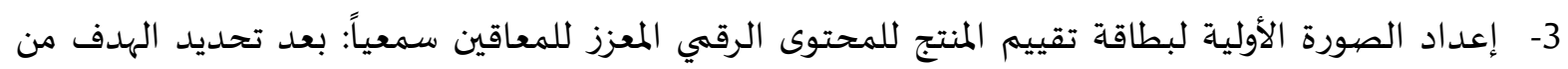

البطاقة، تم تحليل المحاور الرئيسة للبطاقة إلى (9) معايير رئيسة، تم تصنيفها إلى (68) معياراً فرعياً.

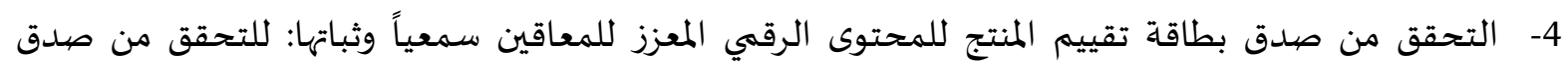
وثبات البطاقة اتبع الباحثان الطريقتين التاليتين:

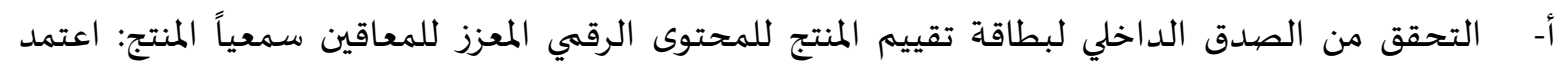

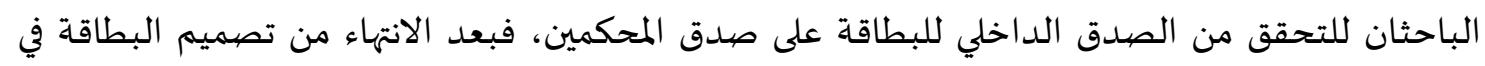

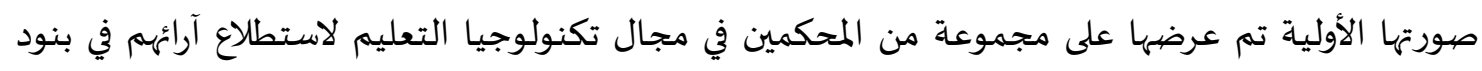

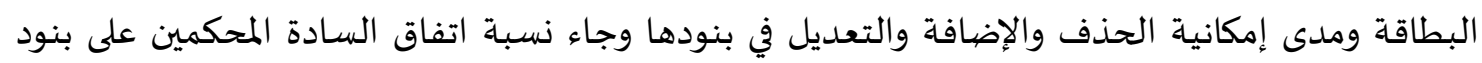
البطاقة بنسبة (98.4\%). ب- - التحقق من ثبات بطاقة تقييم المنتج للمحتوى الرقمي المعزز للمعاقين سمعياً: قام الباحثان بالتأكد من بن ثبات البطاقة عن طريق حساب معادلة ألفا كرونباخ حيث تم حساب كل معيار من المعايير الرئيسة بالمقارنة

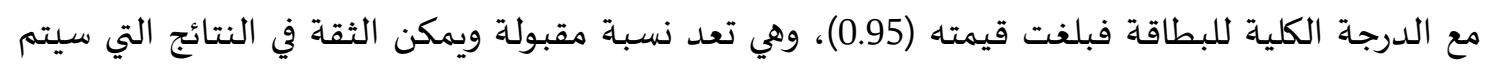
الحصول عليها عند تطبيق بطاقة التقييم على العينة الأساسية للبحث. 


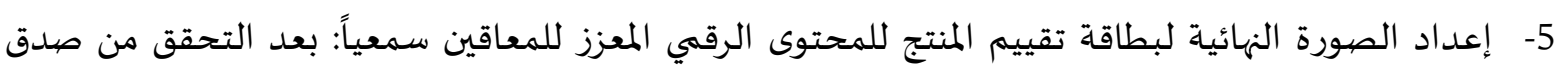

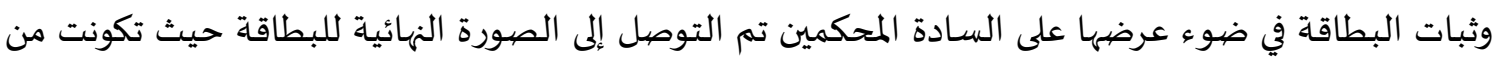

$$
\text { (9) معايير رئيسة يتفرع منها (68) مؤشراً. }
$$

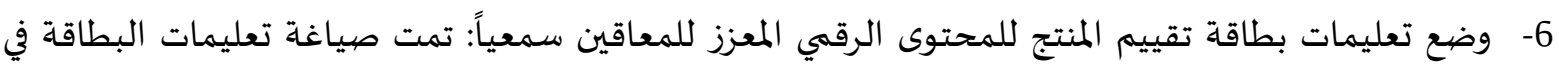

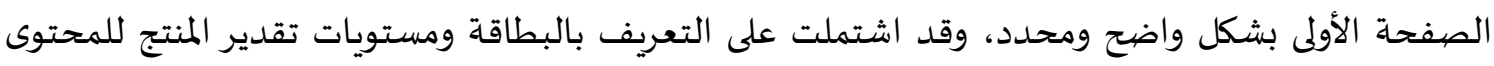

$$
\text { الرقهي المعزز للمعاقين سمعياً. }
$$

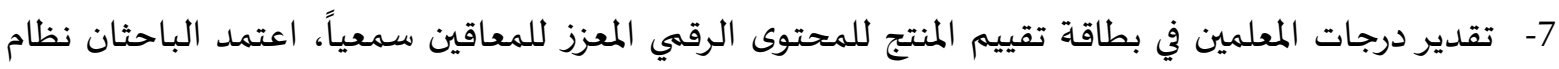

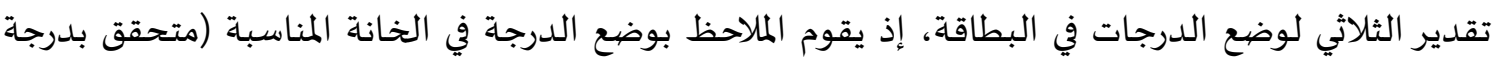

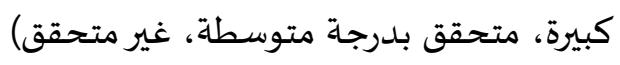

إذا توافر في المحتوى الرقي المعزز للمعاقين سمعياً المنتج المؤشر بدرجة كبيرة يحصل الطالب على درجتين. إذا توافر في المحتوى الرقي المعزز للمعاقين سمعياً المنتج المؤشر بدرجة متوسطة يحصل الطالب على درجة

واحدة.

إذا لم يتوافر في المحتوى الرقهي المعزز للمعاقين سمعياً المنتج المؤشر لا يحصل الطالب على درجة ويسجل

صفر.

بطاقة تقييم المحتوى: المعاملات العلمية بطاقة تقييم المحتوى:

قام الباحثان بتطبيق بطاقة تقييم المحتوى على عينة استطلاعية قوامها (40)، وتم رصديد الدرجات تمهيداً

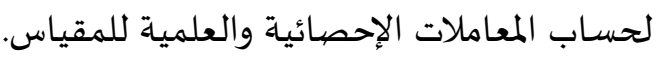

صداق بطاقة تقييم المحتوى:

قام الباحثان بحسـاب نسب اتفاق المحكمين وعددهم (7) على كل مفردة من مفردات بطاقة تقييم المحتوى

من حيث: مدى تمثيل مفردات بطاقة تقييم المحتوى.

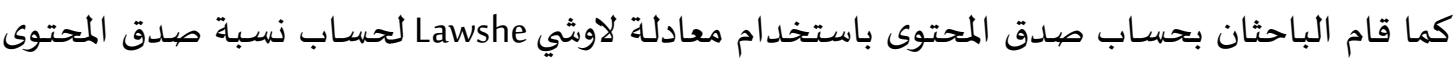

لكل مفردة من مفردات البطاقة، ويوضح الجدول الآتي نسب اتفاق المحكمين (Ratio Validity Content) (RVC)

ومعامل صدق لاوشي للبطاقة.

\begin{tabular}{|c|c|c|c|c|c|c|c|}
\hline معامل صلدق & رقمر & معامل صلدق لاوشي & المفردة & معامل صلدق لاوشي & رقمر & معامل صلدق & رقمر \\
\hline 0.71 & 34 & 1 & 23 & 0.71 & 12 & 1 & 1 \\
\hline 0.71 & 35 & 0.71 & 24 & 1 & 13 & 0.71 & 2 \\
\hline 1 & 36 & 0.71 & 25 & 1 & 14 & 0.71 & 3 \\
\hline 1 & 37 & 0.43 & 26 & 1 & 15 & 1 & 4 \\
\hline 1 & 38 & 0.71 & 27 & 0.71 & 16 & 1 & 5 \\
\hline 0.71 & 39 & 1 & 28 & 0.71 & 17 & 0.71 & 6 \\
\hline
\end{tabular}

جدول (6) متوسطات نسب الاتفاق بين المحكمين لصيدق محتوى بطاقة تقييم المحتوى (ن=7) 
المجلة العربية للطوم ونشر الأبحاث ـ مجلة العلوم التريوية والنفسية ـ المجلا الخامس ـ العدد الخامس والعثرون ـ يوليو 2021م

\begin{tabular}{|c|c|c|c|c|c|c|c|}
\hline معامل صلدق & المفردة & معامل صلدق & رقمردم & معامل صلدق & رقمثم & معامل صبدق لاوشي & رقمر \\
\hline 0.71 & 40 & 0.71 & 29 & 0.71 & 18 & 1 & 7 \\
\hline 0.43 & 41 & 0.71 & 30 & 1 & 19 & 0.71 & 8 \\
\hline 1 & 42 & 1 & 31 & 0.71 & 20 & 0.71 & 9 \\
\hline 1 & 43 & 1 & 32 & 0.71 & 21 & 0.71 & 10 \\
\hline \multirow[t]{2}{*}{0.71} & 44 & 1 & 33 & 1 & 22 & 1 & 11 \\
\hline & & & & \multicolumn{4}{|c|}{ نسبة صيدق المحتوى للمقياس ككل } \\
\hline
\end{tabular}

يتضح من الجدول (6) أن نسبة صددق المحتوى لمفردات مقياس اتجاه المعلمين قد تراوحت من (0.71: 1)

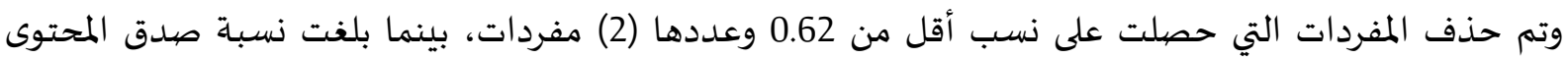

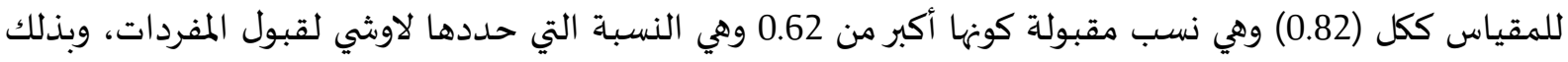
تتوافر دلالة صيدق المحتوى للمقياس من خلال نسب الاتفاق المرتفعة بين المحكمين في تقدير مدى مناسبة الفقرئ الفرات

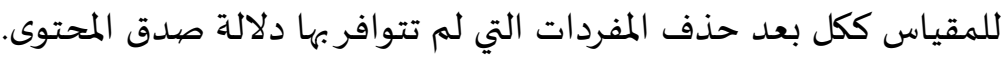
2- صدق المقارنة الطرفية:

استعان الباحثان بصدق المقارنة الطرفية مقياس اتجاه المعلمين قيد البحث في صورته الأولية عن طريق حساب قيمة متوسطات الفروق بين مجموعة مكونة من (40) من مجتمع البحث وخارج العينة الأساسية وتم ترتيب الدرجات تنازلياً وأخذ درجات أعلى 10..... كربيع أعلى ودرجات أقل 10..... كربيع أدنى وإجراء اختبار (ت) لدونه لدانلة

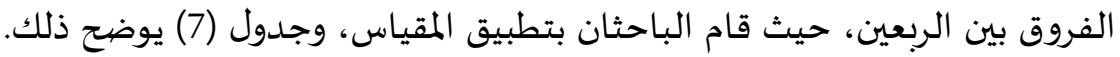
جدول (7) دلالة الفروق بين الربيع الأعلى والربيع الأدنى

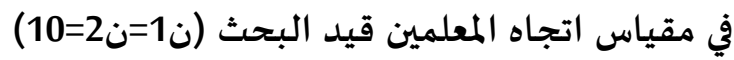

\begin{tabular}{|c|c|c|c|c|c|c|c|}
\hline \multirow{2}{*}{ مستوى الدلالة } & \multirow{2}{*}{ قيمة "ت" } & \multirow{2}{*}{ المترق بين } & \multicolumn{2}{|c|}{ الربيع الأدنى } & \multicolumn{2}{|c|}{ الربيع الأعلى } & \multirow{2}{*}{ المتغير } \\
\hline & & & $\varepsilon$ & س & $\varepsilon$ & 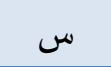 & \\
\hline 0.00 & 13.75 & 10.3 & 1.14 & 3.80 & 2.08 & 14.10 & مقياس اتجاه المعلمين \\
\hline
\end{tabular}

يتضح من جدول (22) وجود فروق دالة إحصائيا بين الربيع الأعلى والربيع الأدنى مقياس اتجاه المعلمين

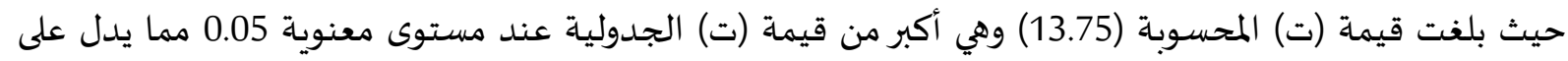

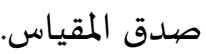
ثبات مقياس اتجاه المعلمين: ثبات التطبيق وإعادة التطبيق كما استخدم الباحثان طريقة تطبيق المقياس وإعادة تطبيقه على عينة قوامها (40) الذين تم استخدامهيم في الصدق، هذا وقد روعي وجود فاصل زمني بين التطبيقين قدره أسبوعين، وقد تم إيجاد معامل الارتباط بين

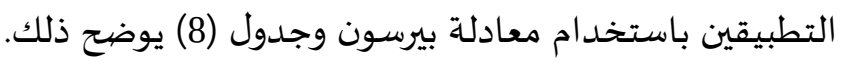


جدول(8) معامل الارتباط بين التطبيقين الأول والثاني مقياس اتجاه المعلمين (ن= 40)

\begin{tabular}{|c|c|c|c|c|c|c|}
\hline \multirow{2}{*}{ قالجيمة ر } & \multirow{2}{*}{ قيمة "ر" } & \multicolumn{2}{|c|}{ التطبيق الثاني } & \multicolumn{2}{|c|}{ التطبيق الأول } & \multirow{2}{*}{ المتغير } \\
\hline & & $\varepsilon$ & س & $\varepsilon$ & 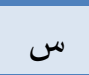 & \\
\hline 0.30 & 0.83 & 3.35 & 9.58 & 4.13 & 8.68 & مقياس اتجاه المعلمين \\
\hline
\end{tabular}

يتضح من جدول (233) وجود ارتباط دال إحصائيا بين التطبيقين الأول والثاني في مقياس اتجاه المعلمين

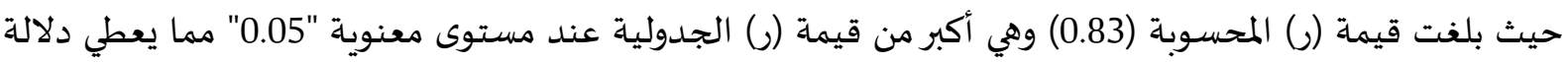
مباشرة على ثبات المقياس، وبذلك تمكنت الباحثان من التوصل إلى مقياس اتجاه المعلمين في صورته النهائية.

5. 5 إعداد مقياس اتجاه المعلمين نحو الرقمنة:

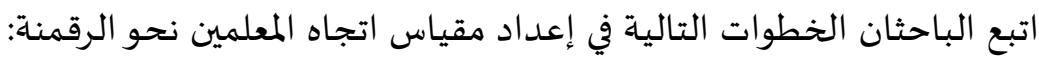

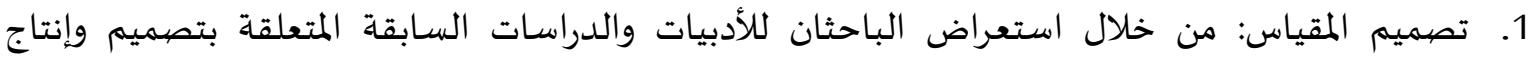

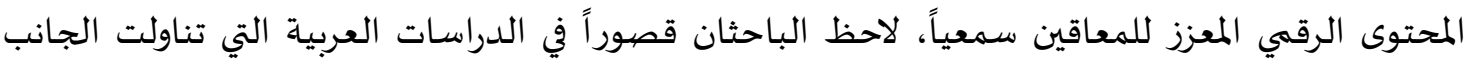

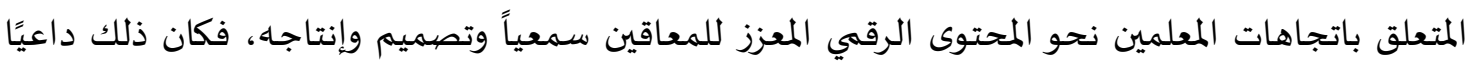

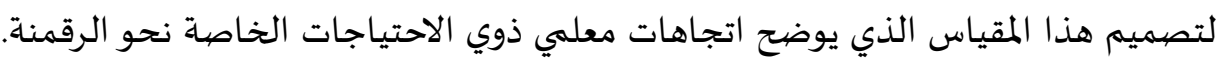

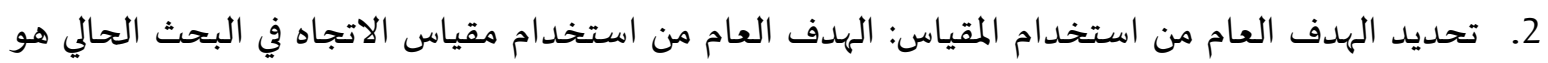

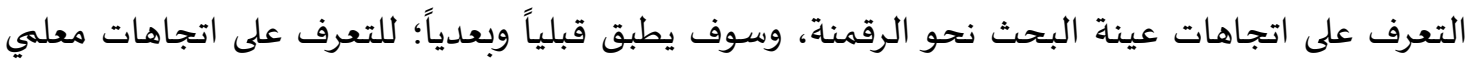
ذوي الاحتياجات الخاصة نحو الرقمنة.

3. وصف المقياس: اشتمل مقياس اتجاه معلمي ذوي الاحتياجات الخاصة نحو الرقمنة على العناصر التالية:

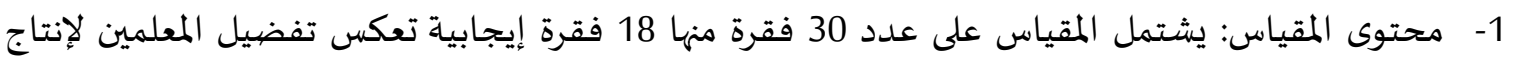

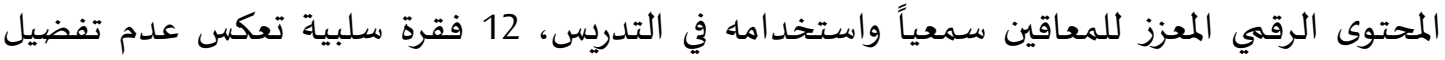

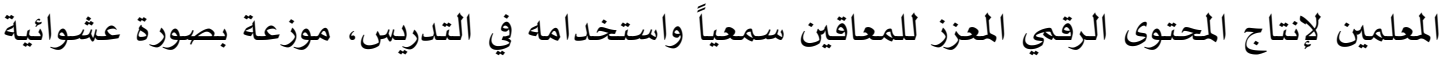

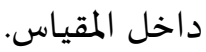
2- بدائل اختيار الاتجاه داخل المقياس: أمام كل فقرة بالمقياس سلم خماسي الدرجات حسب مقياس ليكرت

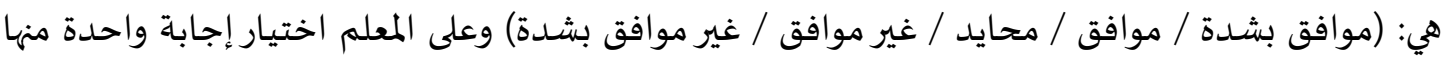
فقط لتحديد درجة موافقته على كل عبارة. 3- تعليمات المقياس: يبدأ المقياس بصفحة تمهيدية عبارة عن خطاب موجه إلى المعلم يتضيمن وصفاً

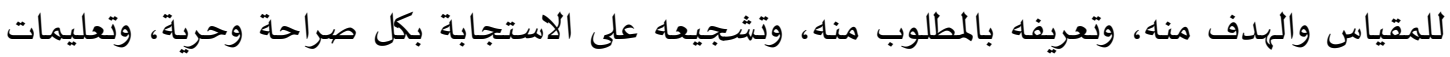
الإجابة ومثال توضيحي لكيفية الإجابة.

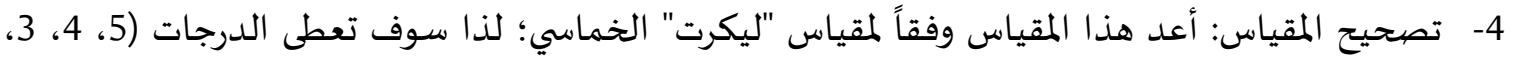

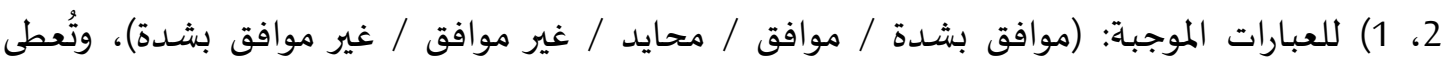

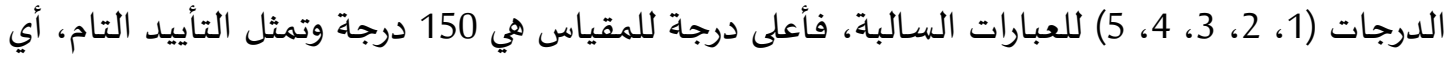
أعلى اتجاه إيجابي نحو المحتوى الرقهي المعزز للمعاقين سمعياً، وأقل درجة للمئ للمقياس هي

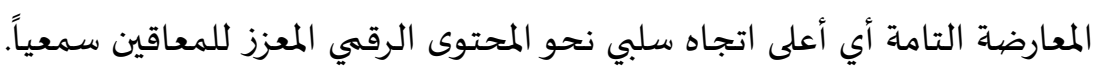
4. التحقق من صبدق المقياس: للتحقق من صبدق المقياس اتبع الباحثان الطريقتين التاليتين: 
1- التحقق من الصدق الظاهري Face Validity للمقياس؛ حيث قام بعرض المقياس في صورته الأولية على آلى

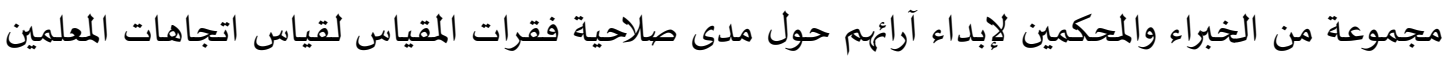

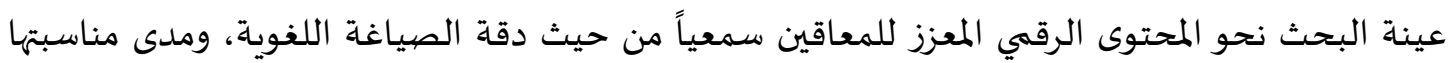

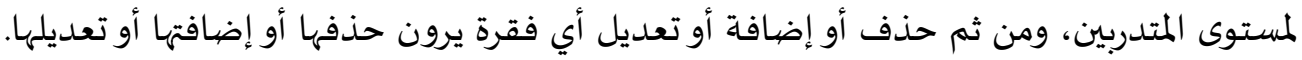

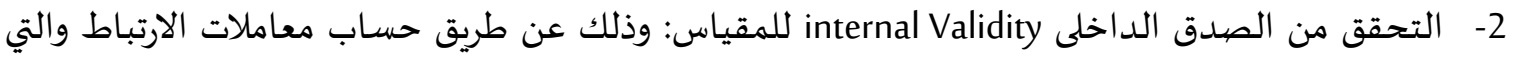
تبين أن معاملات الارتباط بين درجات كل عبارة فرعية والدرجات الكلية للاتجاه الذي تنتهي إلياه في مقياس الاتجاهات قد تراوحت بين (0.44 - 0.79) وجميعها دالة إحصائيا عند مستوى دلالة > (0.05) وبذلك دماتك

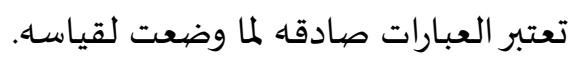

5. التوصل للصورة النهائية لمقياس اتجاهات المعلمين نحو الرقمنة: بعد التحقق من صدق وثبات مقياس

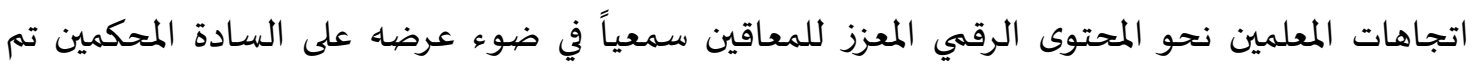
التوصل إلى الصورة النهائية للمقياس حيث تكون من •3 عبارة انقسمت إلى 15 عبارة في الاتجاه الإيجابي،

$$
\text { 6. إجراء تجربة البحث: الاتجاه السلبي }
$$

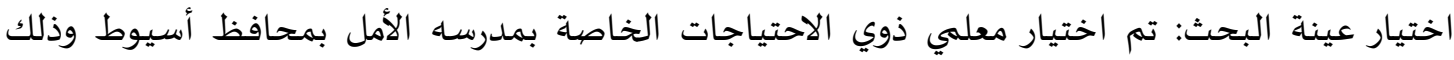

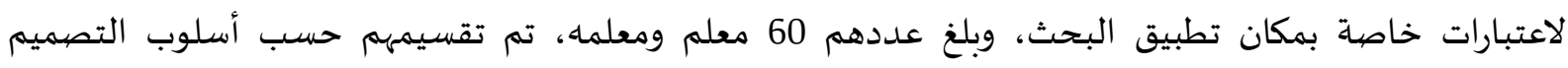

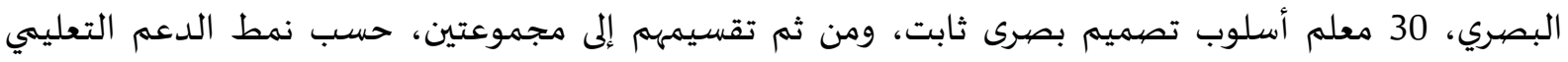

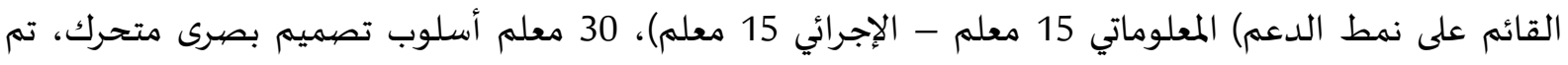

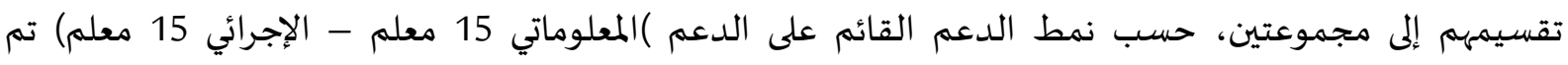

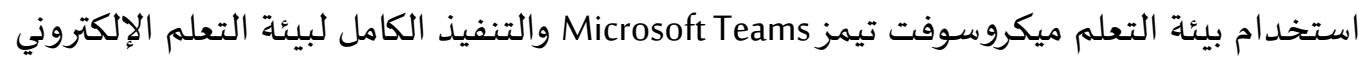

المعاملات العلمية مقياس اتجاه المعلمين: قام الباحثان بتطبيق المقياس على عينة استطلاعية قوامها (40)، وتم رصديد الدرجات تمهيداً لحساب المعاملات الإحصائية والعلمية للمقياس.

$$
\text { 1- صدق مقياس اتجاه المعلمين: }
$$

قام الباحثان بحسـاب نسب اتفاق المحكمين وعددهم (7) على كل مفردة من مفردات المقياس من حيث: مدى تمثيل مفردات مقياس اتجاه المعلمين.

\begin{tabular}{|c|c|c|c|c|c|c|c|}
\hline معامل صيدق & المفردة & معامل صلدق & المفردة & معامل صبدق & المفردة & معامل صهدق & المفردة \\
\hline 1 & 28 & 1 & 19 & 0.71 & 10 & 1 & 1 \\
\hline 0.71 & 29 & 0.43 & 20 & 0.71 & 11 & 1 & 2 \\
\hline
\end{tabular}

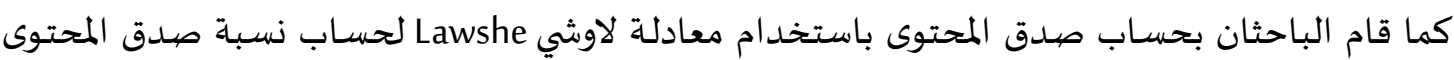
لكل مفردة من مفردات المقياس، ويوضح الجدول الآتي نسب اتفاق المحكمين (Ratio Validity Content) (RVC) ومعامل صيدق لاوشي مقياس اتجاه المعلمين.

جدول (9) متوسطات نسب الاتفاق بين المحكمين لصدئ متحتوى مقياس اتجاه المعاه المعلمين (ن=7) 
المجلة العربية للطوم ونشر الأبحاث ـ مجلة العلوم التريوية والنفسية ـ المجلا الخامس ـ العدد الخامس والعثرون ـ يوليو 2021م

\begin{tabular}{|c|c|c|c|c|c|c|c|}
\hline معامل صدلق لاوشي & المفردة & معامل صلدق & المفردة & معامل صلدق & رقمثم & معامل صبدق لاوشي & المفردة \\
\hline 1 & 30 & 1 & 21 & 1 & 12 & 0.71 & 3 \\
\hline 1 & 31 & 0.71 & 22 & 0.71 & 13 & 0.71 & 4 \\
\hline 0.43 & 32 & 0.71 & 23 & 0.71 & 14 & 0.71 & 5 \\
\hline \multirow[t]{5}{*}{0.71} & 33 & 1 & 24 & 0.43 & 15 & 1 & 6 \\
\hline & & 0.71 & 25 & 1 & 16 & 0.71 & 7 \\
\hline & & 1 & 26 & 1 & 17 & 1 & 8 \\
\hline & & 0.71 & 27 & 1 & 18 & 0.71 & 9 \\
\hline & & \multicolumn{2}{|c|}{0.82} & \multicolumn{4}{|c|}{ نسبة صدق المحتوى للمقياس ككل } \\
\hline
\end{tabular}

يتضح من الجدول (9) أن نسبة صدق المحتوى لمفردات مقياس اتجاه المعلمين قد تراوحت من (3. (0.71: 1)

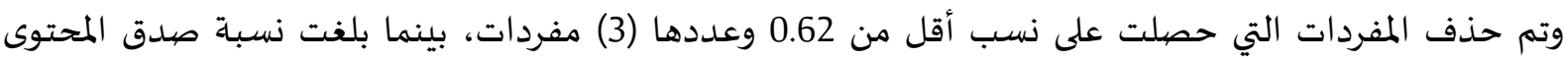

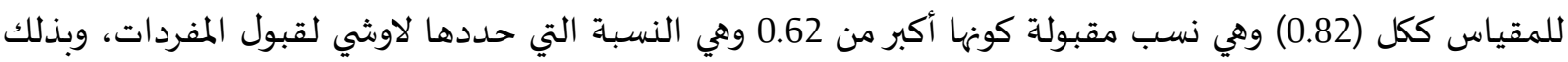

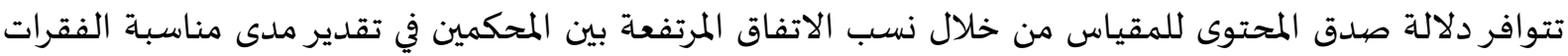

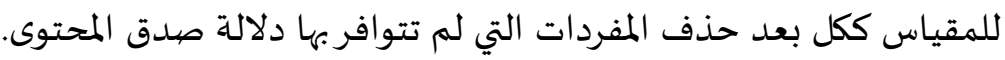

2- صديق المقارنة الطرفية:

استعان الباحثان بصدق المقارنة الطرفية مقياس اتجاه المعلمين قيد البحث في صورته الأولية عن طريق حساب قيمة متوسطات الفروق بين مجموعة مكونة من (40) من مجتمع البحث وخارج العينة الأساسية وتم ترتيب

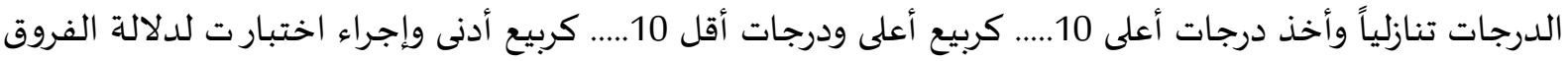
بين الربعين، حيث قام الباحثان بتطبيق المقياس، وجدول (10) يوضح ذلكاس ذلك. جدول (10) دلالة الفروق بين الربيع الأعلى والربيع الأدنى في مقياس اتجاه المعلمين قيد البحث (ن1:ن=2=10)

\begin{tabular}{|c|c|c|c|c|c|c|c|}
\hline \multirow{2}{*}{ الدلالة } & \multirow{2}{*}{ قيمة "ت" } & \multirow{2}{*}{ المترق بين } & \multicolumn{2}{|c|}{ الربيع الأدنى } & \multicolumn{2}{|c|}{ الربيع الأعلى } & \multirow{2}{*}{ المتغير } \\
\hline & & & $\varepsilon$ & س & $\varepsilon$ & س - س & \\
\hline 0.00 & 9.13 & 20.7 & 1.55 & 4.20 & 6.99 & 24.90 & مقياس اتجاه المعلمين \\
\hline
\end{tabular}

يتضح من جدول (10) وجود فروق دالة إحصائيا بين الربيع الأعلى والربيع الأدنى مقياس اتجاه المعلمين

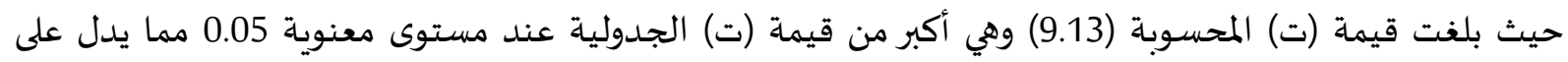
صدق المقياس.

ثبات مقياس اتجاه المعلمين: استخدم الباحثان طريقة تطبيق المقياس وإعادة تطبيقه على عينة قواهها (40) الذين تم استخداههم في في الصدق، هذا وقد روعي وجود فاصل زمني بين التطبيقين قدره أسبوعين، وقد تم إيجاد معامل الارتباط بين

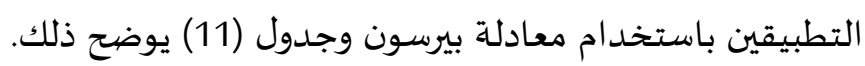

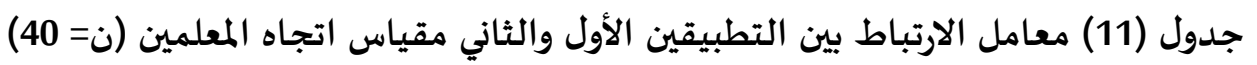

\begin{tabular}{|c|c|c|c|c|c|c|}
\hline \multirow{2}{*}{ قيمة ر الجلدولية } & \multirow{2}{*}{ قيمة "ر" } & \multicolumn{2}{|c|}{ التطبيق الثاني } & \multicolumn{2}{|c|}{ التطبيق الأول } & \multirow{2}{*}{ المتغير } \\
\hline & & $\varepsilon$ & س س & $\varepsilon$ & 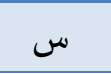 & \\
\hline 0.30 & 0.83 & 5.86 & 12.93 & 6.43 & 12.43 & مقياس اتجاه المعلمين \\
\hline
\end{tabular}


يتضح من جدول (11) وجود ارتباط دال إحصائيا بين التطبيقين الأول والثاني في مقياس اتجاه المعلمين

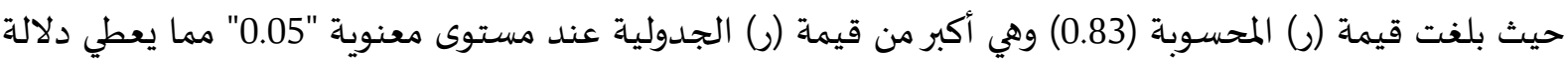
مباشرة على ثبات المقياس، وبذلك تمكن الباحثان من التوصل إلى مقياس اتجاه المعلمين في صورته النهائية.

$$
\text { تطبيق أدوات البحث قبلياً: }
$$

تم التطبيق قبلياً كل من: الاختبار التحصيلي، مقياس الاتجاه نحو الرقمنة، المديولات المرتبطة بالمحتوى، وذلك للتأكد من تجانس أفراد عينة البحث.

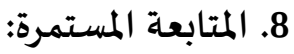

في أثناء التجربة تمت المتابعة عن طريق ميكروسوفت تيمز Microsoft Teams، وأي مشكلة يواجهها المعلمين

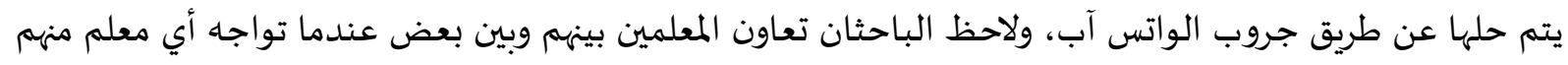

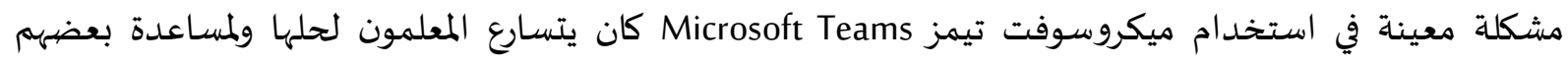
البعض، ولإبداء الآراء في أهمية ميكروسوفت تيمز Microsoft Teams وطريقة العرض للمحتوى حيث أفادوا بانهم

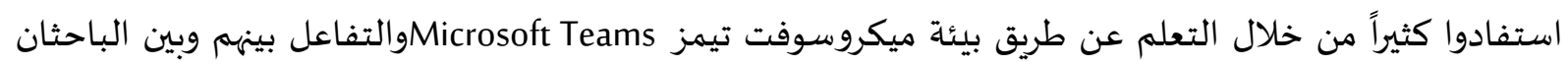

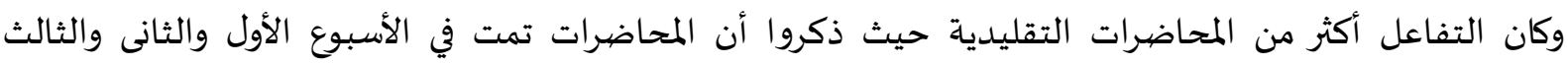

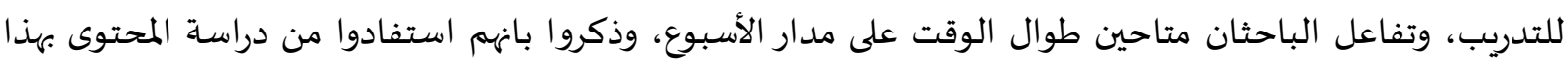

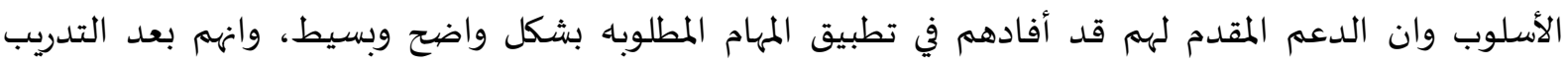
أصبحوا أكثر خبرة في إنتاج محتوى رقهى ملائم للمعاقين سمعياً.

\section{4- نتائج البحث ومناقشتها وتفسيرها}

الفرض الأول: يوجد فرق دال احصيائيا عند مستوى (0.05) نتيجة لاستخدام نمط الدعم (المعلوماتي) وأسلوب

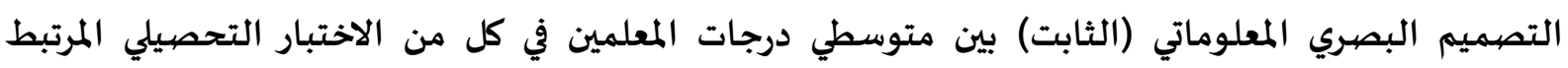

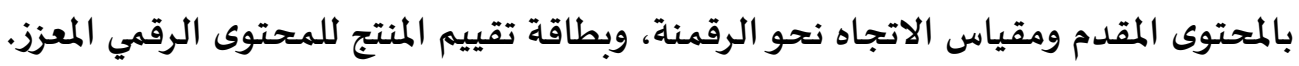

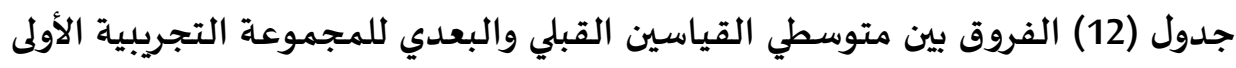

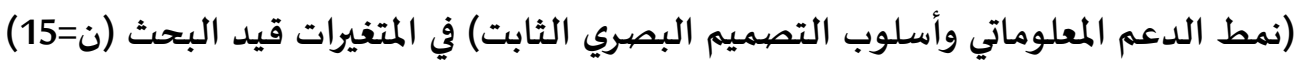

\begin{tabular}{|c|c|c|c|c|c|c|c|}
\hline \multirow{2}{*}{ 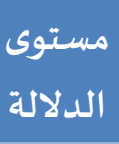 } & \multirow{2}{*}{ قالميمة ت } & \multicolumn{2}{|c|}{ القياس البعدي } & \multicolumn{2}{|c|}{ القياس القبلي } & \multirow{2}{*}{ وحدة القياس } & \multirow{2}{*}{ الاختبار } \\
\hline & & $\varepsilon$ & م & $\varepsilon$ & م & & \\
\hline 0.00 & 9.72 & 7.60 & 35.00 & 3.45 & 12.73 & 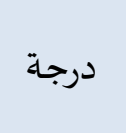 & الاختبار التحصيلي المرتبط بالمحتوى \\
\hline 0.00 & 13.42 & 15.55 & 73.00 & 3.37 & 12.93 & درجة & مقياس الاتجاه نحو الرقمنة \\
\hline 0.00 & 10.50 & 6.72 & 34.27 & 3.37 & 12.93 & 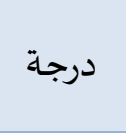 & بطاقة تقييم المنتج للمحتوى الرقهي \\
\hline
\end{tabular}

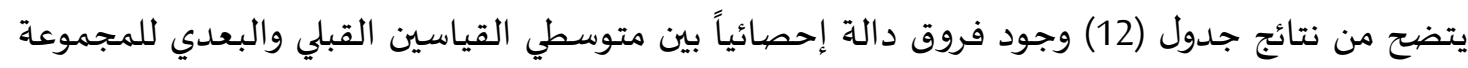

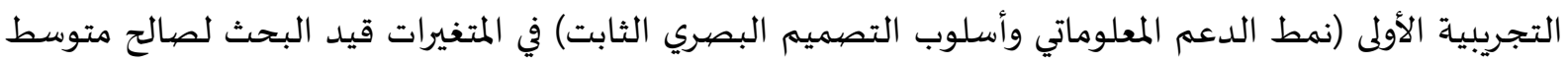


القياس البعدي حيث تراوحت قيمة "ت" المحسوبة ما بين (9.72: 13.42) وهي أكبر من قيمتها الجدولية عند مستوى

الفرض الثاني: يوجد فرق دال احصائيا عند مستوى (0.05) نتيجة لاستخدام نمط الدعم (المعلوماتي) وأسلوب

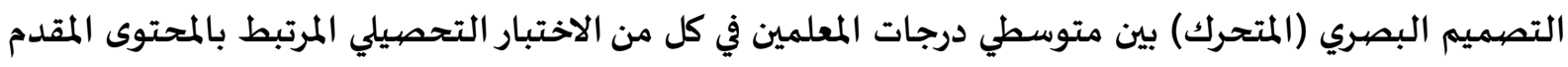

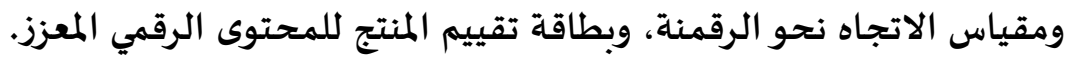

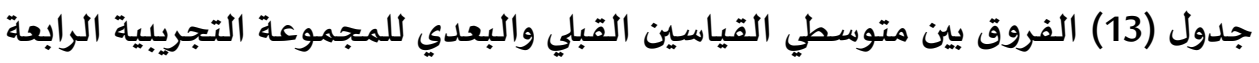

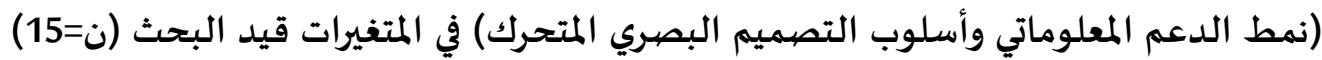

\begin{tabular}{|c|c|c|c|c|c|c|c|}
\hline 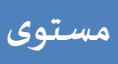 & قيمة ت & 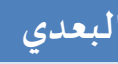 & 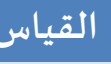 & ل لقبلي & 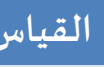 & وحدة & 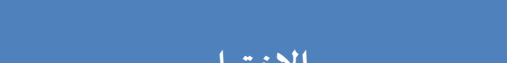 \\
\hline 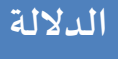 & المحسوبة & $\varepsilon$ & r & $\varepsilon$ & r & 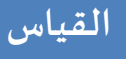 & \\
\hline 0.00 & 11.54 & 10.80 & 39.47 & 2.31 & 7.20 & درجة & الاختبار التحصيلي المرتبط بالمحتوى \\
\hline 0.00 & 12.17 & 20.97 & 79.47 & 9.44 & 12.20 & درجة & مقياس الاتجاه نحو الرقمنة \\
\hline 0.00 & 14.30 & 6.61 & 30.67 & 2.38 & 6.60 & درجة & بطاقة تقييم المنتج للمحتوى الرقمي \\
\hline
\end{tabular}

يتضح من نتائج جدول (13) وجود فروق دالة إحصائياً بين متوسطي القياسين القبلي والبعدي للمجموعة

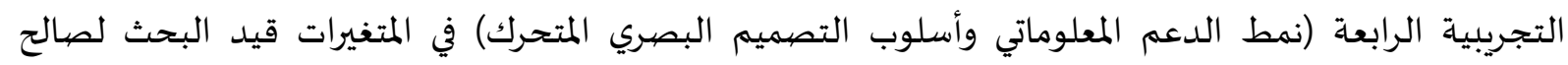
متوسط القياس البعدي حيث تراوحت قيمة "ت" المحسوبة ما بين (11.54: 14.30) وهي أكبر من قيمتها الجدولية

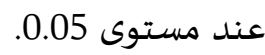

الفرض الثالث: يوجد فرق دال احصبائيا عند مستوى (0.05) نتيجة لاستخدام نمط الدعم (الإجرائي) وأسلوب

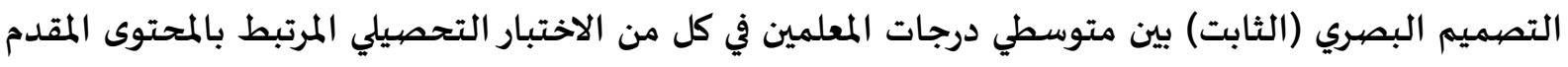

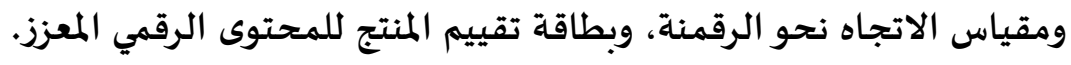

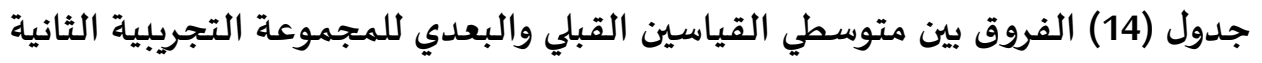

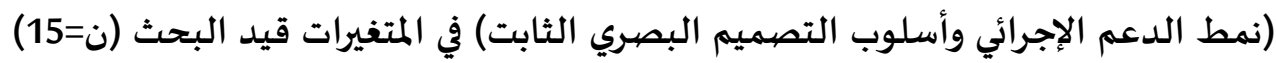

\begin{tabular}{|c|c|c|c|c|c|c|c|}
\hline \multirow{2}{*}{ مستوى } & \multirow{2}{*}{ قالميمة ت } & \multicolumn{2}{|c|}{ القياس البعدي } & \multicolumn{2}{|c|}{ القياس القبلي } & \multirow{2}{*}{ و القياس } & \multirow{2}{*}{ الاختبار } \\
\hline & & $\varepsilon$ & م & $\varepsilon$ & r & & \\
\hline 0.00 & 16.52 & 5.78 & 32.80 & 2.54 & 6.80 & درجة & الاختبار التحصيلي المرتبط بالمحتوى \\
\hline 0.00 & 10.81 & 15.53 & 64.13 & 8.58 & 12.27 & درجة & مقياس الاتجاه نحو الرقمنة \\
\hline 0.00 & 16.67 & 4.38 & 31.00 & 2.76 & 7.07 & درجة & بطاقـة تقييم المنتج للمحتوى الرقهي \\
\hline
\end{tabular}

يتضح من نتائج جدول (14) وجود فروق دالة إحصائياً بين متوسطي القياسين القبلي والبعدي للمجموعة

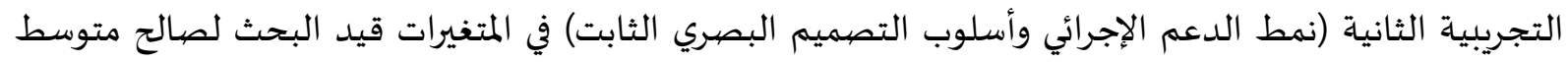
القياس البعدي حيث تراوحت قيمة "ت" المحسسوبة ما بين (10.81: 16.67) وهي أكبر من قيمتها الجدولية الميتية عند 
الفرض الرابع: يوجد فرق دال احصبائيا عند مستوى (0.05) نتيجة لاستخدام نمط الدعم (الإجرائي) وأسلوب المتيج

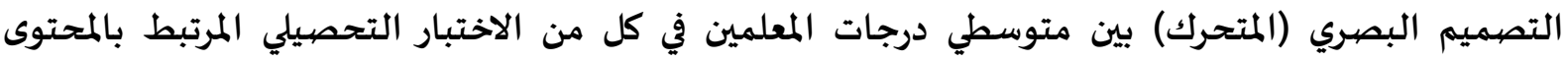

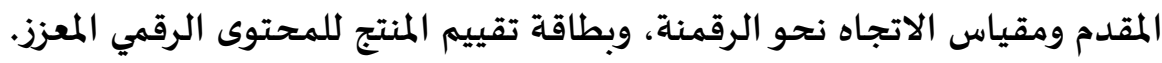

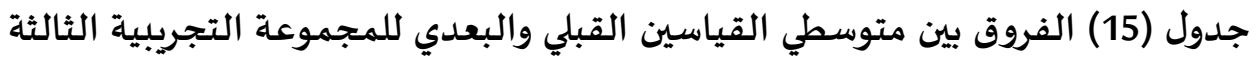

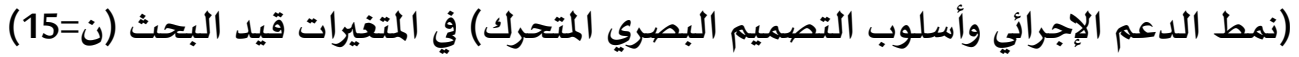

\begin{tabular}{|c|c|c|c|c|c|c|c|}
\hline \multirow{2}{*}{ 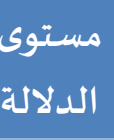 } & \multirow{2}{*}{ قاميمة ت } & \multicolumn{2}{|c|}{ القياس البعدي } & \multicolumn{2}{|c|}{ القياس القبلي } & \multirow{2}{*}{ وحدة القياس } & \multirow{2}{*}{ الاختبار } \\
\hline & & $\varepsilon$ & r & $\varepsilon$ & r & & \\
\hline 0.00 & 22.36 & 7.81 & 69.53 & 5.02 & 9.33 & 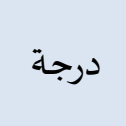 & الاختبار التحصيلي المرتبط بالمحتوى \\
\hline 0.00 & 17.92 & 22.34 & 133.20 & 6.57 & 13.87 & 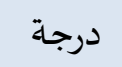 & مقياس الاتجاه نحو الرقمنة \\
\hline 0.00 & 20.76 & 1.36 & 40.13 & 5.02 & 9.33 & 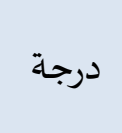 & بطاقة تقييم المنتج للمحتوى الرقهي \\
\hline
\end{tabular}

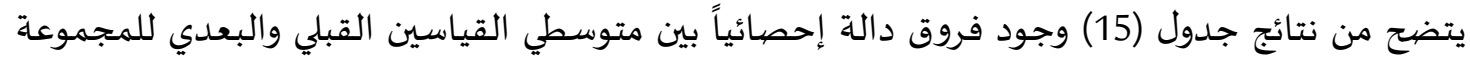

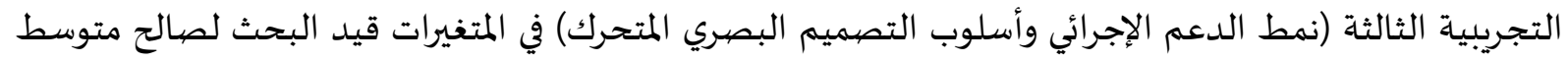

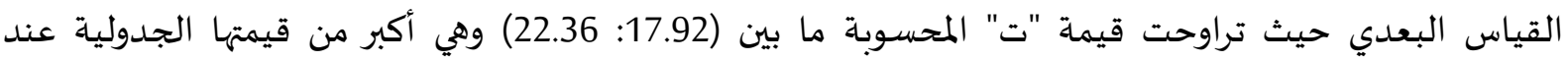

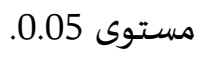
جدول (16) تحليل التباين في اتجاه واحد للفروق بين متوسطات استجابات القياسات البعدية للأربع مجموعات في متغيرات البحث (ن=60)

\begin{tabular}{|c|c|c|c|c|c|c|}
\hline مستوى الدلالة & قيمة "في & متوسط المربعات & المربحات متجوع & الحرية & مصبدر التباين & المتغيرات \\
\hline \multirow{2}{*}{0.00} & \multirow{2}{*}{65.41} & 4393.91 & 13181.73 & 3 & بين المجموعات & \multirow{2}{*}{ الاختبار التحصيلي } \\
\hline & & 67.18 & 3761.87 & 56 & داخل المجموعات & \\
\hline \multirow{2}{*}{0.00} & \multirow{2}{*}{40.93} & 14546.33 & 43638.98 & 3 & بين المجموعات & \multirow{2}{*}{ مقياس الاتجاه } \\
\hline & & 355.43 & 19903.87 & 56 & داخل المجموعات & \\
\hline \multirow{2}{*}{0.00} & \multirow{2}{*}{10.52} & 288.99 & 866.98 & 3 & بين المجموعات & \multirow{2}{*}{ بطاقة التقييم } \\
\hline & & 27.46 & 1538 & 56 & داخل المجموعات & \\
\hline
\end{tabular}

يتضح من جدول (16) وجود فروق غير دالة إحصائياً عند مستوى 0.05 بين متوسطات استجابات

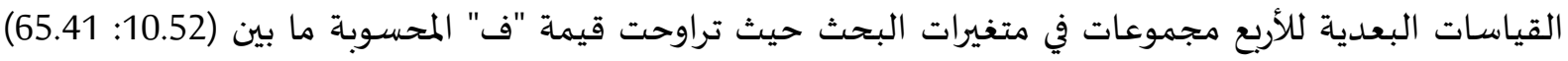

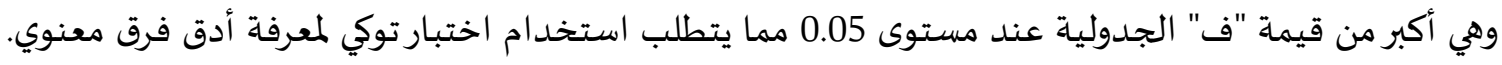


جدول (17) دلالة الفروق بين متوسطات القياسات البعدية للأربع مجموعات في الاختبار التحصيلي باستخدام اختبار TUKEY

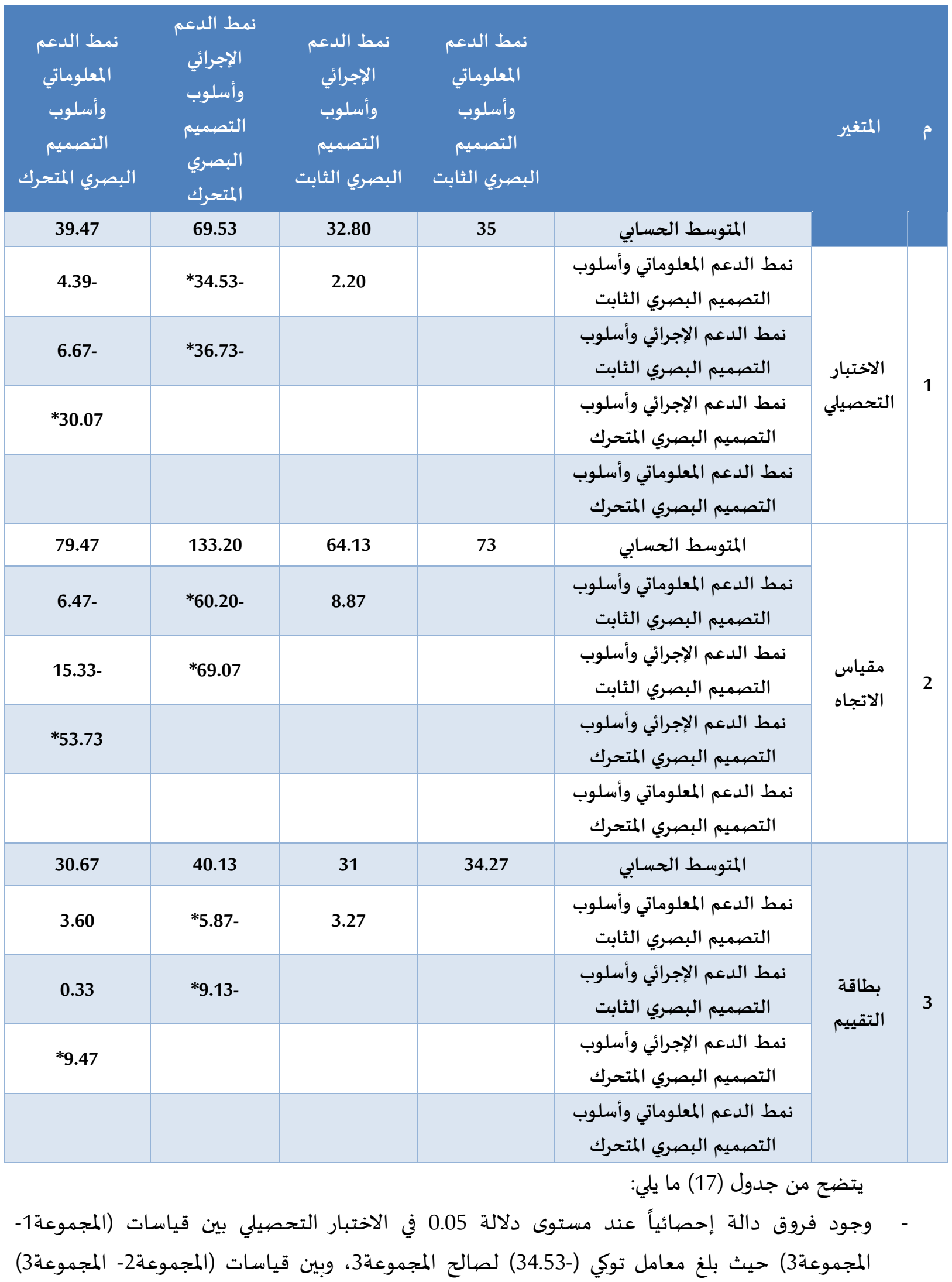


حيث بلغ معامل توكي (-36.73) لصالح المجموعة3، وبين قياسات (المجموعة3- المجموعة4) حيث بلغ معامل

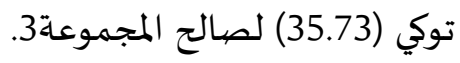
وجود فروق دالة إحصائياً عند مستوى دلالة 0.05 في مقياس الاتجاة بين قياسات (المجموعة 1- المجموعة33)

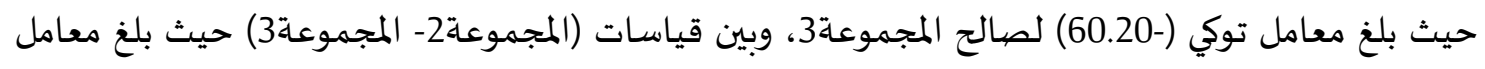

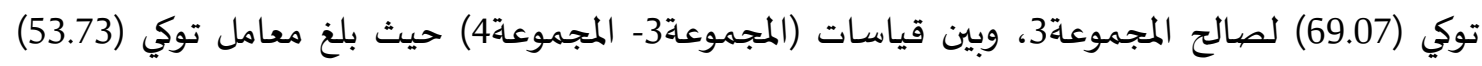
لصالح المجموعة3. وجود فروق دالة إحصائياً عند مستوى دلالة 0.05 في بطاقة التقييم بين قياسات (المجموعةة- المجموعةة3)

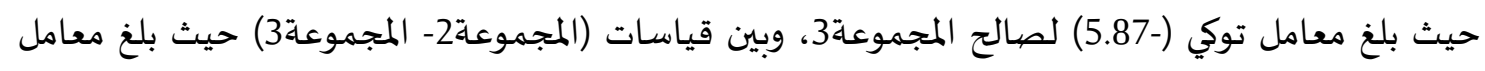

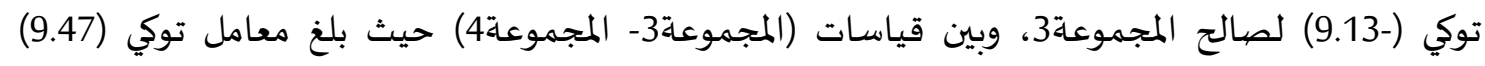
لصالح المجموعة 3. تفسير نتائج البحث: يرى الباحثان أن نتائج البحث تتفق مع نتائج كل من دراسة محمد رفعت، والسعيد عبد الرازق، وداليا

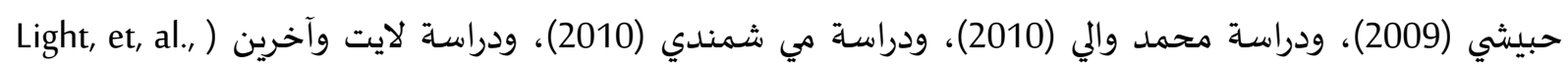

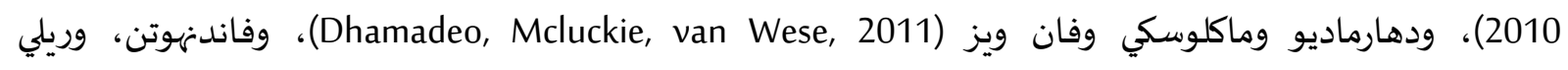

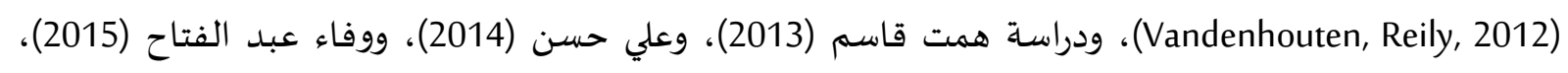

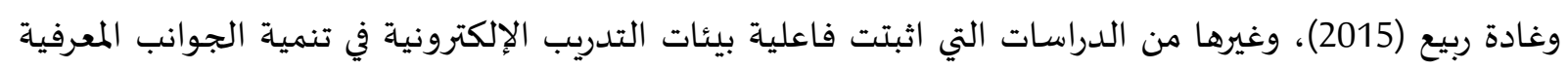
والأدائية والكفايات المختلفة للمتعلمين، وأوصت باستخدام وغيرهام استراتيجيات التعلم الإلكتروني المختلفة في العملية

كما تتفق مع دراسة كل من بينيت (Bennett, 2009)، وريتشاردسون (Richardson, 2009)، وزينب أمين (2010)، وتوماس (Thomas, 2011)، وهاميلتون (Hamilton, 2010)، وتغريد الرحيلي (2013) (2013)، ونبيل حسن (2013)، (2013)،

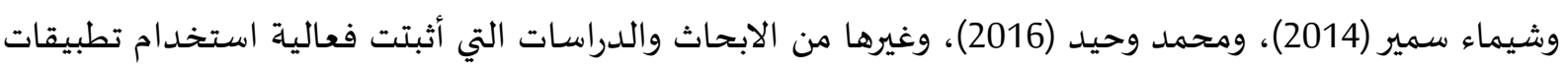

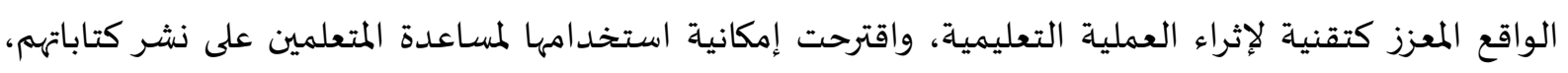

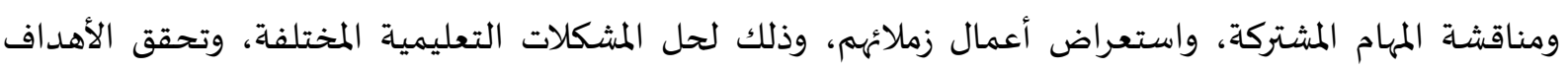

ويمكن إرجاع نتائج البحث إلى العوامل الأتية:

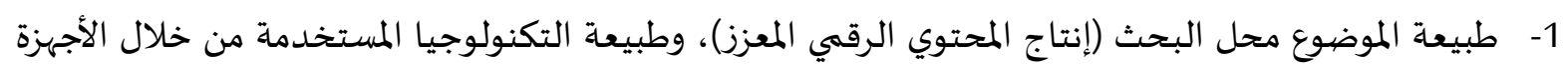
الذكية، في تقديم الموضوع للمتعلمين باستخدام استراتيجية التعلم التشاركي الإلكتروني.

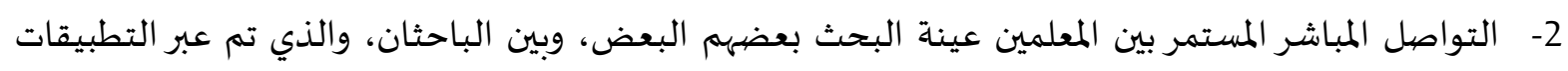

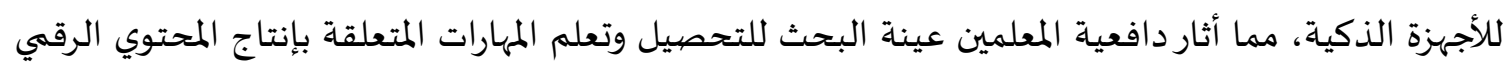
المعزز. 3- تكرار اطلاع المعلمين على المحتوى، واتاحته من خلال التطبيقات للأجهزة الذكية في منتدى نقاشي للموضوعاتً

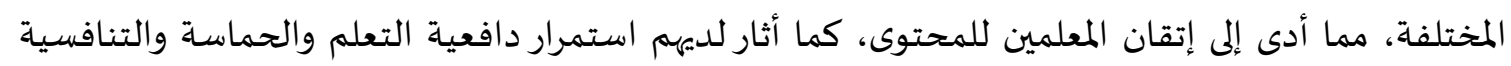

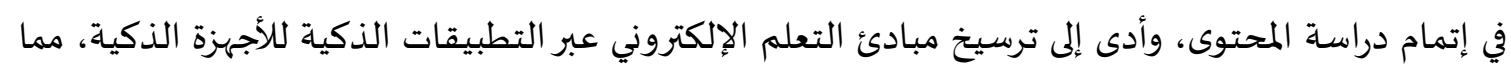

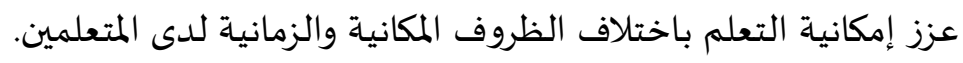


4- ما احتوته بيئة التعلم الإلكترونية من مصادر تعلم مختلفة، وما تم تداوله من انشطة عبر التطبيقات للأجهزة الذكية، ووجود اختبارات مرحلية خاصية بكل جزء من أجزاء ببيئة التعلم الإلكترونية.

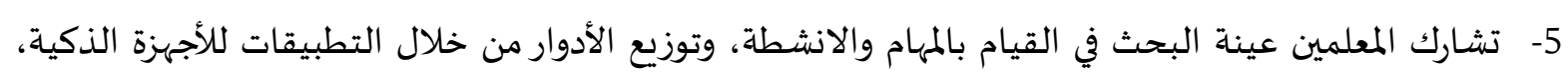
مما أدى إلى إتمام إتقان المهارات بشكل كبين.

كما يمكن تفسير نتائج البحث في ضوء نظرية التعلم الإلكتروني والتي ركزت على بعدين للتعلم كالتالي:

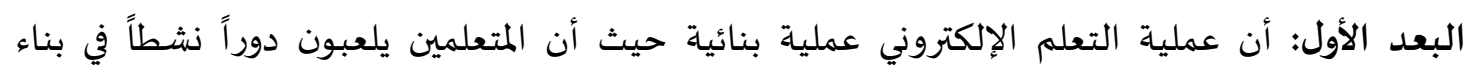

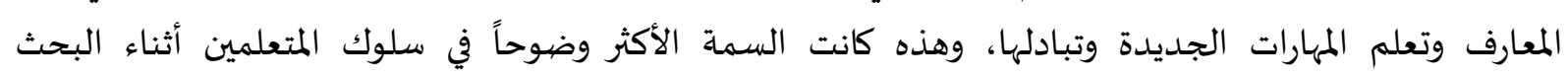
باستخدام بيئة التعلم الإلكترونية وأدواتها التشاركية.

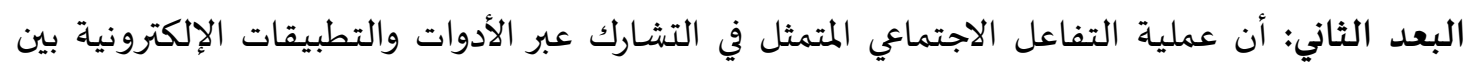

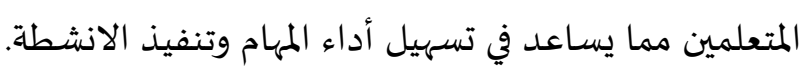

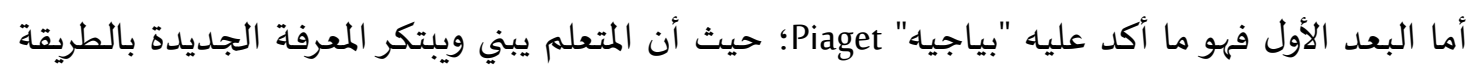

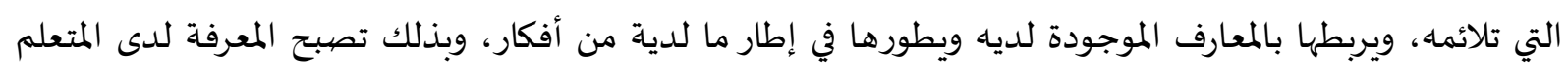

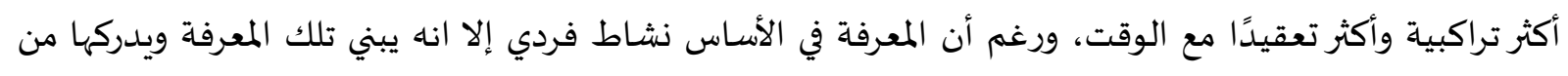
خلال التفاعل الاجتماعي مع الآخرين. وهذا ما أشارت إليه دراسة (Wei, Ismail, 2010,16) حيث تعتبر النظرية البنائية هي الإطار النظري لتعلم

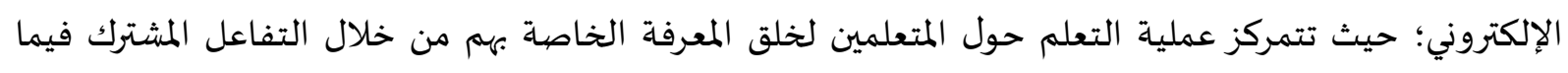

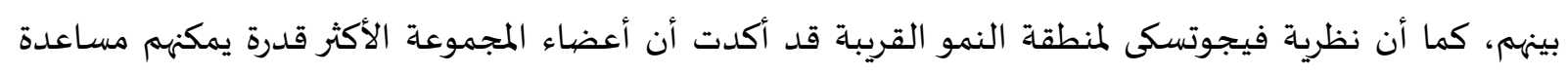

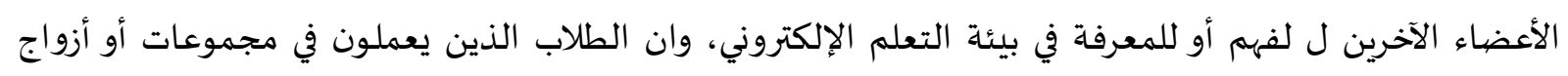
يتعلمون بشكل أفضل من الطلاب الذين يعملون بشكل فردي. كما أكدت دراسة "باروس-كاسترو" (Barros-Castro et, al., 2015, p.26) ودراسة من موكونين وآخرين ودراسة "عبده" وآخرين (Muukkonen et al., 2004, p.29)

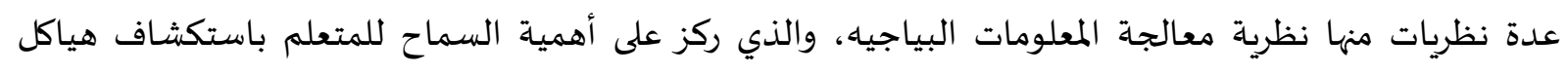

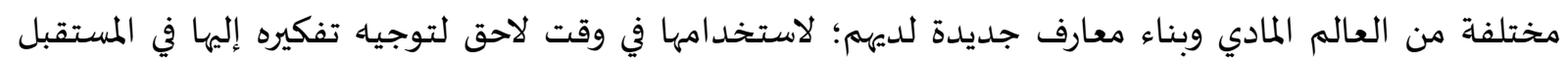

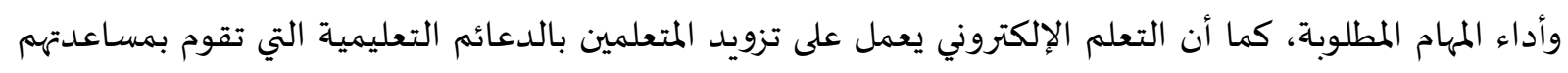

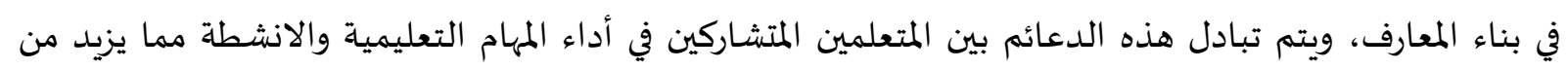
كفاءة عملية التعلم.

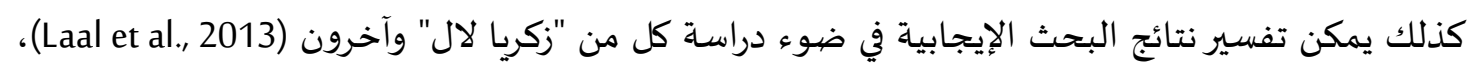

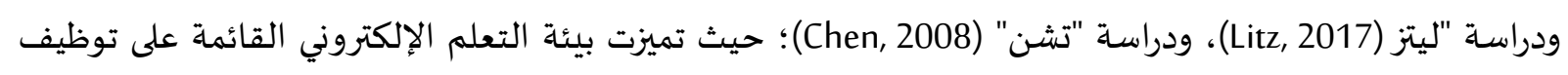

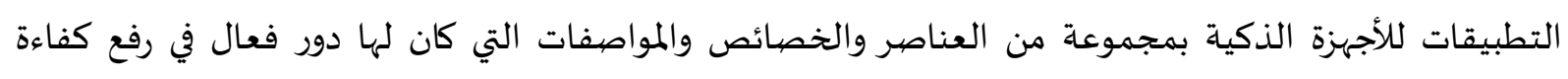
المتعلمين وتنمية معارفهم ومهاراتهم مثل:

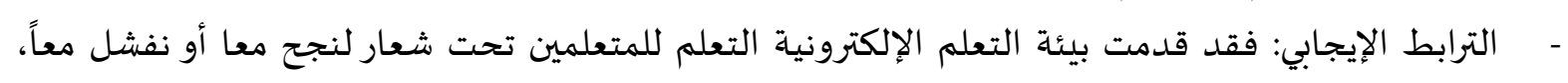

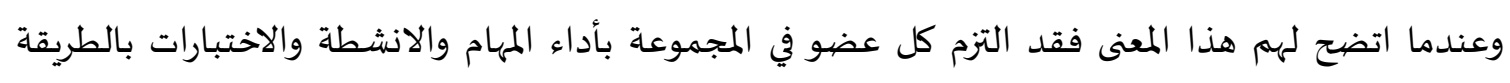
الفعالة التي تؤدي إلى نجاح كل المجموعاة. 
- التعلم الفعال: حيث قام كل عضو من أعضاء المجموعة بمساعدة زملائه وتشجيعهم على التعلم من خلال

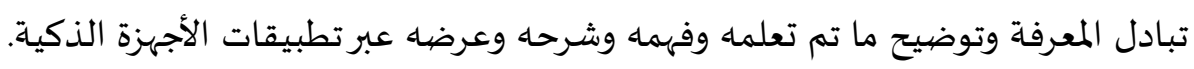

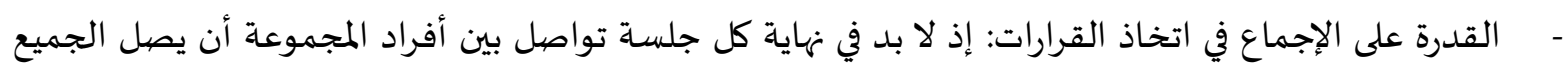

$$
\text { إلى توحيد في اتخاذ القرار. }
$$

وبذلك حققت بيئة التعلم الإلكترونية مجموعة من الأدوار الفعالة في تحسين عملية التعلم بين المتعلمين

$$
\text { تمثلت في: }
$$

- دور المتعلم حيث يعتبر الركيزة الأساسية في عملية التعلم. - مور المعلم في توجياه وتيسير عملية التعلم. - - دور التكنولوجيا في دعم وتقديم عملية التعلم.

$$
\text { التوصيات والمقترحات. }
$$

بناءً على النتائج التي تم التوصل إلهاء يوصي الباحثان ويقترحان الآتي:

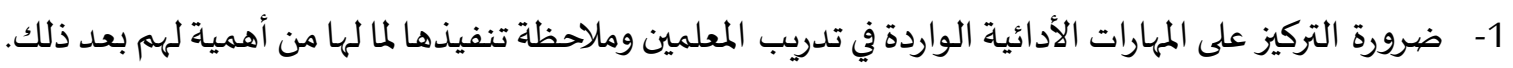

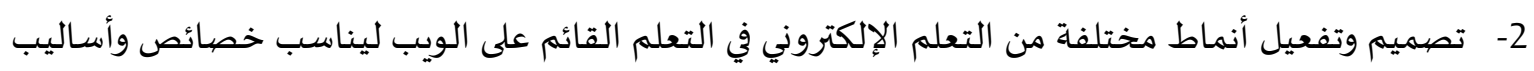

$$
\text { المتعلمين المعرفية. }
$$

3- عقد دورات تدريبية وورش عمل وندوات تدريب المعلمين على اكتساب المعرفة بأنماط التصميم البصري،

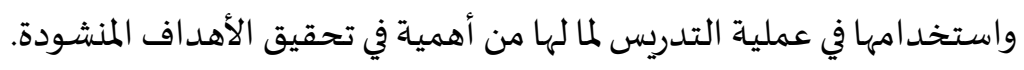

4- جذب انتباه الطلاب المعاقين سمعياً وزيادة دافعيتهم نحو التعلم وتطوير مهاراتهم مستقبلياً. 5- الاستفادة من تقنيات الشبكة العالمية بمختلف صورها في نشر المقررات الدراسية بتقنية الواقع المعزز واعطاء

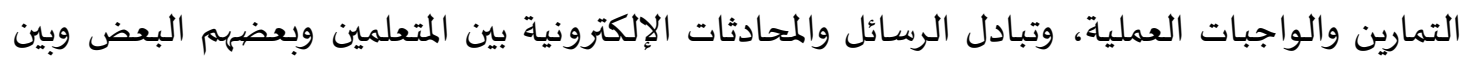

$$
\text { مدرسيهم. }
$$

6- تدربب الطلبة المعاقين سمعياً على استخدام أدوات التفاعل المناسبة في التعلم القائم على تقنيات الواقع المعزز

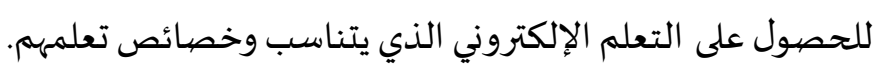

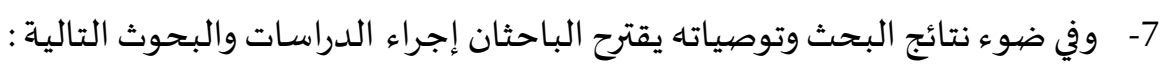

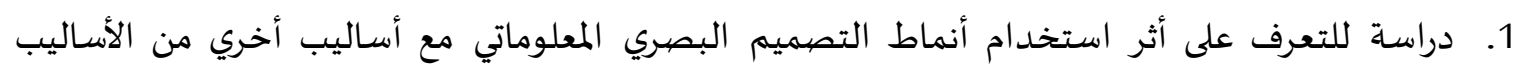
2. استخدام أنماط التصميم البصري المعلوماتي في تنمية مهارات أخري مثل مهارات التفكير ونواتج أخري من نواتج التعلم. 3. دراسة للتعرف على أثر استخدام أنماط التصيميم البصري المعلوماتي على اتجاهات طلبة المعاقين سمعيا

$$
\text { نحو المستحدثات التكنولوجية }
$$
4. إجراء مزيداً من الدراسات على مجتمعات أخري. 


\section{أولاً - مراجع باللغة العربية}

- أحمد السيد عبد الحميد مصطفى. (2006). استراتيجيات التدريس للصهم، سلسلة استراتيجيات التدريس لذوي

الحاجات الخاصة.

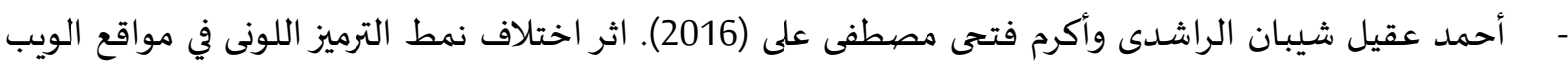

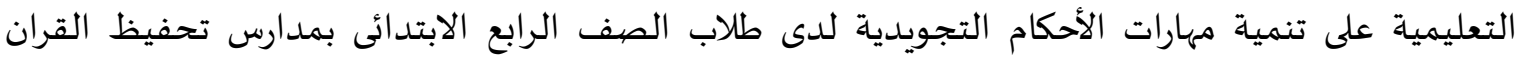

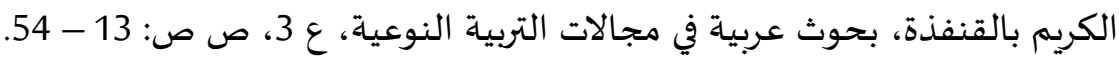

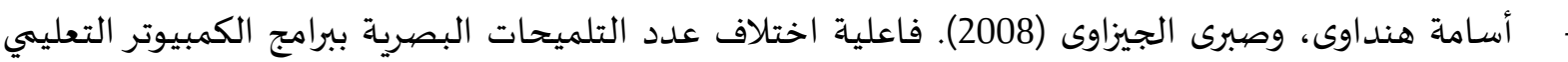

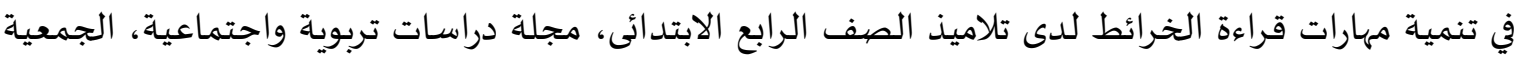

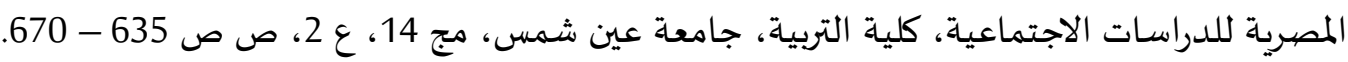

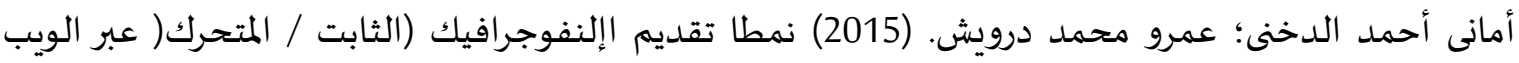

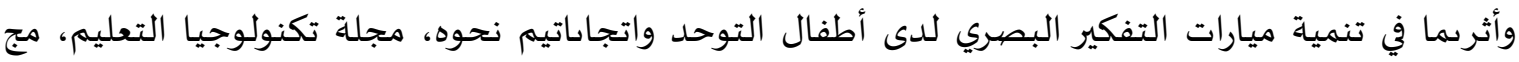

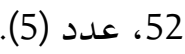

- ـ أمل إبراهيم حمادة (2017). أثر استخدام تطبيقات الواقع المعزز على الأجهزة النقالة في تنمية التحصيل

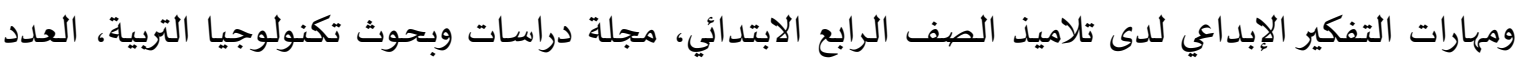

$$
\text { 34، يوليو 2017، ص } 259 \text { - } 2318 .
$$

أميرة أحمد فؤاد حسن (2013): فعالية الدمج بين المتاحف الواقعية والافتراضية على التحصيل المعرفي والتفكير الابتكاري والانطباعات لدى طلاب تكنولوجيا التعليم المستقلين والمعتمدين، رسالة دكتوراه، كلية التربية

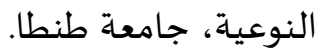

إيهاب سعد محمدي (2016). المستحدثات التكنولوجية المرتبطة بالواقع الافتراضي، مجلة التعليم الإلكتروني جامعة المنصورة، العدد التاسع عشر، أبريل 2016.

تقنية الواقع المعزز (2016). مجلة التعليم الإلكتروني - جامعاة المنصورة، العدد التاسع عشر ، أبريل 2016. جمال الخطيب (1991). التصميم التعليمي نظرية وممارسة، مجلة رسالة التربية، العدد 8، ص 115 - 132. جمال الدين إبراهيم محمود العمرجي (2017). فاعلية استخدام تقنية الواقع المعزز في تدريس التاريخ للصفي فهله الأول الثانوي على تنمية التحصيل ومهارات التفكير الرياضي والدافعية للتعلم باستخدام التقنيات لدى الطلاب،

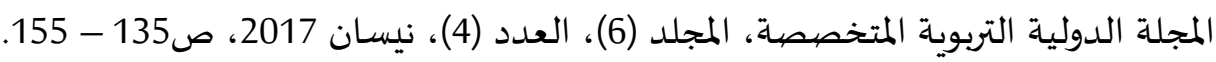
جمانة عادل خزام (2015). أسلوبا التعلم السطي والعميق وعلاقتهما بأبعاد التفكير ما وراء المعرفي، دراسة ميدانية لدى عينة من طلبة كلية التربية في جامعة البعث، رسالة ماجستير، كلية التربية، جامعة دمشق. الجوهرة على الدهاسي. (2017). تقنية الواقع المعزز في تنمية مهارات التفكير الرياضي، مجلة القراءة والمعرفة،

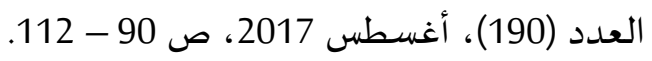

حسن حسين زيتون (2003). استراتيجيات التدريس: رؤية معاصرة لطرق التعليم والتعلم، القاهرة: عالم الكتب.

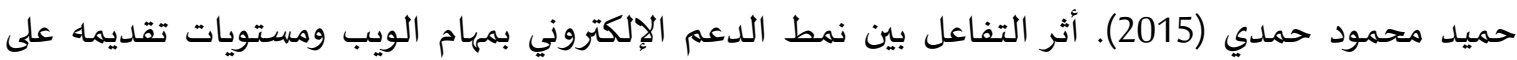

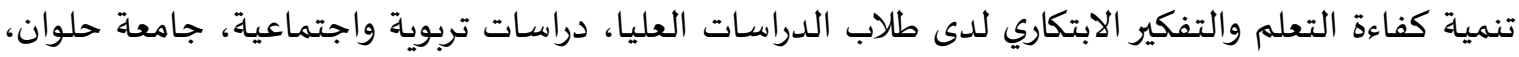

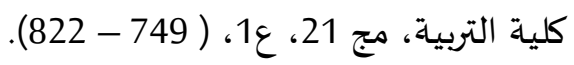


رضا ابراهيم عبد المعبود (2017): أثر برنامج تعليمي في العلوم قائم على تقنية الانفوجرافيك في اكتساب

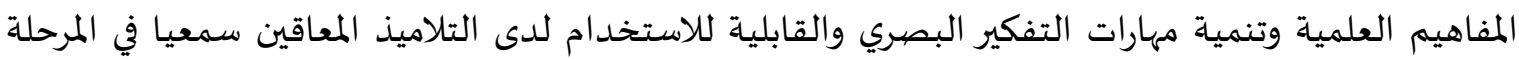

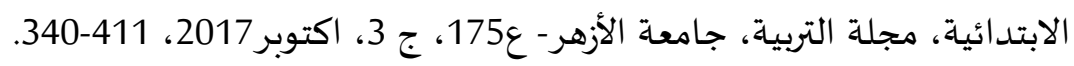

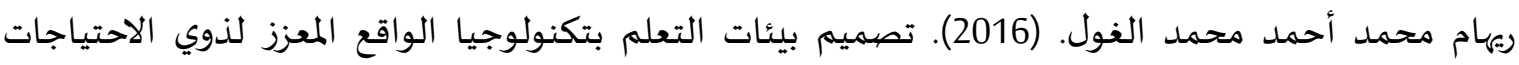

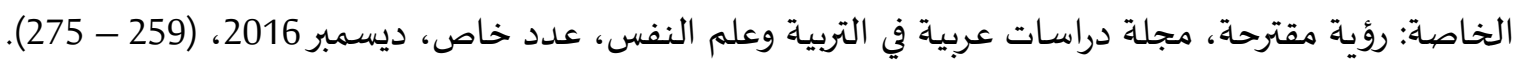
زينب حسن حامد السلامي (2008). أثر التفاعل بين نمطين من سقالات التعلم وأسلوب التعلم عند التد تصيميم

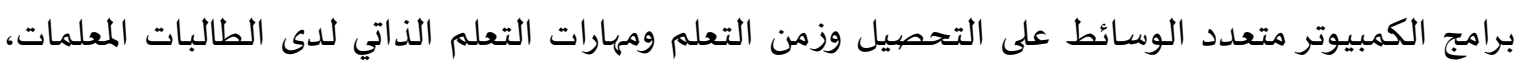

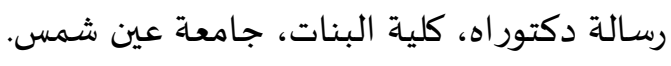
زينب حسن حامد السلامي، محمد عطية خميس (2009). معايير تصميم وتطوير برامج الكمبيوتر متعدد

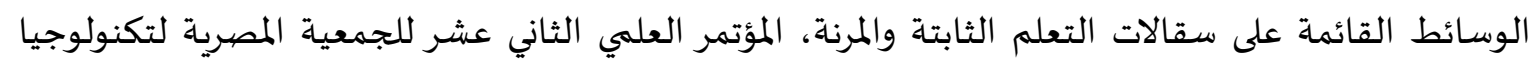

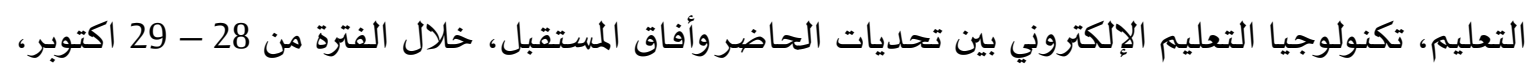
القاهرة: كلية البنات عين شمس. تكسوليا سعود محمد هذال الأكلبي (2013). أثر نمط التلميحات البصرية بالبرمجيات التعليمية متعددة الوسائط في

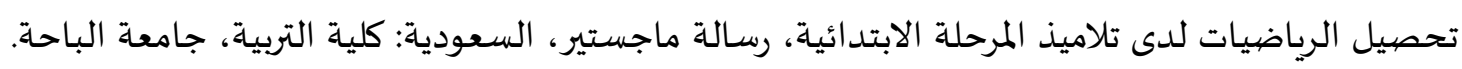

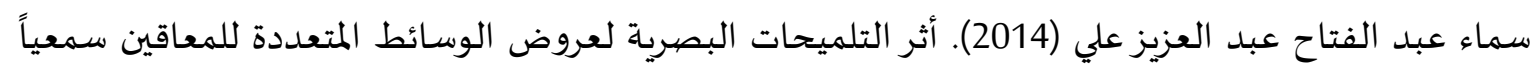

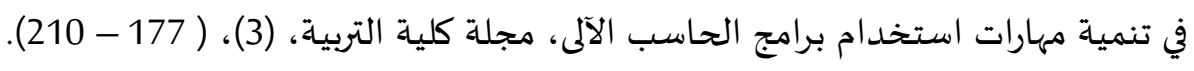

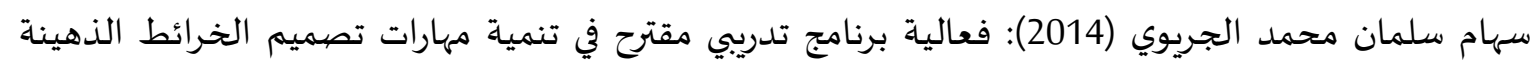

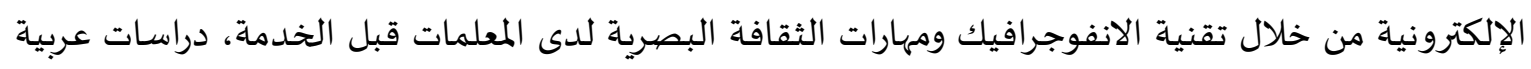

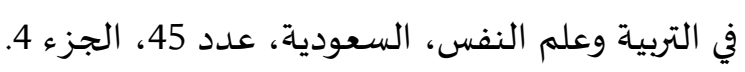

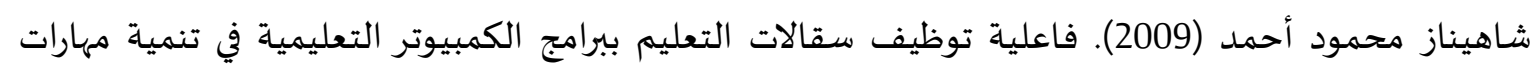

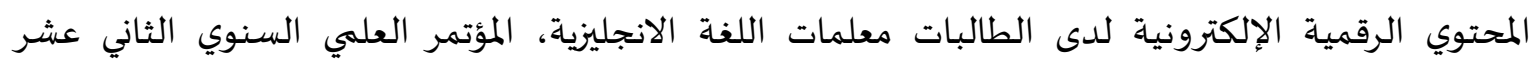

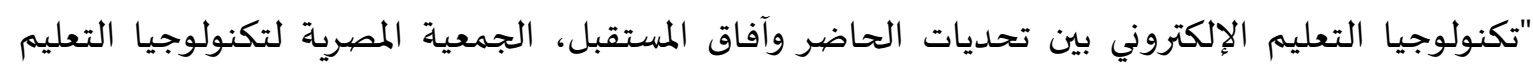
بالتعاون مع كلية البنات جامعة عين شمس، الفترة من 28 - 29 اكتوبر، 37 - 37 - 66.

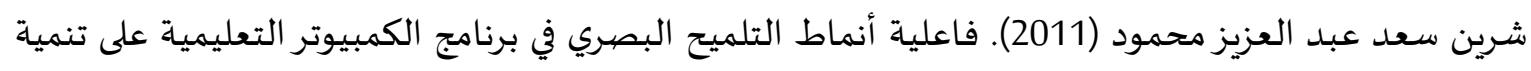

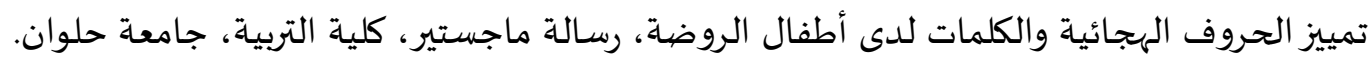

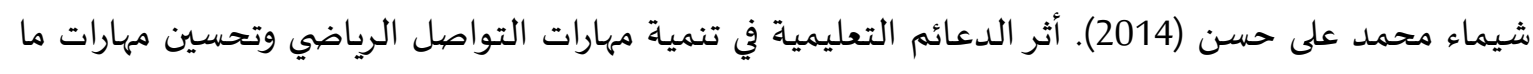

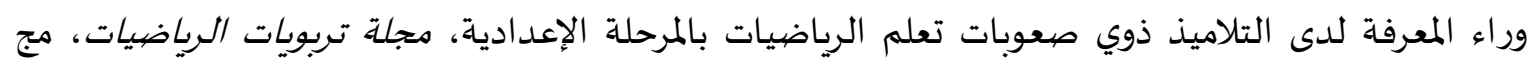
(228-155)، (17)

شيماء يوسف صوفي يوسف (2006). أثر اختلاف مستويات التوجيه وأساليب تقديماه في برامج الكمبيوتر

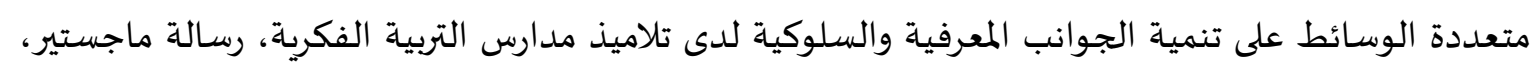
كلية البنات، جامعة عين شمس. طارق عبد السلام عبد الحليم (2010). أثر التفاعل بين مستويات المساعدة (الموجزة والمتوسطة والتفصيلية)

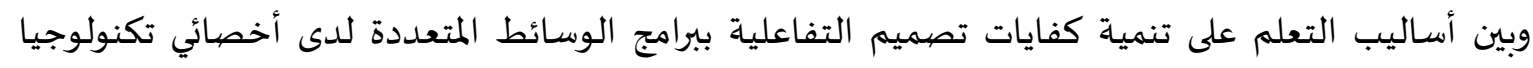

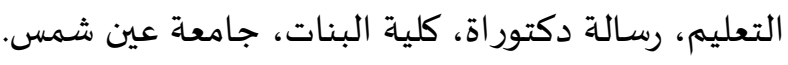


عادل عبد الرحمن، عبير عادل السيد، إيناس عبد الرؤوف سيد (2016). دراسة تحليلية للانفوجرافيك ودوره في العملية التعليمية في سياق الصياغات التشكيلية للنص، مجلة بحوث في التربية الفنية والفنون، كلية التربية الفنية، جامعة حلوان.

عبد العال عبد الله السيد (2012). تطور الفصيول الإلكترونية وإدارتها وتنمية مهارات تطبيق الانشطة

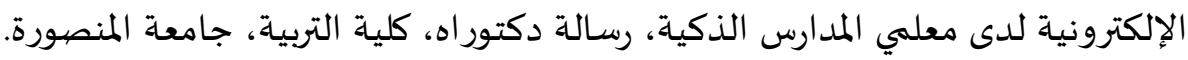
عبد العال عبد الله السيد (2016). المنصات التعليمية الإلكترونية Edmodo رؤية مستقبلية لبيئات التعلم

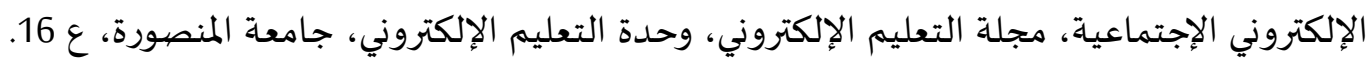

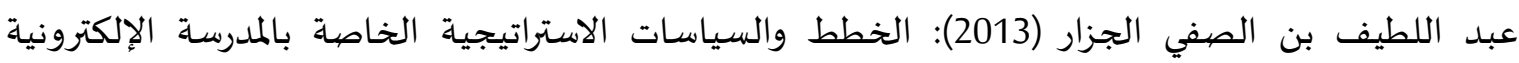

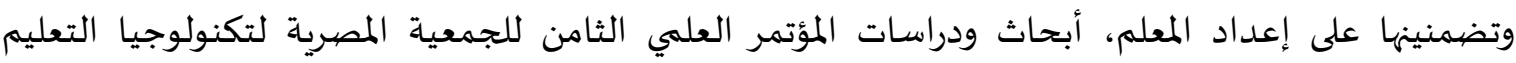
بعنوان المدرسة الإلكترونية، كلية البنات، جامعاة عين شمس، إعلى القاهرة.

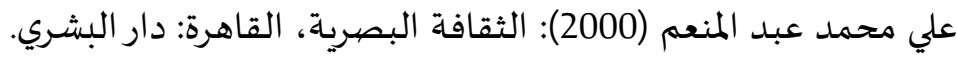

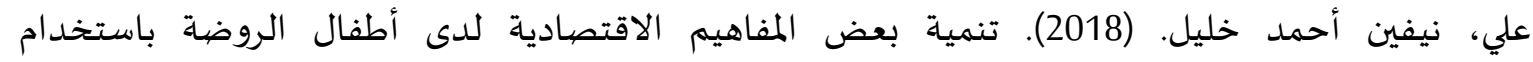

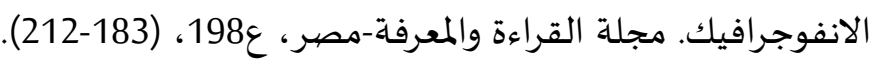
عمرو محمد محمد درويش، أماني أحمد محمد الدخني (2015): نمطا تقديم الانفوجرافيك (الثابت/ المتحرك)

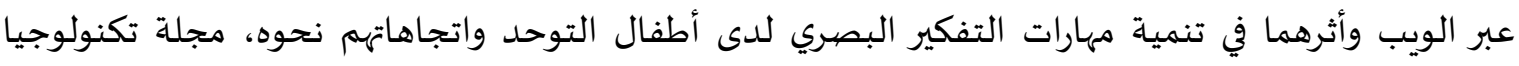

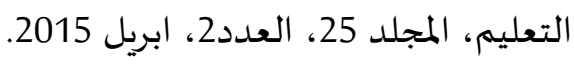
ماريان ميلاد منصور (2015): أثر استخدام تقنية الانفوجرافيك القائم على نموذج أبعاد التعلم لمارزانو على الميلى

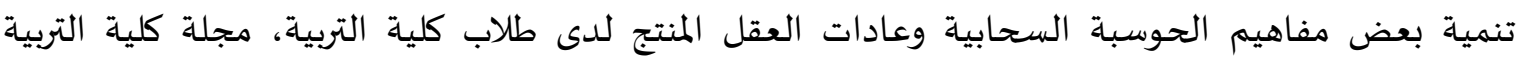

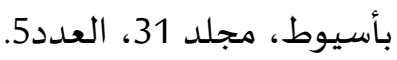
ماهر محمد صالح زنقور (2015). برمجية تفاعلية قائمة على التلميح البصري وأثرها في تنمية مهارات التفكير

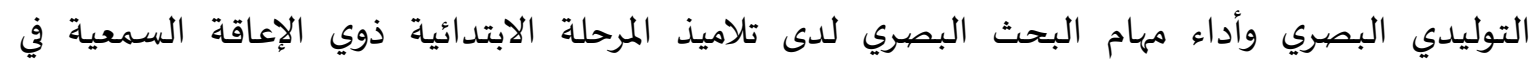

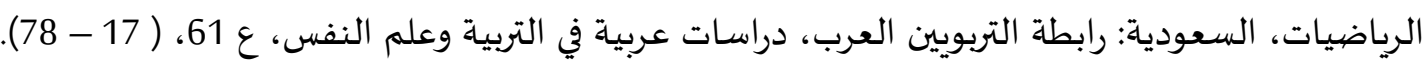

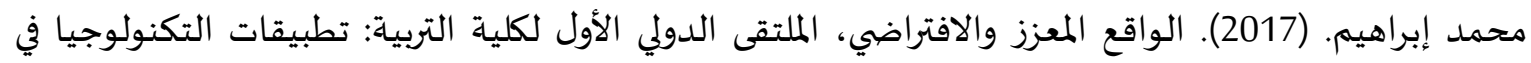

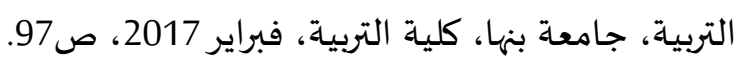
محمد عطية خميس (2000). منظومة تكنولوجيا التعليم في المدارس والجامعات والواقع والمأمول، مجلة

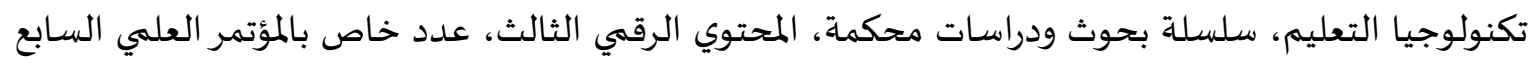
للجمعية المصرية لتكنولوجيا التعليم.

محمد عطية خميس (2007) الكمبيوتر التعليمي وتكنولوجيا الوسائط المتعددة، القاهرة: مكتبة دار السحاب.

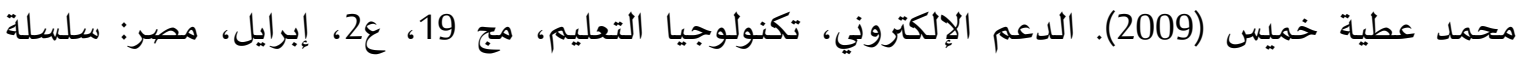
دراسات وبحوث محكمة.

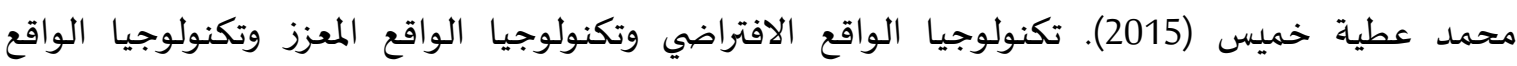
المخلوط، مجلة تكنولوجيا التعليم - سلسلة دراسات وبحوث محكماة، القاهرة، الجمعية المصرية لتكنولوجيا.

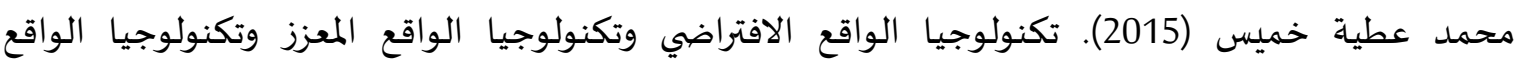

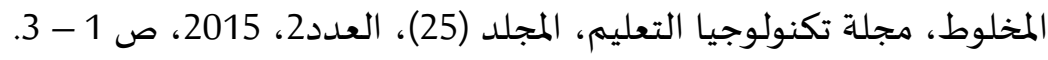


محمد عطيه خميس (2013): النظرية والبحث التربوي في تكنولوجيا التعليم، القاهرة: دار السحاب للطباعة والنشر والتوزيع. مجعمد.

ممدوح سالم الفقى (2014). أثر التفاعل بين نمطين من سقالات التعلم والأسلوب المعرفي على تحصيل

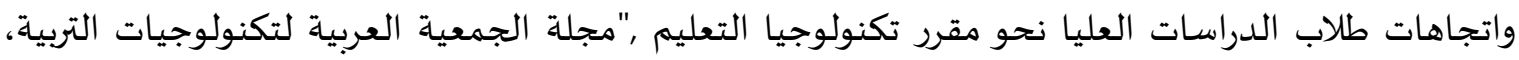
عدد (22). مها عبد المنعم محمد الحسيني (2014). أثر استخدام تقنية الواقع المعزز في وحدة من مقرر الحاسب الآلي في تحصيل واتجاه طالبات المرحلة الثانوية، رسالة ماجستير، كلية التربية، جامعة أم القرى، المملكة العربية السعودية. نرمين محمد إبراهيم نصر؛ هدى مبارك سمان مبارك. (2017). أثر تطبيق الواقع المعزز في تنمية المهارات الأساسية لتصميم مواقع الويب بلغة HTML5 على طالبات جامعة الطائف واتجاهاتهن نحوه، مجلة دراسات

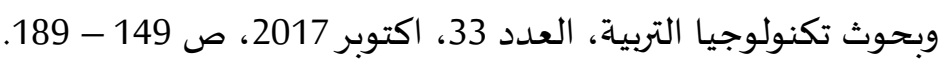

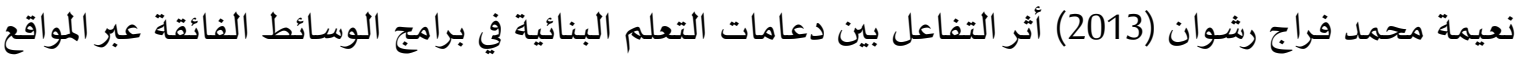
الإلكترونية والأسلوب المعرفي في تنمية بعض جواجية انب التعلم لدى طلاب كلية التربية بالعريش. مجلة القراءة

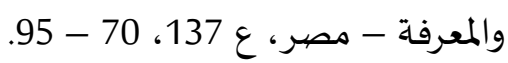
نورياة عمر أحمد (2013). الاتجاهات المعاصرة في تعليم وتأهيل الأشخاص ذوري الإعاقة السمعية، المؤتمر العلمي

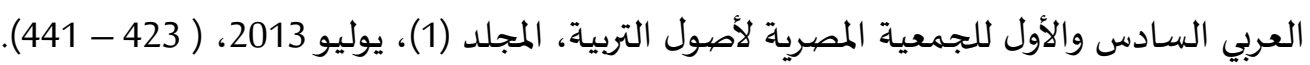

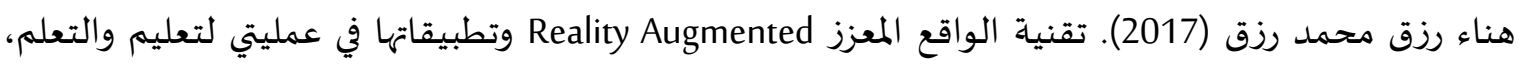

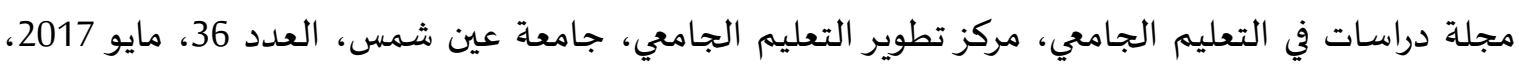
ص 570 - 581. - الواقع المعزز Augmented Reality. (2019). المركز القومي للتعلم الإلكتروني - مركز الخدمات الإلكترونية والمعرفية - المجلس الأعلى للجامعات، العدد الأول، مارس 2019. وليد يوسف محمد (2014). أثر استخدام دعامات التعلم العامة والموجهة في بيئة شبكات الويب الاجتماعية التعليمية في تنمية مهارات التخطيط للبحوث الإجرائية لدى طلاب الدراسات العليا وتنمية اتجاهاتهم نحماته

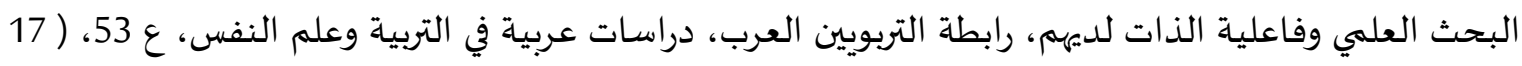
.(100-

\section{ثانياً- مراجع باللغة الانجلينية:}

- A Devplder, I van Braak, J. tondeur (2012). Supporting self-regulated learning in computer-based learning environments: systematic review of effects of scaffolding in the domain of science, education Journal of Computer Assisted Learning, 28 (6), 557-573.

- Chen C. H. (2014). An adaptive scaffolding e-learning system for middle school students' physics learning. Australasian Journal of Educational Technology, 30 (3).

- Damyanov, Nikolay Tsankov ،(2018).The Role of Infographics for the Development of Skills for Cognitive Modeling in Education South-West University ،ijET Volume 13, Number 1, Jan 22, 
2018 ISSN 1863-0383 Publisher: International Journal of Emerging Technology in Learning, Kassel, Germany.

- Dunlap, J. C., \& Lowenthal, P. R. (2016). Situational qualities exhibited by exceptional presenters. ECAR Research Bulletin. Boulder, CO: EDUCAUSE Center for Applied Research.

- Gebre, E. H., \& Polman, J. L. (2015). Developing young adults' representational competence through infographic-based science news reporting. International Journal of Science Education, 38(18), 26672687. doi: 10.1080/09500693.2016.1258129.

- Lamb, Annette;Johnson,(2011) Computer Programming for 21st Century Learners Larry Teacher Librarian; Apr 2011; 38, 4; ProQuest Central pg. 64.

- McLoughlin, C. \& LOCH, B. (2013). Scaffolding conceptual learning in mathematics with technology enhanced pedagogy a preliminary evaluation of student engagement with screencasts. In J. herrington, A. Couros \& V. Irvine (Eds.), Proceedings of EdMedia: World Conference on Educational Media and Technology, 259-265.

- Mcloughlin, C. (2002). Learner support in distance \& networked learning environment: ten dimensions for successful design-distance education, vol. 23, no. 2, pp. 149-162.

- Molenaar, I., Chiu, M., Sleegers, P. \& Boxtel Carla Van (2011): Scaffolding of Small Groups' Metacognitive Activities With An Avatar Computer-Supported Collaborative Learning, International Journal of Computer-Supported Collaborative Learning, Vol. 6, No. 4.

- Nill, A., Aalberts, R. J., Li, H., \& Schibrowsky, J. (2010). New telecommunication technologies, big data, and online behavioral advertising: Do we need an ethical analysis? In A. Nill (Ed.), Handbook on ethics and

- Nwosu B. O \& Azih, N. (2011). Effects Of Instructional Scaffolding On The Achievement Of Male And Female Students In Financial Accounting In Secondary School In Abakaliki Urabn Of Ebonyi State, Nigeria Current Research Journal Of Social Sciences, Vol. 3, No. 2, pp. 66-70.

- Quintana, Chris; Krajcik, Joseph; Soloway, Scaffolding Design Guidelines for Learner-Centered Software Environments. PUB DATE 2002-04-00 NOTE 26p.; Paper presented at the Annual Meeting of the American Educational Research Association (New Orleans, LA.

- Teo, T. (2011). Technology Acceptance in Education Research and Issues, Sense Publishers.

- The Turkish Online Journal of Educational Technology - July 2016, volume 15 issue 3- The Turkish Online Journal of Educational Technology 98 Infographics for Educational Purposes: Their Structure, Properties and Reader Approaches.

- Tsakanikos, E. (2006). Associative learning and perceptual style: Are associated events perceived analytically or as a whole? Personality and Individual Differences, 40, 579-586.

- Versov, N. (2004): Zone of proximal fevelopment (ZPD): the hidden dimension Language as culture, Social \& educational Journal, Vol. 1. 
- Wang, Xin (2012): Teacher-Student Relationship and Quality Education in college and University English Teaching, Higher Education of Social Science, 3 (2).

- Wong, N. \& Lim. W. (2003). Cross Cultural Validation of Models of Approaches to Learning, Educational Psychology, Vol. 16, No. 3, pp. 305-321. 